\title{
Mobile Phone Payments and Demand for Cash: The Case of Tanzania
}

\author{
Camillus A. Kombe, Nicas Yabu, Dominic L. Mwita, Gloria E. Mbiha \\ Research Department, Bank of Tanzania, Dar es Salaam, Tanzania \\ Email: cakombe@bot.go.tz,nyabu@bot.go.tz,dlmwita@bot.go.tz,gembiha@bot.go.tz
}

How to cite this paper: Kombe, C. A., Yabu, N., Mwita, D. L., \& Mbiha, G. E. (2020). Mobile Phone Payments and Demand for Cash: The Case of Tanzania. American Journal of Industrial and Business Management, 10, 1505-1573.

https://doi.org/10.4236/ajibm.2020.108099

Received: July 23, 2020

Accepted: August 28, 2020

Published: August 31, 2020

Copyright $\odot 2020$ by author(s) and Scientific Research Publishing Inc. This work is licensed under the Creative Commons Attribution International License (CC BY 4.0).

http://creativecommons.org/licenses/by/4.0/

(c) (i) Open Access

\begin{abstract}
This paper examines recent developments in mobile phone transactions in Tanzania, the extent of its adoption by the general public and motivation for its usage. It also explores how development in mobile phone transactions has affected the demand for cash holdings including its components (denominations) using cointegration approach supplemented by survey. Empirical estimation of Vector Error Correction Model (VECM) of demand for cash using Johansen's procedure provides no evidence of reduced cash usage driven by proliferation of mobile money transactions. Meanwhile, survey evidence has shown that, in Tanzania, mobile phone transactions have progressively gained pace over the recent years and is now the most used method of payment after cash. This trend is driven by harnessing of underlying financial regulations and platforms, acceptance of this method of payment, security for not carrying cash and simplicity in terms of speed and outreach among the counterparties. The paper concludes that the use of mobile phone money services creates additional pressure on income velocity of money, with potential impact on prices. Under the current quantity based monetary policy framework, this calls for ensuring that monetary policy formulation takes into consideration of this novel development.
\end{abstract}

\section{Keywords}

Mobile Money, Cash Demand, Cointegration, Monetary Policy, Vector Error Correction Model (VECM)

\section{Introduction}

The Bank of Tanzania is mandated to formulate and implement monetary policy with the objective of maintaining price stability, while taking economic growth into account. In fulfilling this mandate, among the measures that are undertaken 
by the Bank is to ensure the supply and distribution of currency (notes and coins) to the economy. From the central banks perspective, currency derives its importance from being the narrowest monetary aggregate, with the central bank exercising full control over its supply. In this context, the Bank of Tanzania has a combined obligation and leverage for ensuring that the aggregate supply as well as denominational structure of the currency closely corresponds to what is demanded by the residents. These functions are statutory in nature and are well enshrined in the existing laws. The Bank of Tanzania Act (2006), Section 26 stipulates the following:

"The Bank shall have a sole right to issue bank notes and coins which shall be the only legal tender for Tanzania" In addition, section 27 of the Act require that:

"Bank notes and coins shall be: 1) in such denominations of the shillings and fractions thereof expressed in cents; and 2) of such materials, forms and designs, shall bear such inscription, devices and have such other characteristics as the Bank shall with the approval of the Minister, determine."

The need for the Bank to pay close attention to the factors that influence currency demand is highly indispensable in order to effectively fulfill this mandate. In other words, estimation of evolving demand for currency in the economy and understanding its relationship with various factors is an essential element in maintaining the Bank' wherewithal in terms of planning, issuance and distribution of currency to the economy.

At the same time, with a view to maintaining financial stability, the Bank of Tanzania is vested with the duty of facilitating and securing the payment systems. The Bank of Tanzania Act (2006) Section 6(1) stipulate that:

"The Bank shall:

1) regulate, monitor and supervise the payment, clearing and settlement including all products and services thereof; and

2) conduct oversight functions on payment, settlement and settlement systems, in any bank, financial institution, or any infrastructure service provider or company."

Section 6(2) further requires that, the Bank shall:

1) participate in any such payment, clearing and settlement systems;

2) establish and operate any system of payment, clearing or settlement purposes; and

3) perform the functions assigned by or under any other written law for the regulation of payment, clearing and settlement system.

By fulfilling these tasks, the Bank of Tanzania provides the basis for the public to choose their preferred payment method in any given situation. In the course of implementation of these statutory measures, Tanzania has witnessed a spectacular rise in the use of mobile transactions over the recent years. This sterling development has been exacerbated by rapid technological progress, especially in the area of information technology. Given the current speed of global technological trends, more non-cash payment instruments such as payment apps, credit 
cards, debit cards are expected to be part of country's payment instruments-of course as the resilience and efficiency of domestic financial institutions and markets gains pace.

This evolving environment is of key interest to practitioners as it changes the incentives and structures underpinning the conduct of monetary policy and its effectiveness. Besides, proliferation of payment systems plays a crucial role on monetary policy operations as these require policy instruments through which liquidity can be efficiently injected to or withdrawn from the markets. This means a clear understanding of the implications of payment systems on monetary policy conduct and its effectiveness is essential in order to maintain price stability.

At the same time, there is a growing recognition that significant risks are inherent in payment systems and these need to be understood and managed in a way that are mitigated whilst at the same time, enhancing efficiency of the payment mechanisms and financial stability. In this era of rapid advancement in payment technologies, safeguarding the integrity of the payment system is a goal that acquires particular significance and which calls for enhancing risk management frameworks through the concerted efforts by market participants and the relevant authorities, notable the central bank. Since the payment systems are the critical component of the nation's financial system, the smooth functioning of these systems is vital for the financial stability of the country's economy.

Against this background, the study on mobile payment and demand for cash in Tanzania is intended to achieve four main objectives.

One, is the assessment of recent developments in mobile transactions, the extent these instruments have been adopted by the general public including the underlying conditions that motivate their usage. The second objective is to achieve a better understanding on how developments in mobile transactions in Tanzania has affected the demand for cash holdings including its components (denominations). The third objective is to identify potential challenges associated with increasingly use of mobile transactions, and the implications of these challenges to the effectiveness of monetary policy. The fourth objective is to make recommendations on appropriate policy measures with a view to strengthening monetary policy effectiveness and financial stability in the face of increasingly use of mobile transactions.

Toward this end, the analysis is anchored on the following research inquiries:

- Awareness of payment systems

- To what extent the Tanzanians residents are aware of the existing payment systems?

- Use of payments methods and motives

- What types of methods used by the Tanzanian residents in making transactions and what are the factors influencing that choice?

- Demand for holding cash

- What are the main motives for holding cash and its components (various 
denominations of bank notes)?

- Mobile payments and demand for cash

- Is there any relationship between the demand for cash and mobile phone transactions in Tanzania?

In terms of methodology, this is a desk-based analytical study involving significant work on literature review. The analysis will employ secondary data and other information from various sources to estimate a model of demand for money focusing on its narrow aggregates (currency and its components) that takes into account recent developments in the payments system, with particular attention on mobile transactions.

The desk work is supplemented by field surveys. The strategy in this rather direct approach is to use structured questionnaires, focusing on representative sample, constituting key players in this sub-sector including mobile money service providers and mobile money customers. The survey comprises a personal interview on payment habits and attitudes towards payment instruments. The survey therefore is intended to provide information on the general payments behavior of Tanzanian population and underlying motives for this behavior. It is also aimed to get a better understanding of the use of cash by Tanzanian population.

The rest of the paper is organized as follows. Section two set out a stylized analysis of recent developments on mobile payments and currency in circulation in Tanzania. Section three reviews the literature on the demand for money. It essentially covers both theoretical and empirical literature whilst maintaining a particular focus on those analytical works with features closely reflecting Tanzania's economic environment. The analytical framework including empirical work and survey on mobile phone transactions is undertaken in section four. Section five is dedicated to the summary of findings. Section six provides conclusion and policy recommendations.

\section{Recent Developments}

\subsection{Mobile Phone Transactions in Tanzania}

Over the recent years, Tanzania has witnessed unprecedented increase in mobile phone transactions. Comparing with 2013, the value of mobile payments rose by 53.7 percent reaching TZS 35.3 trillion in 2014, and then by 86.7 percent in 2015 which recorded a value of TZS 42.9 trillion. The trend continued to accelerate with 2016 registering a value of TZS 53.7 trillion or a rise of 133.6 percent. It further rose by 167.5 percent reaching TZS 61.1 trillion in 2017. In 2019 mobile payments reached TZS 88.1 trillion or an increase of 283.2 percent (Figure 1).

Likewise, the volume of transactions related to mobile payment increased significantly during the same period (Figure 2). In particular, the volume of transactions maintained an upward trend, and rose from about 0.8 trillion in 2013 to 2.8 trillion in 2019. Such a sterling development has been gravitated by proliferation of mobile phones, introduction of mobile payment platforms and related financial instruments as well as notable milestones in financial inclusion. 


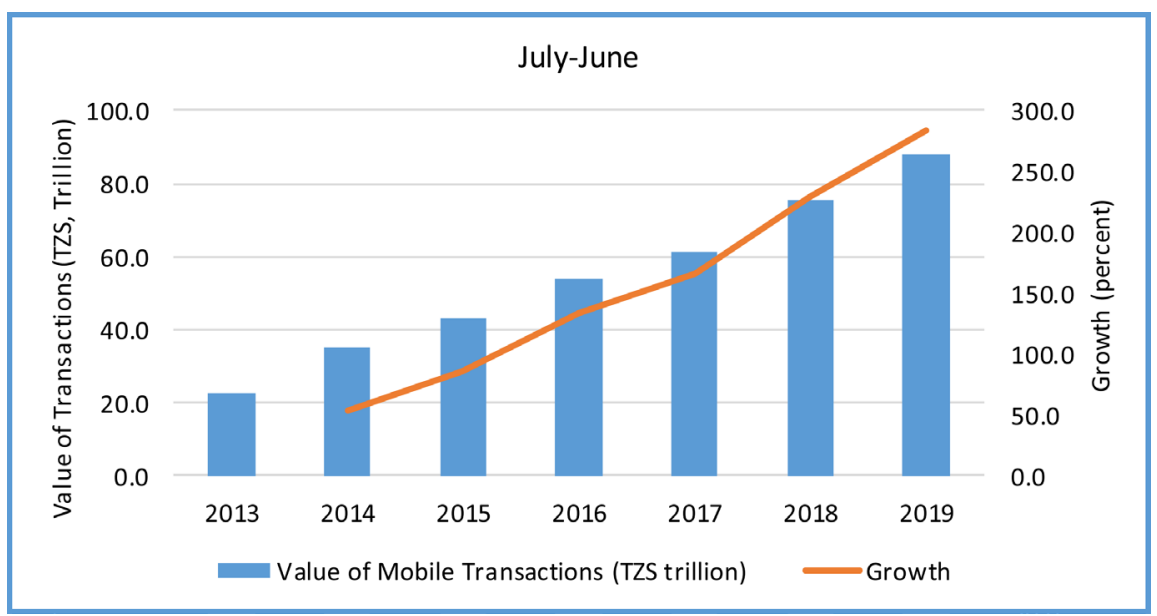

Figure 1. Value of mobile transactions (TZS trillion) and growth (Percent). Source: Bank of Tanzania.

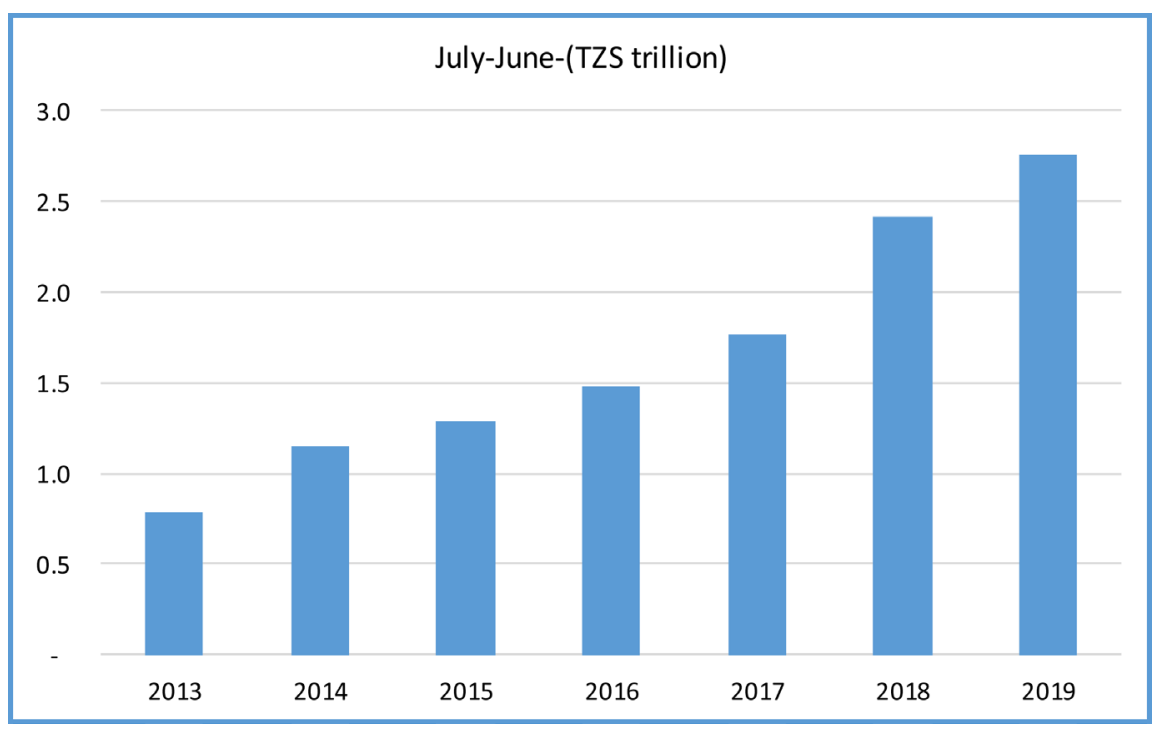

Figure 2. Volume of mobile transactions. Source: Bank of Tanzania.

\subsection{Currency Demand in Tanzania}

The Bank of Tanzania only issues currency to commercial banks (deposit taking institutions) partly basing on the demand by these institutions and partly based on monetary and financial policy considerations. These notes and coins maybe divided into two components namely; currency in circulation and vaults cash. Currency in circulation is the amount of cash that is being held by the public for various reasons including conducting transactions of goods and services. Vault cash on the other hand, are the notes and coins in the vaults of deposit taking institutions. Currency in circulation is frequently used as a proxy for cash demand ${ }^{1}$.

As the central bank is the sole issuer of cash (notes and coins), and since its

${ }^{1}$ Amromin \& Chakravorti (2009). 
objective is to ensure that the demand for cash at any particular time is satisfied, it is of the central bank concern to ensure that the supply of notes and coins is done in most efficient way. For this reason, investigation on what determines demand for cash is critically importance in order for the Bank to plan the production and distribution of currency proficiently.

\section{Trends in Currency Demand}

The increasing pace of mobile payments has led to the belief that demand for cash is supposed to fall following a significant shift from using cash for payment of goods and service. To the contrary, casual observation has shown that the demand for cash holding and the use of mobile money for settling payments have been rising in tandem (Figure 3). For instance, comparing with 2013, currency in circulation outside the banking system rose by 18.7 percent reaching TZS 3.6 trillion in 2014 and then by 35.2 percent reaching TZS 4.1 trillion in 2015. In 2016 the stock of currency in circulation outside banks was TZS 4.3 trillion an increase of 44.3 percent whilst in 2018 it reached TZS 4.5 trillion being an increase of 49.9 percent. In 2019 it rose by 59.9 percent reaching TZS 4.8 trillion.

Likewise, currency in circulation scaled by GDP-which is an indicator of individuals' preference for holding currency relative to GDP rose steadily up 15.8 percent in the quarter ending June 2019 from 11.6 percent in the quarter ending March 2010 (Figure 4). Trend ratio of currency to GDP was more remarkable from 2012 onwards, a period also characterized by the introduction and increasingly use mobile phone transactions. Steady rise in both demand for currency and mobile phone transactions contrast sharply with general belief, as one would expect that the use of cash would have been reduced following a dramatic and increasingly use of mobile phone for conducting transactions. To make a plausible explanation for this development would require, a priori understanding of the factors underpinning the demand for cash.

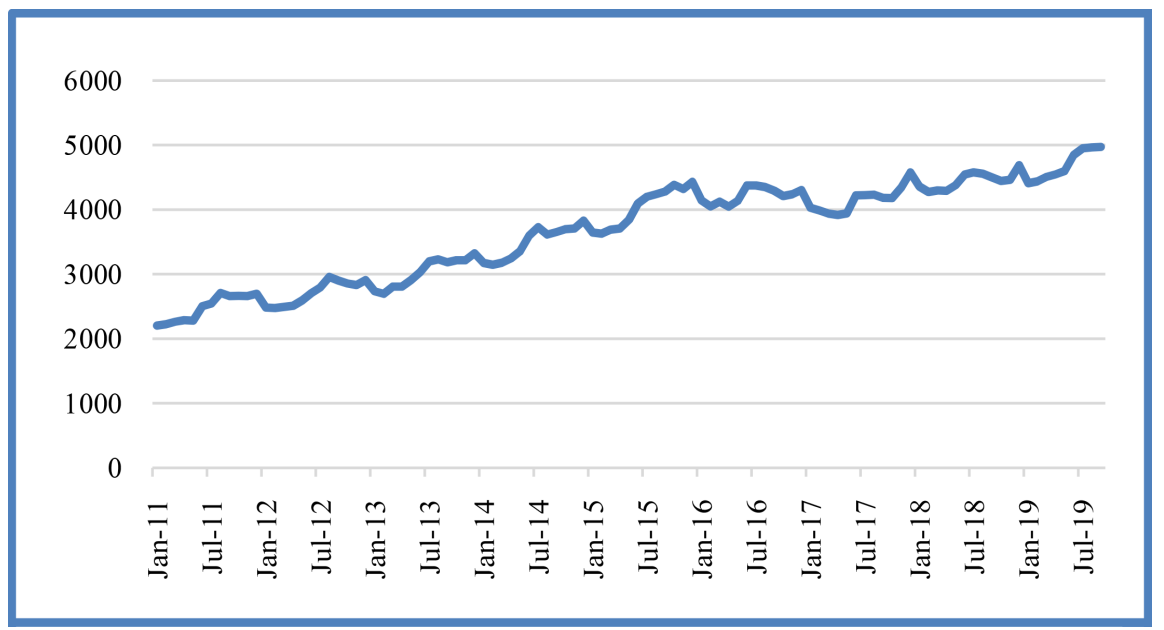

Figure 3. Currency in circulation outside banks (TZS Billion). Source: Bank of Tanzania. 


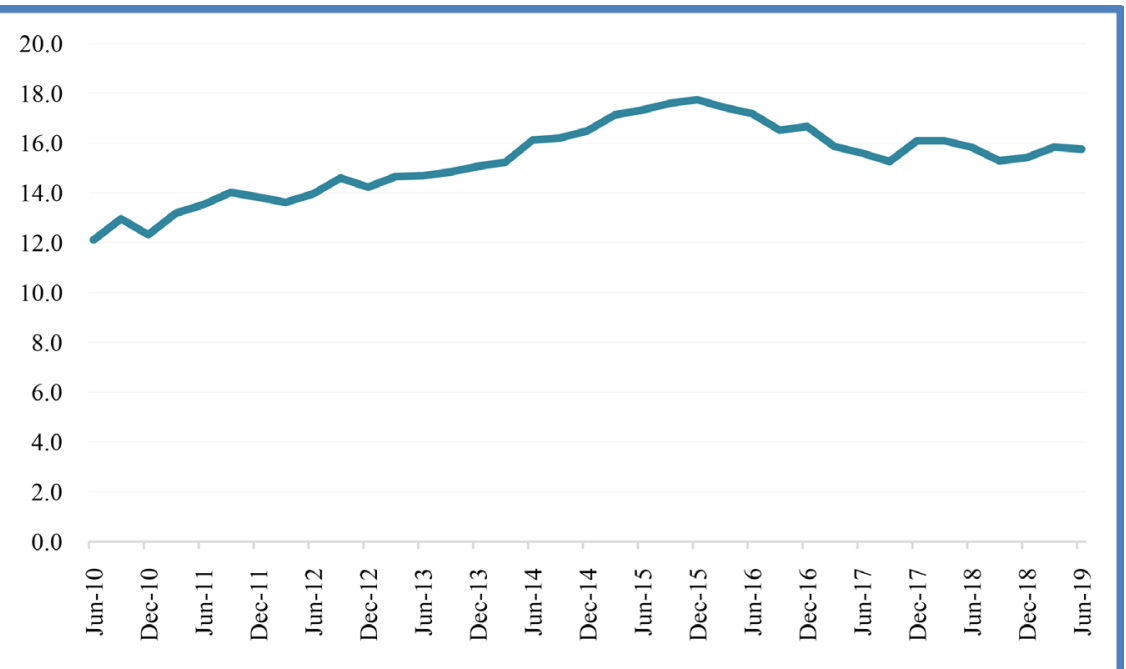

Figure 4. Currency in circulation to GDP (\%).Source: Bank of Tanzania.

Currency in circulation (cash) like other forms of money is used both as a means of payment and a store of value. Following Amromin and Chakravorti (op. cit.) a common way to distinguish the two types of cash demand is to assume that larger denomination banknotes are mostly held as a store of value and smaller ones for payments of goods and services ${ }^{2}$.

The banknotes issued by the Bank of Tanzania and are currently in circulation are shillings 10,000 notes, 2000 notes, 5000 notes and 10,000 notes. While total currency in circulation increased steadily during 2010 to 2018, nevertheless, various components of cash demand measures by trend share of various denomination banknotes to total currency in circulation behaved differently (Figure 5). In Figure 5(a) through Figure 5(c) trend share of 1000 banknotes, 2000 banknotes and 5000 banknotes declined steadily albeit in varying degrees. In contrast, the component of large denomination measures by trend share of 10,000 banknotes to total currency in circulation increased steadily during the sample period (Figure 5(d)).

\section{Literature Review}

\subsection{Theoretical Literature}

Theoretical literature on the demand for money is voluminous, and for this reason we briefly review the most relevant and most closely related to our study. Traditional models of demand for money have evolved on two essential functions of money; the medium of exchange and store of value functions ${ }^{3}$. The medium of exchange function underpins the inventory models Baumol (1952) and Tobin (1956), Cuthbertson, Barlow, \& Taylor (1991). The store of value function has led to asset or portfolio models whereby money is held as part of the portfolio assets of the individuals (Tobin, 1958).

${ }^{2}$ Of course what constitute large note is subjective to the holder.

${ }^{3}$ Duca \& VanHoose (2004) reviews this literature. 


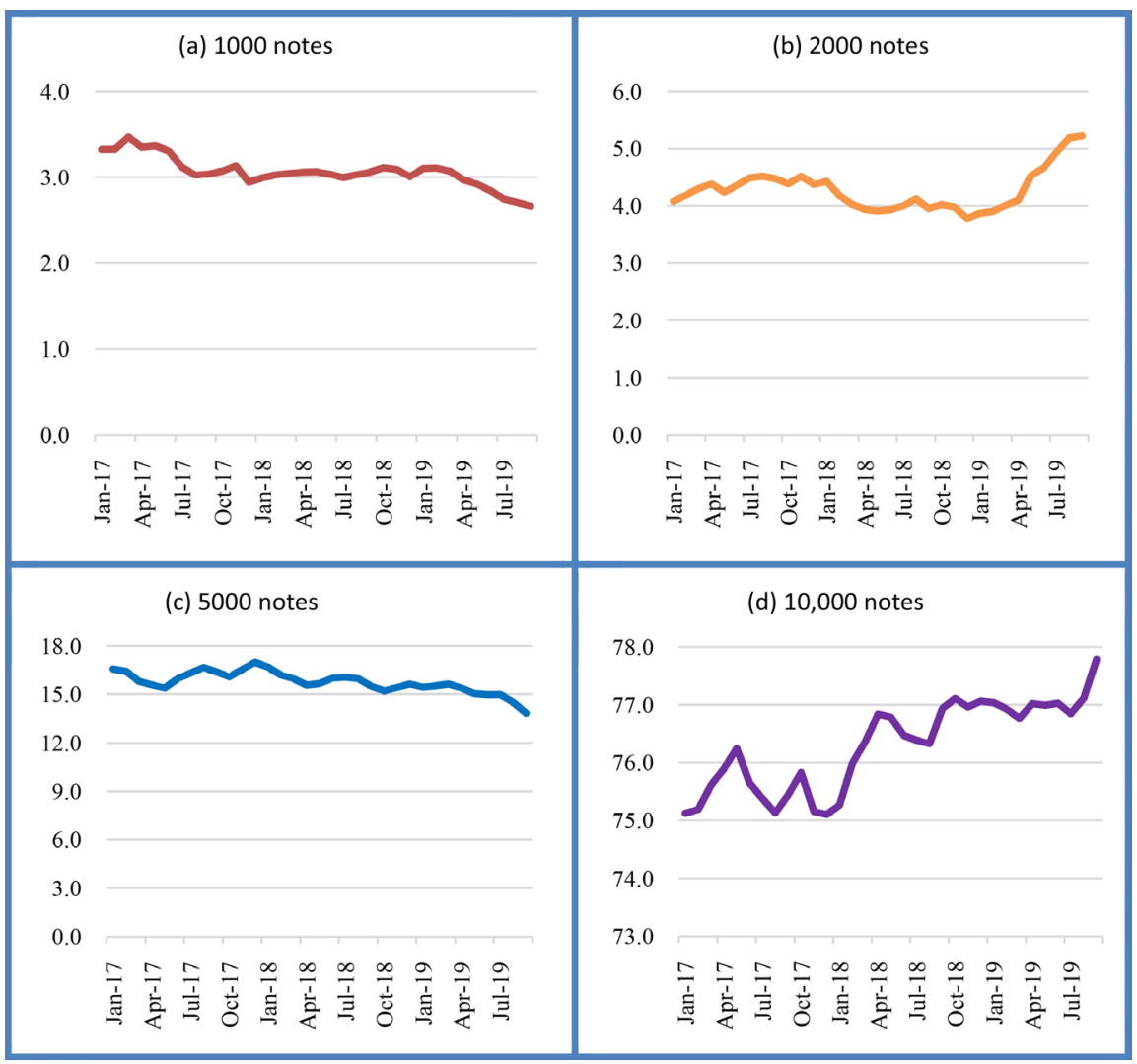

Figure 5. Trend share of notes to currency in circulation (in percentage). Source: Bank of Tanzania.

Baumol (1952) and Tobin (1956) used inventory approach to develop in a deterministic setting, a theory of demand for money in which money was essentially viewed as inventory held for transaction purposes. These authors argue that a cost minimizing consumer will choose his cash holdings so that the marginal cost for larger holdings will, as a consequence of interest forgone on savings, equal to marginal earnings, because fewer visits to the bank are needed to convert savings into money. These models predict that although financial assets other than money may offer higher yields, the transaction costs of going between money and these assets justifies holding cash as inventory for transaction purposes. Cuthbertson et al. (1991) introduces uncertainty by relaxing the assumption that payments and receipts are known with certainty as in Baumol (1952) and Tobin (1956). They show that, the more money an individual hold, the less likely he or she is to incur the costs of illiquidity, but the more interest is being given-up. The key implications in these models is that one optimizes the amount of precautionary cash holding by carefully weighing the interest costs against the advantages of not being caught illiquid.

Another class of models that emphasize transaction role of money is cash in advance models (Lucas, 1980). These are equilibrium models which incorporate some restrictions that purchases in a given period should be paid for by cash brought from the previous period, a limitation known as "cash in advance con- 
straints". These models provide an alternative for including money in the utility function and offers an intuitively appealing and simple analytical tool to investigate why rational agents may hold money.

Theories based on money as store of value are in a class of asset or portfolio models and view the demand for money in the context of portfolio choice (Judd \& Scadding, 1982; Sargent \& Wallace, 1982; Tobin, 1958). In these models, the demand for money is interpreted more broadly, as part of problem of allocating wealth among portfolio assets that include money with each asset generating some income and service flows. In the case of money, the yield includes services such as the ease of making transactions, and in the case of other assets the yield is expected return on these assets. These models consider interest rates and income or wealth to be the principle factors underlying the demand for money.

Traditional models on demand for money are motivated by different hypotheses focusing on transaction, precautionary, speculative and utility, considerations (Judd \& Scadding, 1982). Whilst these models explore the demand for money using different styles and hypotheses, the ensuing implications have been analogous. All have generally shown that, the optimal stock of real money holding is inversely related to the rate of return on earning assets and positively related to the real income ${ }^{4}$.

The striking feature in the traditional theoretical models, is a strong assumption that all payments are made with cash. Recent literature on the demand for money has relaxed this assumption and extended the traditional models by invoking alternative payment methods arising from technological advancement (Attanasio, Guiso, \& Jappelli, 2002; Lippi \& Secchi, 2009; Santomero \& Seater, 1996; Whitesell, 1992).

Lippi \& Secchi (2009) modifies the standard inventory theory by introducing a role of bank branches and ATM terminals in agents' cash holding choices. The key difference with respect to the classic Boumal-Tobin model (Baumol, 1952; Tobin, 1956) where all withdrawals are assumed to be costly is that in the study by Francesco and Alessandro (2008), payment technology is introduced such that agents are given the opportunity to withdraw at no costs. It is shown that in this economy, the level of the demand for money and its interest rate elasticity decreases as the frequency of free withdrawal opportunities increases.

A study by Attanasio et al. (2002) also extend the traditional model of demand for money to take into account innovations in transaction technologies. In the traditional Baumol-Tobin approach, individuals face a trade-off between holding liquidity in the form of money to carry out transactions and forgone interest paid on deposit assets. In the extended version of the model in Attanasio et al. (2002), consumers choose optimal money holdings to trade off time costs of transactions and against the cost of holding cash. Time costs of transactions originate from the shadow value of time and from the "shoe leather" cost of with-

${ }^{4}$ Econometric models for estimating demand for money has always retain this assertion as a starting point. 
drawing cash. Consumers therefore demand optimal money holding by minimizing the cost of transaction time and foregone interest paid on deposited assets subject to their consumption expenditures. Improvement in transaction technology such as contactless payment and lower transaction costs therefore lessen demand for cash. Contactless payment also enables to instantly access liquidity in the accounts for making payments and further reduces demand for cash and maximizes the return on interest paid on deposited assets.

Santomero \& Seater (1996) explore the effect of variations in the number and types of payments in the consumer transaction demand, using a Baumol-Tobin type model of demand for money. The study investigate the behavior of representative consumer faced with a choice of instruments with which to transact and ask how variations in the characteristics of these instruments will affect the consumer choice of transaction vehicle, transaction frequency, and average balance in various transaction instruments. The study finds that variations in the cost of transfer, interest rate, and acceptability of alternative payment instruments determine consumer's choice on the use of payment instrument. In general, the cost of using particular means of payment determines whether it will be used and for which goods it will be traded. One of the key implications of the findings is that the choice of a means of payment has the direct effect on both the average of demand for holding cash and their transaction frequencies

\subsection{Empirical Literature}

Empirical literature on demand for money in form of cash is extensive. In general results from these studies corroborate theoretical predictions that relate demand for cash holdings and its determinants.

Focusing on Turkey and using a Generalized Method of Moments (GMM) method, Yilmazkuday \& Yazgan (2009) analyze the effects of credit and debit cards on currency in circulation by estimating nominal currency holdings as a function of wealth, the price level, interest rates as well as credit and debit card usage. The study finds that both credit and debit cards, lessens currency holdings. They also find, the usage of the debit cards to have larger impact on currency demand than credit card usage. He attributed this to the fact that debit cards were inevitably used to withdraw cash from ATMs whilst credit cards affect currency holding through purchases.

Amromin \& Chakravorti (2009) analyze changes in cash demand for 13 advanced economies from 1988 to 2003 using error correction econometric technique. The estimation strategy separate cash in three denomination categories to disentangle its store of wealth and payment functions. Defining denominations commonly dispensed by automated teller machines (TAMs) as the medium category, they show that demand for small denomination currency decreases with greater debit card usage and with greater retail market consolidation. In contrast, the demand for higher denomination currency decreases when interest rates rise but is generally unaffected by changes in debit card usage. 
Rinaldi (2001) estimate a currency demand equation for Belgium to determine the extent currency had been substituted by alternative means of payments using co-integration technique. The study focuses on the demand for currency equation as a function of GDP, interest rate and measures of financial innovations including the number of debit and credit cards, the number of electronic transfer points of sales (EFTPOS) merchants as well as the number of ATM machines. The results show that in the long-run POS merchants and the number of ATMs have negative impact on currency in circulation. Nonetheless, credit and debit cards usage indicate weak impact on currency holdings.

A study by Snellman, Vesala, \& Humphrey (2001) aims to divulge extent of cash substitution by other payment instruments in 10 European countries. Employing a panel econometric technique, the study estimates demand for currency as a function of GDP, interest rate, debit and credit cards, number of electronic transfer points of sales (EFTPOS) and number of ATMs. Findings of the study indicate cash substitution by these alternative means of payments to be significant with the credit and debit cards playing a larger role than EFTPOS and ATMs. The findings also indicate that the countries themselves are at different stages of this substitution process.

A study by Tanzi (1982) undertakes estimation of demand for cash in the United States and including among the determinants, ratio of taxes to GDP as a proxy of underground economy. The result shows that increase in taxes to GDP ratio raises the demand for currency. The study conclude high taxes induce citizens to evade taxes by shifting part of their economic activities to black or grey economy. This result has been confirmed by Rogoff (1998) and Sprenkle (1993).

Goodhart \& Ashworth (2014) conducts an empirical study to investigate the impact of underground economy on demand for currency in the United Kingdom. The model include currency to GDP ratio as a dependent variable. The independent variables include nominal GDP and interest rate, minor housing repairs and value of added tax. The last two variables (housing repairs and VAT) were used to proxy for the underground economy. The result shows that the underground economy has significant impact in the rise of currency to GDP ratio.

Findings in the literature that the underground economy has significant effect on the demand for currency implies that proper approximations of these activities is important in order to have consistent demand for currency parameters. Because these issues are closely related to our study, we will briefly describe alternative approaches that have been employed in the literature to estimate the underground economy and identify the framework that this paper will adopt. In general, two broad approaches for estimating the underground economic activities exists: direct and indirect methods. Direct approach focuses on the voluntary survey to estimate the underground using survey data (Schneider \& Bajada, 2005). In this framework, individuals in the economy are interviewed to find out their involvement in the underground economy. The approach typically deals 
with soliciting information about respondent's role in the underground economy.

The indirect approach includes national income accounting approach (Lyssiotou, Pashardes, \& Stengos, 2004), the transaction approach (Bhattacharyya, 1999), and multiple indicator multiple cause (Giles, 1999) and monetary approach (Schneider \& Bajada, 2005).

In national income accounting approach (Lyssiotou et al., 2004), the size of the underground economic activities is assumed to be the residual and the analysis focuses on the difference between the legitimate income and expenditure. The transaction approach is based on the quantity theory of money and focuses on overall volume of monetary transaction in the economy to calculate total nominal (unofficial and official) GDP and then estimate the size of underground economy by subtracting official GDP from total GDP (Bhattacharyya, 1999; Boeschoten, 1992). Important assumption underlying this approach is the behavior of velocity of money.

Models based on "multiple indicator multiple cause" (MIMIC) specify the underground economy as latent or index which has causes and effects that are observed but which cannot itself be measured directly. Some causal variables represented in MIMIC models have included the burden of direct and indirect taxes, and the burden of regulation which may trigger agents to operate in the underground economy. For indicator variables, the researchers have included monetary indicators and labor market indicators (Giles, 1999). Values of index are then inferred from data on causes and indicators by estimating a statistical model and predicting the index.

Models that employ monetary approach to estimate the size of the underground economy attempts to identify the extra currency that may be attributed to the factors which may explain the size of underground economy. The approach uses econometric tools to estimate currency demand model with determinants (independent variables) stemming from both official (recorded) economy and the underground economy. Once the amount of currency related to the underground economy is estimated, it could be multiplied by income velocity of money to get a measure of the size of the underground economy (Schneider \& Bajada, 2005).

\subsection{Literature on Surveys on Individuals' Payments Habits}

In addition to aggregate based studies to assess the impact of noncash payments on demand for cash, some authors have based their analyses on direct approach by conducting surveys to individuals and their payment habits. Thus individuals in the economy are interviewed to find out their involvement in the payments methods and holding of currency. The questions typically deal with soliciting information about respondent's role in payment system either as a buyer or as a service provider.

Stix (2004) study involved surveys conducted to individuals and their pay- 
ment habits in Australia. He finds that those individuals that make purchases frequently with debit cards on average hold 20 percent less cash in their wallets and those that frequent ATMs hold 18 percent less cash in their wallets. For France, Bounie \& François (2006) find that transaction size, type of good and where the purchase is made are key factors for the consumer choice of a payment instrument. They also find that cash and cheques are common when merchants do not accept payment cards. In addition, they are able to confirm well-established demographic factors that determine payment usage such as age, education, and gender.

\section{Analytical Framework}

\subsection{Specification of the Empirical Model}

While most studies on the demand for money in Tanzania have focused on the use of broad monetary aggregates, in this study we concentrate on the narrowest measure, that is currency in circulation. The empirical model we employ in our study is in spirit with the traditional theory of demand for money as developed by Baumol (1952) and Tobin (1956), and extended by Attanasio et al. (2002) who take into account innovations in transaction technologies. As in Drehmann \& Goodhart (2000) our specification also take into account the underground economy or economic activities that escape detection in the official estimates of gross domestic product but still have bearing on the demand for cash. Following (Adam et al., 2011; Bhattacharyya, 1999) we proxy for the underground economy by deriving the value of economy's transactions through the equation of exchange and compare with the official GDP. In this context, we postulate in Equation (1) the demand for currency $\left(c_{t}\right)$, as a function of nominal official GDP $\left(\operatorname{GDP}_{t}^{\text {off }}\right)$, interest rate $\left(i_{t}\right)$, the exchange rate $\left(e_{t}\right)$, inflation $\left(\mathrm{CPI}_{t}\right)$, value of mobile transactions and underground (unofficial) GDP ( $\left.\operatorname{GDP}_{t}^{\text {unoff }}\right)$. The error term $\left(\zeta_{t}\right)$ is assumed to be independent and identically distributed (iid).

$$
\begin{aligned}
\ln \left(c_{t}\right)= & \beta_{0}+\beta_{1} \ln \left(\mathrm{GDP}_{t}^{\text {off }}\right)+\beta_{2} i_{t}+\beta_{3} \ln \left(e_{t}\right)+\beta_{4} \ln \left(\mathrm{MOB}_{t}\right) \\
& +\beta_{5} \ln \left(\mathrm{CPI}_{t}\right)+\beta_{6} \ln \left(\mathrm{GDP}_{t}^{\text {unoff }}\right)+\zeta_{t}
\end{aligned}
$$

As in Drehmann, Goodhart, \& Krueger (2002) and Amromin \& Chakravorti (2009) we also use different measures of dependent variable that include total currency in circulation, demand for notes of small denomination and demand for notes of large denomination. The aim here is to shed some light on the compositional effects within the currency stock on the underlying motives for holding various denominations of bank notes.

A priori, we expect demand for cash to fall with a rise in interest rate and accordingly a negative association between currency and interest rate. At the same time, basing on transaction motive the demand for cash will have positive relationship with both recorded income (GDP) and unrecorded income (underground GDP). In theory, improvement in alternative payment methods lessens the need for using cash to conduct payment of goods and services. For this rea- 
son, the relationship between currency in circulation and mobile transactions is expected to be negative. The transaction demand for currency increases as price level rises hence we expect the coefficient of CPI to be positive. The inclusion of exchange rate captures the portfolio choice that asset holder face. Movement of exchange rate constitute an important element of relative rate of return on alternative asset facilitated in the foreign exchange market. This implies that the exchange rate parameter is expected to have a negative sign.

\subsubsection{Estimation}

To investigate the impact of alternative means of payment on currency demand, the study employs the use of a Cointegration and Error Correction Modeling (ECM) framework to specify an appropriate long-run currency demand function for Tanzania (Johansen, 1988; Johansen \& Juselius, 1990). The long-run relationship in the model of currency demand (Equation (1)) can be transformed in the following error correction representation ${ }^{5}$ :

$$
\Delta Z_{t}=\Phi+\sum_{i=1}^{n} \Theta \Delta Z_{t-1}+\Pi Z_{t-1}+\zeta_{t}
$$

where $Z_{t}^{\prime}=\left(C, \mathrm{GDP}_{t}^{\text {off }}, i_{t}, e_{t}, \mathrm{CPI}_{t}, \mathrm{MOB}_{t}, \mathrm{GDP}_{t}^{\text {unoff }}\right), \Phi$, is a vector of intercept, $\Theta$ is matrix of coefficients for short-run responses; and

$$
\Pi=\alpha \beta^{\prime}=\left(\begin{array}{ccc}
\alpha_{11} & \cdots & \alpha_{16} \\
\vdots & \ddots & \vdots \\
\alpha_{61} & \cdots & \alpha_{66}
\end{array}\right)\left(\begin{array}{ccc}
\beta_{11} & \cdots & \beta_{16} \\
\vdots & \ddots & \vdots \\
\beta_{61} & \cdots & \beta_{66}
\end{array}\right)
$$

The elements of matrix $\alpha$ are known as loading coefficients and ensure the speed of adjustments, while the vector $\beta$ characterizes the long-run elasticities.

\subsubsection{Data Issues and Diagnostic Analysis}

Data used in the estimation of ECM includes currency in circulation, nominal GDP, consumer price index (CPI), 3-month treasury bills rate (proxy for opportunity cost), exchange rate, value of mobile phone transactions and a variable representing an estimate of underground economy. The Treasury bill rate is used as it may be viewed as an alternative asset to holding money given that Treasury bills are very liquid and represent a risk free rate of return ${ }^{6}$. Likewise, the variable for mobile phone transactions is included to the model to assess the impact of this alternative payments to the demand for currency. Variable for the underground economy is derived using the transaction approach focusing on monetary data from the bank of Tanzania and adopting income velocity of money as estimated in Adam et al. (2011). The nominal effective exchange rate calculated as the weighted average of bilateral exchange rates is used to represent the exchange rate variable. We estimate this model using monthly data with sample running from January 2012 to June 2019. All variables except interest rate are in logarithms. The principal source of the data used in the estimation is the Bank of

${ }^{5}$ Cusbert \& Rohling (2013).

${ }^{6}$ See for example Sriram (1999) and Stix (2004). 
Tanzania. Necessary diagnostic tests including, descriptive statistics, unit roots tests and co-integration tests are reported in the Appendix.

\subsubsection{Estimation Results}

Following the above tests, Johansen (1988) multivariate co-integration framework was used to determine the co-integration relations. Johansen and Juselius method is based on the maximum likelihood estimation procedure to calculate two test statistics known as trace and maximum eigenvalue that are used to determine the number of co-integrating vectors.

The parameter estimates are presented in Table 1. With some exceptions, the parameters (long-run and speed of adjustments) for all models (total currency in circulation and for each denominations) turn out as expected in terms of signs and robustness albeit in varying degrees of significance. The signs of the coefficients of mobile transactions are negative confirming that proliferation of mobile phone transaction has been lessening the demand for cash holding. This is exacerbated by the interest rate effect (negative sign of the coefficients of 3-month treasury bills rate). Incidentally, the coefficients of interest rate are significant for total currency in circulation and large denominations (10,000 and 5000 notes) but insignificant for smaller denominations (1000 and 2000 notes).

Table 1. Error correction models: Long-run estimates of demand for currency.

\begin{tabular}{|c|c|c|c|c|c|}
\hline Variable & 1000 Notes & 2000 Notes & 5000 Notes & 10,000 Notes & All cash \\
\hline \multirow{3}{*}{ Speed of adjustment $(\alpha)$} & $-0.109^{\star *}$ & $-0.063^{*}$ & $-0.22^{* *}$ & $-0.20^{*}$ & $-0.24^{* *}$ \\
\hline & -0.051 & -0.034 & -0.064 & -0.102 & -0.113 \\
\hline & {$[-2.122]$} & {$[-1.851]$} & {$[-3.442]$} & {$[-2.033]$} & {$[-2.197]$} \\
\hline \multirow{3}{*}{$\operatorname{GDP}^{\text {off }}(\beta)$} & $4.075^{\star *}$ & $1.679^{\star \star}$ & $0.928^{* *}$ & $6.355^{*}$ & $3.934^{* *}$ \\
\hline & -1.625 & -0.815 & -0.413 & -1.997 & -1.472 \\
\hline & {$[2.507]$} & [ 2.059] & {$[2.244]$} & {$[3.183]$} & {$[2.671]$} \\
\hline \multirow{3}{*}{$\operatorname{GDP}^{\text {unoff }}(\beta)$} & $1.897^{* *}$ & $2.750^{*}$ & 0.121 & $1.772^{\star *}$ & $1.246^{* *}$ \\
\hline & -0.092 & -0.62 & -0.065 & -0.956 & -0.699 \\
\hline & {$[2.126]$} & {$[4.428]$} & [1.869] & [1.853] & {$[1.782]$} \\
\hline \multirow{3}{*}{ T-bills rate $(\beta)$} & & & $-2.081^{\star *}$ & $-6.201^{\star *}$ & $-4.038^{\star *}$ \\
\hline & $\ldots$ & $\ldots$ & -0.949 & -2.614 & -1.972 \\
\hline & & & {$[-2.192]$} & {$[-2.372]$} & {$[-2.048]$} \\
\hline \multirow{3}{*}{$\mathrm{CPI}(\beta)$} & $7.460^{* *}$ & $5.538^{\star *}$ & $0.131^{*}$ & $4.568^{*}$ & $4.377^{\star}$ \\
\hline & -2.072 & -1.705 & -0.037 & -2.107 & -1.578 \\
\hline & {$[3.601]$} & {$[3.248]$} & {$[3.530]$} & {$[2.167]$} & {$[2.773]$} \\
\hline \multirow{3}{*}{ Exchange rate $(\beta)$} & & & & -1.453 & $-0.998^{*}$ \\
\hline & $\ldots$ & $\ldots$ & $\ldots$ & -0.609 & -0.467 \\
\hline & & & & {$[-2.382]$} & {$[-2137]$} \\
\hline \multirow{3}{*}{ Mobile $(\beta)$} & $-1.567^{\star *}$ & $-0.427^{\star *}$ & $-0.074^{\star *}$ & $-1.598^{\star}$ & $-1.126^{* *}$ \\
\hline & -0.269 & -0.225 & -0.022 & -0.27 & -0.204 \\
\hline & {$[-5.832]$} & {$[-1.906]$} & {$[-3.375]$} & {$[-5.909]$} & {$[-5.531]$} \\
\hline
\end{tabular}

Source: Authors' Estimations. ${ }^{*}$ indicates significance at 5 percent level while ${ }^{*}$ indicates significance at 10 percent level. Standard errors in ( ) and t-statistics in [ ]; ...indicate that the variable was not statistically significant. 
Nonetheless, these findings do not support the belief that the overall demand for cash holding should decline overtime as the mobile transactions gain pace. This is due to other factors operating in the opposite direction as accentuated by the coefficients of real income and inflation. Real income (both recorded and unrecorded) appear to be the main driver of the demand for cash holding in Tanzania. However, the impact on demand for cash holding seems to appear larger with the recorded than unrecorded income. The increase in real income (recorded and unrecorded) raises the demand for cash holding in all denominations although at varying degree- a variation that may be attributed to availability of these denominations. In addition to income, all estimated coefficients of CPI appear with positive signs confirming the hypothesis that the transaction demand for currency increases as price level rises in order to command the same amount of goods and services.

Basing on these empirical findings, trend increase in demand for currency holding in the midst of rising mobile transactions implies that the combined effect of factors that lessen demand for currency (interest rate, exchange rate and mobile phone transactions is more than offset by the combined effect of factors driving the demand for currency holding (income (recorded and unrecorded) and inflation).

\subsection{Mobile Payments Survey (MPS)}

This section sets out, on the basis of the interview statements, whether respondents express a fundamental preference for the use of cash or non-cash payment methods, which payment methods they are aware of and possess and how they rate the features of these payment methods. This is of particular importance for the investigation of payment habits and attitudes towards payment instruments, as well as motives for keeping cash at home. The survey team interviewed some 1047 Tanzania residents between November and December 2018. Table 2 summarizes key aspects of the survey design.

Table 2. Key aspects of the survey design.

\begin{tabular}{cc}
\hline & Description \\
\hline Methods & Personal interview through structured questionnaire \\
Survey population & Selected cities: Dar es Salaam and Dodoma \\
Sampling procedures & Random quota \\
Field time & Three weeks \\
Gross sample & 1047 (739 service providers, 308 customers $)$ \\
Adjustable sample & Male 595 , Female 422 \\
Gender & None \\
Incentive & service providers, 308 customers $)$
\end{tabular}




\section{Characteristics of the Respondents}

The survey covered both service providers as well as the customers. The service providers include hospital/health facility/dispensary; clothing and footwear; electronics (computers and musical instruments); building materials; restaurants \& bar; cosmetics and hair dressing saloons; transportation; accommodation; shops; wood works and iron steel activities; supermarket; automobile sales, services and spare parts; stationary and related items; petrol station; and other services. The customers interviewed were of different social economic characteristics in terms of occupation, education, age and gender as indicated in Table 3.

\subsection{Mobile Payments Survey (MPS)}

\subsubsection{Prevalence of Payment Methods}

Regarding the awareness of payment instruments, respondents spontaneously cite an average of three alternatives payment instruments namely; cash, mobile money and bank transfers. On the use of these alternative instruments, about 68.2 percent of the respondents, report that they make payments using cash, 11 percent make payments through mobile phones, 0.3 percent make payment through credit cards and 20.5 percent make payment using bank transfers (Figure 6).

Table 3. Demographic characteristics of customers.

\begin{tabular}{|c|c|}
\hline Occupation & Percent \\
\hline Self-employed & 54 \\
\hline Private sector employees & 23 \\
\hline Government employees & 13 \\
\hline Students and Unemployed & 10 \\
\hline \multicolumn{2}{|l|}{ Education } \\
\hline Primary education & 25 \\
\hline Secondary education & 31 \\
\hline college diploma/certificate & 21 \\
\hline University degree & 23 \\
\hline \multicolumn{2}{|l|}{ Age (in years) } \\
\hline 18 to 30 & 38 \\
\hline 31 to 45 & 48 \\
\hline $46+$ & 14 \\
\hline \multicolumn{2}{|l|}{ Gender } \\
\hline Male & 56 \\
\hline Female & 44 \\
\hline
\end{tabular}

Source: Survey data. 


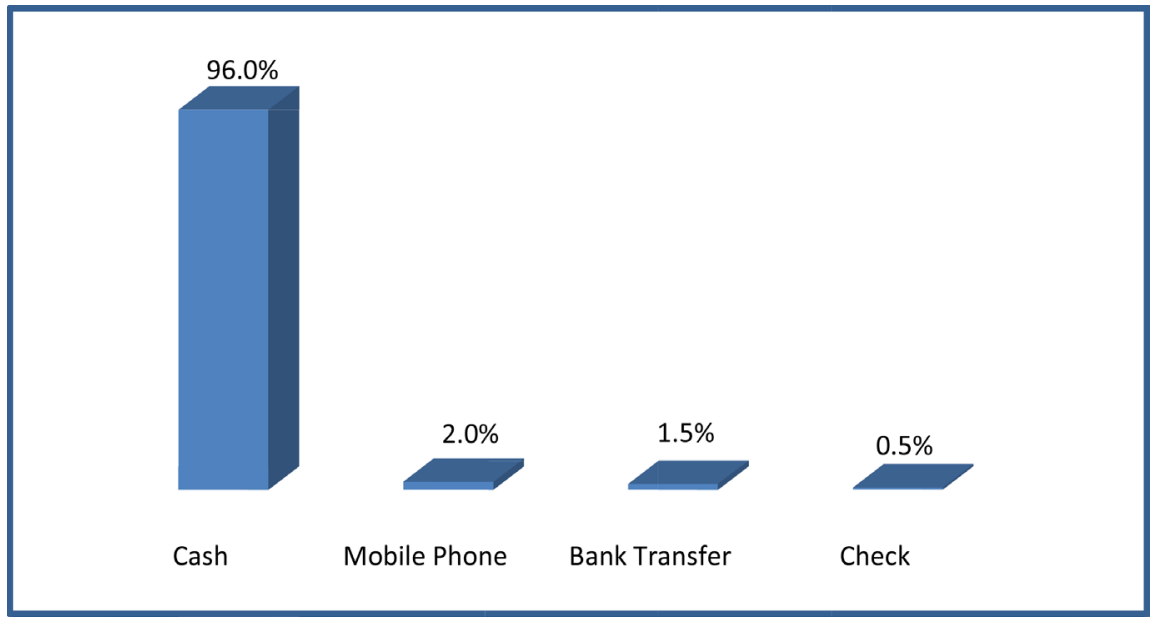

Figure 6. Preferred method of payment. Source: Survey data.

Payment through mobile platforms is more pronounced in particular segments of services such as payment for regular bills like electricity, telephone, water, internet, TV subscription and sending money to family and friends. Otherwise, the use of mobile platforms in making payments for other goods and services is still minimal as shown in (Figure 7).

These findings show that while trend in the use of mobile phones as a method of effecting payments has been rising, nonetheless, its level is still low when compared with the use of cash. One plausible explanation for this difference is that cash as a statutory payment method is accepted virtually everywhere, whereas cashless payment methods cannot be used in every situation. The survey reveals that the low level of mobile payments in relation to the use of cash is also attributed to various factors which include; reluctant by service providers to accept payments through mobile phones for fear of theft and fraud, difficult to get refund when there is transfer failure across networks, risks of sending money to unintended recipient, low and limited amount to be transacted per day, high transaction and operational costs, inadequate agents with sufficient amount of money (float), and poor network in some cases.

When asked to indicate how far bank facilities from their businesses, most of respondents mentioned that the banks, bank agencies and AMTs are not far away (Figure 8). The survey found that ATMs are the most frequently used sources of cash as the 57 percent of the respondents withdraw cash from this source. By far the most-cited reason for withdrawing cash is the purchase of goods and services. Other frequently cited reasons include topping up cash holdings to the desired level.

\subsubsection{Factors that Influence the Choice of Payment Method}

According to the survey, several factors affect the choice of payment methods. They include security, acceptance, user-friendliness, simplicity of payment (acceptance and availability of payment instrument), costs associated with payment, payment amount, place of payment and social demographic characteristics. 


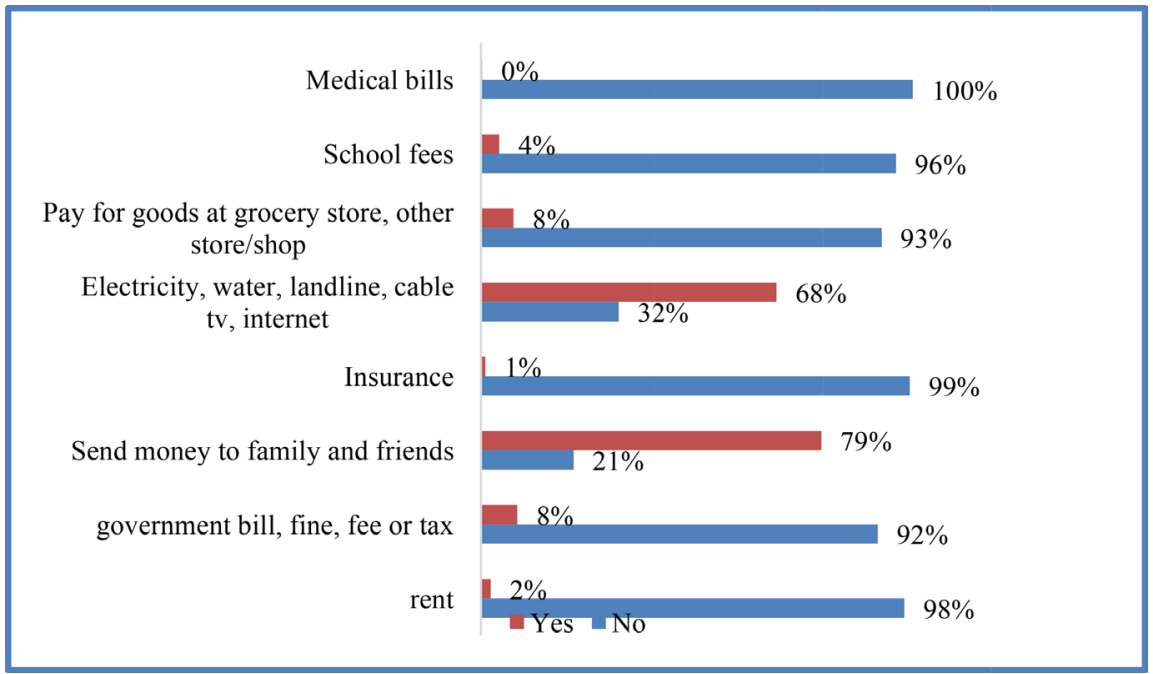

Figure 7. Use of mobile platforms for payment of various goods and services. Source: Survey data.

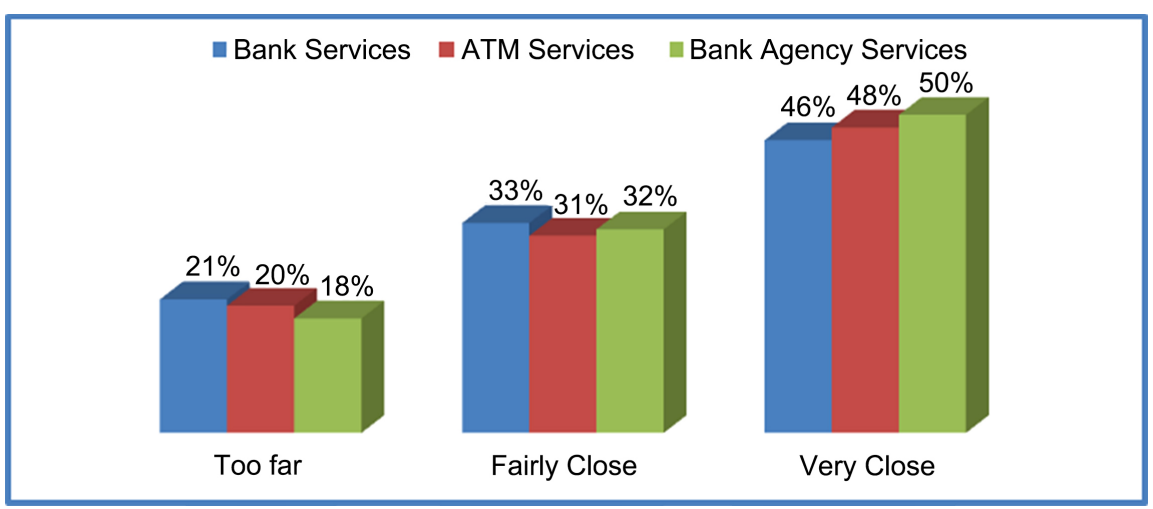

Figure 8. Availability of bank facilities near the business area. Source: Survey results.

Accordingly, respondents were asked to evaluate these features for the most widely used payment methods, namely cash, mobile payments and credit cards. Cash payment fares best on the categories of acceptance, user-friendly, speed of deployment and associated costs. Payment by mobile phone performs unfavorably against cash only in the area of cost, but comes out slightly better on the aspect of security. This may be attributable to the fact that cash can be irrevocably lost or stolen, whereas the equivalent loss through mobile payment is limited.

The use of credit cards featured out worst in all of the five categories surveyed. In most cases the majority of respondents (about 90 percent) did not undertake any evaluation of credit cards. This is presumably explained by the fact that many respondents still do not have much experience with this relatively new payment procedure (Figure 9).

Assessment of survey information shows that there is a considerable difference in payment behavior between different social demographic group. For instance, the age of respondents aged 45 and above undertake their payments using cash compared to the survey average, whereas respondents in the youngest 


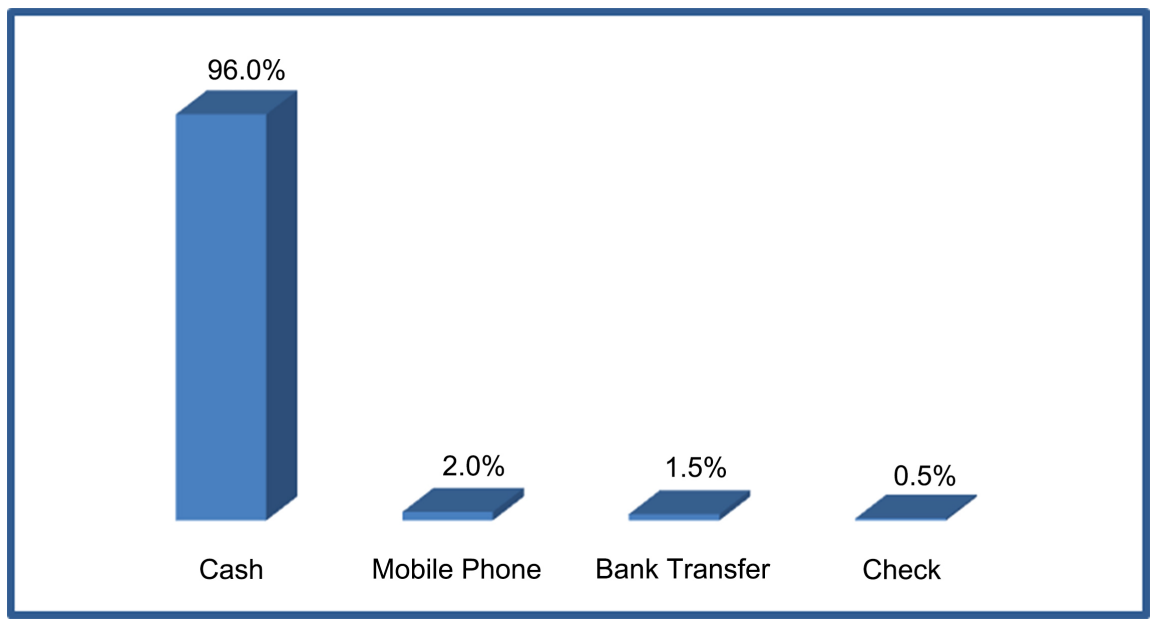

Figure 9. Acceptance of payment method. Source: Survey results.

age group undertake their payment in mobile payments. Viewed overall, however, a significant proportion of transactions are settled with cash across all age groups. Moreover, the youngest age group as a whole processes much smaller payment amounts than the other age groups, which is likely to be primarily explained by their lower incomes. Differences between genders, however, turn out to be relatively insignificant overall.

Assessment of survey information shows that there is a considerable difference in payment behavior between different social demographic group. For instance, the age of respondents aged 46 and above undertake payments using cash and bank transfers only, whereas respondents in the youngest age group undertake payment using cash, mobile payments and bank transfers. Viewed overall, however, a significant proportion of transactions are settled with cash across all age groups (Figure 10). Nevertheless, the assessment of payment methods in terms of gender revealed no significant difference (Figure 11).

\subsubsection{Preferred Method of Keeping Money}

In addition to obtaining information on payment behaviour and the underlying motives, the survey also dwells on understanding of the use of cash by the population. The survey information helps to answer questions of interest such as, what role does cash play for the households, and what motives lie behind its retention? To start with, the respondents were asked to indicate the methods they prefer to keep their money, 37 percent of the respondents indicate that they prefer to keep their money in the form of cash, 49 percent indicate that they prefer to keep their money in banks, and 14 percent indicate that they prefer to keep their money in mobile phones (Figure 12).

The respondents who prefer to keep cash, 78 percent say they keep cash at home in addition to the cash they carry around (in the wallets). When asked to indicate changes in the amount of cash held over time, about 72 percent of the respondents who hold cash state that the amount of cash they currently hold is slightly higher than ten years ago. The main reason given for the increased in 


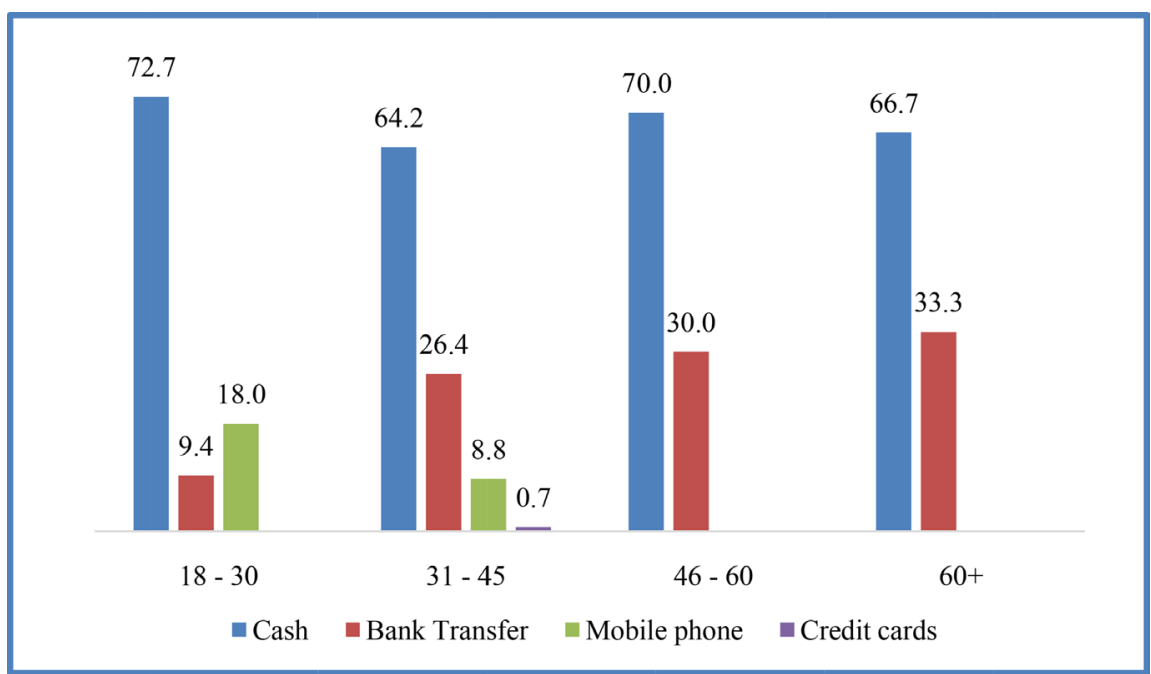

Figure 10. Preferred method of payment by age. Source: Survey results.

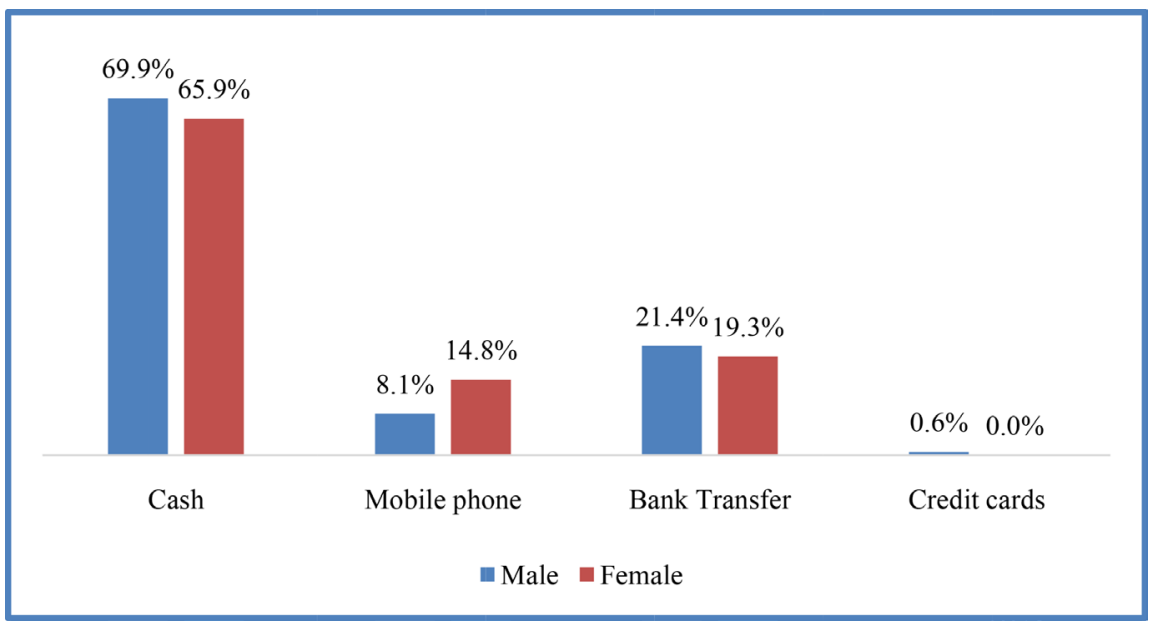

Figure 11. Preferred method of payment by gender (percent). Source: Survey results.

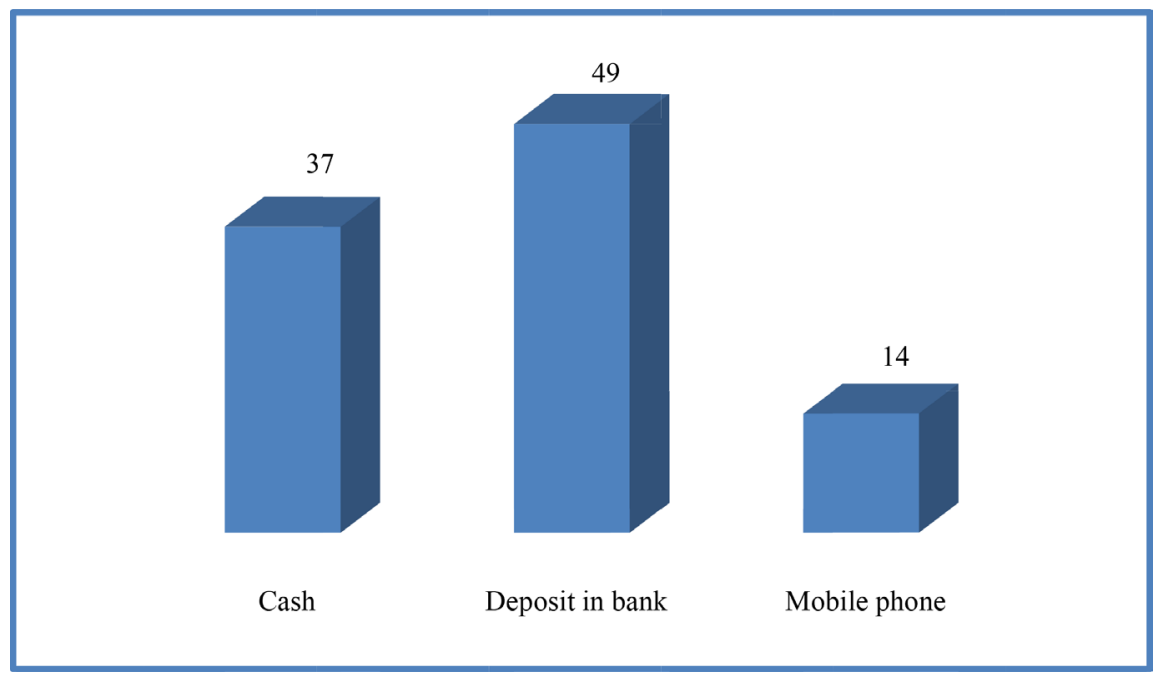

Figure 12. Preferred method of keeping money. Source: Survey results. 
keeping cash is the increase in the amount of cash available compared to the previous reference date, due to either higher income or higher wealth. Nonetheless, a rather smaller amount of respondent (18 percent) hold about the same amount of cash as ten years ago, while 10 percent of the respondents had slightly lower holdings of cash compared to ten years ago.

Regarding the reasons for preference for holding cash, 67 percent of the respondents said they keep cash as part of their wealth (store of value) and 33 percent said that they keep cash in order to meet their day to day transactions (purchase of goods and services).

Among the respondents who hold cash as store of value, 72 percent cite its immediate availability in case of need as the main reason suggesting that the use of cash as a store of value is primarily driven by the desire to be prepared for unforeseen contingencies (precautionary motive for holding cash). Other reason for holding cash as a store of value cited by the respondents is saving. This latter motive is very much related to speculative motive since most of the respondents (68 percent) who hold cash as store of value indicated that low interest rates offered by banks as well as high fees and taxes charged by the banks contributed to desire to hold cash at home. Indeed, one of the striking observations is that 80 percent of those who preferred to keep cash as store of value also maintained bank accounts.

\subsubsection{Assessment of Future Payment Behavior}

Despite these constraints to mobile phone payments, the adoption rate for mobile payments is growing along with technological advancements. Most responded indicated that there has been an increasing trend of payment receivables on goods and services from mobile phone transactions (Figure 13). Thus, there is high expectation of faster growth of mobile payment market.

Although the cash transaction is still dominating in the economy, fast growing mobile money services would be the major driver of improving of financial access in the country, thus could foster financial inclusion. The current limited

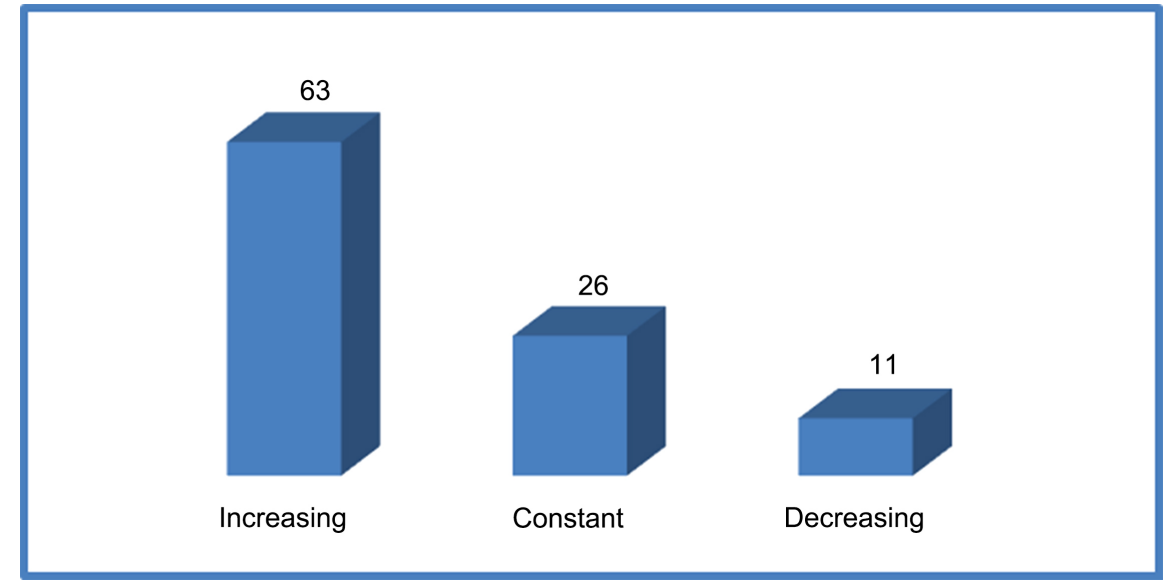

Figure 13. Perception on the future use of mobile phone for making transactions (percent). Source: Survey results. 
cap on daily mobile payments and account balances, together high transaction costs, discourage payments and deter inclusion. There is urgent need to gradually increase this ceiling and foster cross-border mobile money transfers, all of which would reduce cost for low-income households.

\section{Summary of Findings}

\subsection{Empirical Findings}

Empirically, this study has confirmed that long-term determinant of demand for currency holding in Tanzania include, real income (recorded and unrecorded), interest rate (measured as 3-month treasury bills rate), access to payment system (proxied by mobile phone transactions), domestic inflation and exchange rate. Proliferation of mobile phone transactions has lessened the demand for cash holding. This effect is exacerbated by return from holding alternative assets as exemplified by the 3 -month treasury bills.

On the other hand, increase in the demand for cash holding is by and large due to real income vindicating the role of transaction and precautionary motives. The increase in real income (recorded and unrecorded) raises the demand for cash holding in all denominations although at varying degree-a variation that may be attributed to availability of these denominations. In addition to income, domestic inflation contributes positively to the demand for cash; confirming the usual belief that the transaction demand for currency increases as price level rises in order to command the same amount of goods and services.

Basing on these findings, trend increase in demand for currency holding in the midst of rising mobile transactions implies that the combined effect of factors that lessen demand for currency (interest rate, exchange rate and mobile phone transactions is more than offset by the combined effect of factors driving the demand for currency holding (income and inflation).

\subsection{Survey Findings}

Consumer payment survey (CPS) expanded on the empirical work and ask questions related to usage of cash by respondents across social economic characteristics. In addition, the survey aimed to uncover the extent respondents use non-cash payment methods for making transactions with special focus on mobile money. Other issues of interest included factors encouraging usage of mobile platforms and possible challenges limiting their usage.

Overall, the survey indicates that whilst transactions using cash is dominant, usage of mobile platforms for making transactions is widespread among the respondents. Cash is of exceptional importance in view of its statutory features that makes it to be accepted everywhere and other characteristics such as absence of transaction costs. Whilst cash is held for payment of goods and services, a significant amount is also held as a store of value essentially for speculative reasons.

According to the respondents, the increasingly use of mobile platforms for 
making transactions is influenced by a number of factors including availability of service providers, security considerations with respect to large value payments, acceptance of these instruments, costs associated with payment, payment amount and proximity to ATMs/Banks.

The survey reveals some structural impediments limiting the use of mobile transactions. These include, reluctant by service providers to accept payments through mobile phones for fear of theft and fraud, difficult to get refund when there is transfer failure across networks, risks of sending money to unintended recipient, low and limited amount to be transacted per day, high transaction and operational costs, inadequate agents with sufficient amount of money (float), and poor network in some.

\section{Conclusion and Policy Recommendations}

\subsection{Conclusion}

This study has shown that mobile phone transactions have progressively gained pace in Tanzania over the recent years and is now the most used method of payment after cash. The increasingly usage of mobile phones for conducting transactions is being driven by a number of factors including security for not carrying cash, simplicity in terms of speed and outreach among the counterparties and acceptance of this method of payment.

Despite this development, the demand for cash holding (currency in circulation) has remained unabated. This is because the combined effect of factors that reduce demand for cash is more than offset by the combined influence of factors driving the demand for currency holding with GDP playing a leading role. It is thus evident that persistent economic growth over the recent years has strongly supported the transactional and precautionary demand for cash. Consequently, the demand for cash holding for transactional purposes has not fallen despite an increase in payments made through mobile phones.

This paper has limited its scope to analyze the impact of mobile phone money transactions on cash demand and limited data is available on mobile money transactions since these services were launched in 2012/13 in Tanzania. Given the passage of time and technology adoption the results in the future may differ from those obtained in this paper.

\subsection{Policy Recommendations}

\subsubsection{Monetary Policy Strategy}

The increasingly use of mobile instruments for making transactions has two implications. First, it creates additional pressure on income velocity of money which needs to be considered during monetary policy formulation. Second, the increasingly use of mobile instruments means that they provide a role of "monetary component" which has to be considered in the monetary aggregate used in the policy framework. This development call for reviewing the current "divisia monetary aggregate" (which is M3), to include new components arising from opera- 
tions of mobile money ${ }^{7}$. For proper construction of the new divisia, it is essential that data on the amount of mobile outstanding balances are made available and issuers of electronic payments platforms need to provide all relevant statistics.

\subsubsection{Regulatory Framework}

Payment systems are the important part of the financial structure of the country and efficiency in the functioning of these systems is indispensable for engendering financial stability. This means that regulatory bodies, central bank in particular, should put in place regulatory measures to ensure that payment instruments operate efficiently. In the case of mobile money transactions, the following regulatory are recommended.

\section{- Prudential Supervision}

Issuers of electronic money must be subject to prudential supervision. In order to preserve the stability of and to maintain confidence in the financial system, an adequate level of financial soundness, sound risk management, and ongoing supervision need to be maintained.

- Transparency, legal framework, and protection against criminal abuse The issuance must be subject to solid and transparent legal arrangements.

The rights and obligations of the respective participants, including issuers, merchants, and customers, must be clearly defined and be enforceable. The need for well-defined legal structure is especially evident when a scheme operates on a cross-border basis. Adequate technical and organizational safeguards should be maintained to prevent threats to the security of the payment instruments such as counterfeit.

\section{- Monetary statistics reporting}

Information about the amount of money available in the economy is indispensable for the conduct of monetary policy. Electronic money issuers should therefore supply to the central bank with adequate statistical information.

\section{- Redeem ability}

Issuers of electronic money must be legally obliged, at request of the holders, to redeem electronic money against central bank money at par. This requirement ensures that the unit of account function of money is maintained. Furthermore, without a close link to central bank money, there could potentially be unlimited creation of electronic money, which could, in turn, lead to inflationary pressure.

\section{- Reserve Requirements}

The possibility must exist to impose reserve requirements on all issuers of electronic money, in particular in order to be prepared for a substantial growth of electronic money with a material impact on monetary policy. Such a reserve requirement could limit the risk of unrestricted growth in electronic money and help to maintain price stability. Furthermore, it ensures equal treatment in comparison with issuers of other forms of money.

${ }^{7}$ Conventionally a "divisia monetary aggregate index" is a simple sum index in which all monetary components are assigned the same weight (Thornton and Yue, 2009). 


\section{Acknowledgements}

We thank our colleagues from the Bank of Tanzania who provided insight and expertise that greatly assisted the completion and publication of this paper. We would also like to extend our gratitude to reviewers for their comments provided during the course of this research. We are also immensely grateful to management of the Bank for their support, although any errors are our own and should not tarnish the reputations of Bank.

\section{Conflicts of Interest}

The authors declare no conflicts of interest regarding the publication of this paper.

\section{References}

Adam, C., Nyella, J. J., Kessy, P., \& O’Connell, S. A. (2011). The Demand for Money in Tanzania. Tanzanian Economic Review, 2, 1-34.

Amromin, G., \& Chakravorti, S. (2009). Whither Loose Change? The Diminishing Demand for Small-Denomination Currency. Journal of Money, Credit and Banking, 41, 315-335. https://ideas.repec.org/a/mcb/jmoncb/v41y2009i2-3p315-335.html https://doi.org/10.1111/j.1538-4616.2009.00207.x

Attanasio, O., Guiso, L., \& Jappelli, T. (2002). The Demand for Money, Financial Innovation, and the Welfare Cost of Inflation: An Analysis with Household Data. Journal of Political Economy, 110, 317-351.

https://EconPapers.repec.org/RePEc:ucp:jpolec:v:110:y:2002:i:2:p:317-351 https://doi.org/10.1086/338743

Baumol, W. J. (1952). The Transactions Demand for Cash: An Inventory Theoretic Approach. The Quarterly Journal of Economics, 66, 545-556. https://doi.org/10.2307/1882104

Bhattacharyya, D. K. (1999). On the Economic Rationale of Estimating the Hidden Economy. The Economic Journal, 109, 348-359. https://doi.org/10.1111/1468-0297.00438

Boeschoten, W. C. (1992). Currency Use and Payment Patterns. Boston, MA: Kluwer Academic Publishers Dordrecht. https://doi.org/10.1007/978-94-011-2518-5

Bounie, D., \& François, A. (2006). Cash, Check or Bank Card? The Effects of Transaction Characteristics on the Use of Payment Instruments. Telecom Paris Economics and Social Sciences Working Paper No. ESS-06-05. https://doi.org/10.2139/ssrn.891791

Cusbert, T., \& Rohling, T. (2013). Currency Demand during the Global Financial Crisis: Evidence from Australia. SSRN. https://doi.org/10.2139/ssrn.2209604

Cuthbertson, K., Barlow, D., \& Taylor, M. P. (1991). Money Demand Analysis: An Outline in Money and Financial Markets. Cambridge: Basil Blackwell, Inc.

Drehmann, M., \& Goodhart, C. (2000). Is Cash Becoming Technologically Outmoded? Or Does It Remain Necessary to Facilitate "Bad Behaviour"? An Empirical Investigation into the Determinants of Cash Holdings. UK: LSE Financial Markets Group.

Drehmann, M., Goodhart, C., \& Krueger, M. (2002). The Challenges Facing Currency Usage: Will the Traditional Transaction Medium Be Able to Resist Competition from the New Technologies? Economic Policy, 17, 193-228.

https://doi.org/10.1111/1468-0327.00087

Duca, J. V., \& VanHoose, D. D. (2004). Recent Developments in Understanding the De- 
mand for Money. Journal of Economics and Business, 56, 247-272. https://doi.org/10.1016/j.jeconbus.2004.01.001

Giles, D. E. (1999). Measuring the Hidden Economy: Implications for Econometric Modelling. The Economic Journal, 109, 370-380. https://doi.org/10.1111/1468-0297.00440

Goodhart, C., \& Ashworth, J. (2014). Trying to Glimpse the “Grey Economy”. Vox-CEPR's Policy Portal. https://voxeu.org/article/trying-glimpse-grey-economy

Johansen, S. (1988). Statistical Analysis of Cointegration Vectors. Journal of Economic Dynamics and Control, 12, 231-254. https://doi.org/10.1016/0165-1889(88)90041-3

Johansen, S., \& Juselius, K. (1990). Maximum Likelihood Estimation and Inference on Cointegration-With Applications to the Demand for Money. Oxford Bulletin of Economics and Statistics, 52, 169-210.

https://doi.org/10.1111/j.1468-0084.1990.mp52002003.x

Judd, J. P., \& Scadding, J. L. (1982). The Search for a Stable Money Demand Function: A Survey of the Post-1973 Literature. Journal of Economic Literature, 20, 993-1023.

Lippi, F., \& Secchi, A. (2009). Technological Change and the Households' Demand for Currency. Journal of Monetary Economics, 56, 222-230.

https://doi.org/10.1016/j.jmoneco.2008.11.001

Lucas, R. E. (1980). Equilibrium in a Pure Currency Economy. Economic Inquiry, 18, 203-220. https://doi.org/10.1111/j.1465-7295.1980.tb00570.x

Lyssiotou, P., Pashardes, P., \& Stengos, T. (2004). Estimates of the Black Economy Based on Consumer Demand Approaches. The Economic Journal, 114, 622-640.

https://doi.org/10.1111/j.1468-0297.2004.00234.x

Rinaldi, L. (2001). Payment Cards and Money Demand in Belgium. Discussion Paper Series 01.16 .

Rogoff, K. (1998). Large Banknotes. Economic Policy, 26. https://scholar.harvard.edu/files/rogoff/files/c13431.pdf

Santomero, A. M., \& Seater, J. J. (1996). Alternative Monies and the Demand for Media of Exchange. Journal of Money, Credit and Banking, 28, 942-960. https://doi.org/10.2307/2077930

Sargent, T. J., \& Wallace, N. (1982). The Real-Bills Doctrine versus the Quantity Theory: A Reconsideration. Journal of Political Economy, 90, 1212-1236.

https://doi.org/10.1086/261118

Schneider, F., \& Bajada, C. (2005). An International Comparison of Underground Economic Activity. In F. Schneider (Ed.), Size, Causes and Consequences of the Underground Economy: An International Perspective (pp. 73-106). London: Routledge. https://doi.org/10.4324/9781351149044-5

Snellman, J. S., Vesala, J. M., \& Humphrey, D. B. (2001). Substitution of Noncash Payment Instruments for Cash in Europe. Journal of Financial Services Research, 19, 131145. https://doi.org/10.1023/A:1011151219545

Sprenkle, C. M. (1993). The Case of the Missing Currency. Journal of Economic Perspectives, 7, 175-184. https://doi.org/10.1257/jep.7.4.175

Sriram, M. S. S. (1999). Survey of Literature on Demand for Money: Theoretical and Empirical Work with Special Reference to Error-Correction Models. International Monetary Fund.

Stix, H. (2004). How Do Debit Cards Affect Cash Demand? Survey Data Evidence. Empirica, 31, 93-115. https://doi.org/10.1007/s10663-004-1079-y

Tanzi, V. (1982). The Underground Economy in the United States and Abroad. New 
York: Free Press.

Tobin, J. (1956). The Interest-Elasticity of Transactions Demand for Cash. The Review of Economics and Statistics, 38, 241-247. https://doi.org/10.2307/1925776

Tobin, J. (1958). Liquidity Preference as Behavior towards Risk. The Review of Economic Studies, 25, 65-86. https://doi.org/10.2307/2296205

Whitesell, W. C. (1992). Deposit Banks and the Market for Payment Media. Journal of Money, Credit and Banking, 24, 483-498. https://doi.org/10.2307/1992806

Yilmazkuday, H., \& Yazgan, M. E. (2009). Effects of Credit and Debit Cards on the Currency Demand. Applied Economics, 41, 2115-2123.

https://doi.org/10.1080/00036840701222496 
Appendix 1. Diagnostic Tests

Appendix 1.1. Descriptive Statistics

\begin{tabular}{|c|c|c|c|c|c|c|c|c|c|c|c|}
\hline & 1000 & 2000 & 5000 & 10,000 & All CC & $\begin{array}{c}\text { GDP } \\
\text { Official }\end{array}$ & $\begin{array}{l}\text { GDP } \\
\text { Grey }\end{array}$ & CPI & E/Rate & Mobile & $\begin{array}{l}\text { Tbills } \\
\text { rate }\end{array}$ \\
\hline Mean & 4.758165 & 5.031311 & 6.380310 & 7.937981 & 8.238187 & 8.988559 & 6.683888 & 4.591369 & 4.735421 & 7.083332 & 8.415516 \\
\hline Median & 4.871792 & 5.100334 & 6.484146 & 8.008289 & 8.312181 & 9.047734 & 6.696064 & 4.600508 & 4.748293 & 7.120222 & 8.060000 \\
\hline Maximum & 5.074341 & 5.559211 & 6.671390 & 8.260333 & 8.511428 & 9.368814 & 7.356289 & 4.764153 & 4.886083 & 7.805533 & 13.94000 \\
\hline Minimum & 4.266829 & 4.558504 & 5.855050 & 7.520693 & 7.813740 & 8.474494 & 6.171622 & 4.347385 & 4.609195 & 5.612932 & 1.914067 \\
\hline Std. Dev. & 0.222490 & 0.214379 & 0.213912 & 0.201904 & 0.196858 & 0.269486 & 0.293091 & 0.117486 & 0.068318 & 0.527441 & 3.780757 \\
\hline Skewness & -0.810537 & -0.108837 & -0.674878 & -0.574395 & -0.650152 & -0.286214 & 0.187218 & -0.299550 & -0.216364 & -0.725128 & -0.109577 \\
\hline Kurtosis & 2.224698 & 2.787253 & 2.301580 & 2.143121 & 2.183972 & 1.843839 & 2.282394 & 1.928257 & 2.466502 & 3.164514 & 1.613256 \\
\hline Jarque-Bera & 12.51227 & 0.358991 & 8.949829 & 7.959093 & 9.132181 & 6.449476 & 2.538749 & 5.841769 & 1.828511 & 8.254951 & 7.637962 \\
\hline Probability & 0.001919 & 0.835692 & 0.011391 & 0.018694 & 0.010399 & 0.039766 & 0.281007 & 0.053886 & 0.400815 & 0.016124 & 0.021950 \\
\hline Sum & 442.5093 & 467.9119 & 593.3689 & 738.2323 & 766.1514 & 835.9360 & 621.6016 & 426.9973 & 440.3941 & 658.7499 & 782.6430 \\
\hline Sum Sq. Dev. & 4.554156 & 4.228168 & 4.209785 & 3.750383 & 3.565281 & 6.681274 & 7.902988 & 1.269872 & 0.429392 & 25.59389 & 1315.059 \\
\hline
\end{tabular}


Appendix 1.2. Unit Root Tests

Appendix 1.2.1. Test in Levels

1) Currency: 1000 notes

\begin{tabular}{llll}
\hline & & Adj. t-Stat & Prob. $^{*}$ \\
\hline Phillips-Perron test statistic & & -2.139337 & 0.2301 \\
\hline Test critical values: & $1 \%$ level & -3.503049 & \\
& 5\% level & -2.893230 & \\
& & & \\
& $10 \%$ level & -2.583740 & \\
\hline
\end{tabular}

${ }^{\star}$ MacKinnon (1996) one-sided p-values.

Residual variance (no correction)

0.001089

HAC corrected variance (Bartlett kernel)

0.000979

Phillips-Perron Test Equation

Dependent Variable: D(L_N1)

Method: Least Squares

Date: $12 / 23 / 19 \quad$ Time: $14: 11$

Sample (adjusted): 2012M02 2019M09

Included observations: 92 after adjustments

\begin{tabular}{lcccc}
\hline \multicolumn{1}{c}{ Variable } & Coefficient & Std. Error & t-Statistic & Prob. \\
\hline \multicolumn{1}{c}{ L_N1(-1) } & -0.032902 & 0.015664 & -2.100531 & 0.0385 \\
& 0.162843 & 0.074589 & 2.183200 & 0.0316 \\
\hline R-squared & 0.046734 & Mean dependent var & 0.006337 \\
Adjusted R-squared & 0.036142 & S. D. dependent var & 0.033986 \\
S. E. of regression & 0.033367 & Akaike info criterion & -3.941027 \\
Sum squared resid & 0.100199 & Schwarz criterion & -3.886206 \\
Log likelihood & 183.2872 & Hannan-Quinn criter. & -3.918901 \\
F-statistic & 4.412232 & Durbin-Watson stat & 2.040940 \\
Prob (F-statistic) & 0.038479 & & \\
\hline
\end{tabular}




\section{2) Currency: 2000 notes}

\begin{tabular}{llll}
\hline & & Adj. t-Stat & Prob. $^{*}$ \\
\hline Phillips-Perron test statistic & & -0.968934 & 0.7615 \\
\hline Test critical values: & $1 \%$ level & -3.503049 & \\
& $5 \%$ level & -2.893230 & \\
& $10 \%$ level & -2.583740 & \\
\hline
\end{tabular}

*MacKinnon (1996) one-sided p-values.

Residual variance (no correction)

0.003114

HAC corrected variance (Bartlett kernel)

0.003889

Phillips-Perron Test Equation

Dependent Variable: D(L_N2)

Method: Least Squares

Date: $12 / 23 / 19$ Time: 14:23

Sample (adjusted): 2012M02 2019M09

Included observations: 92 after adjustments

\begin{tabular}{lcccc}
\hline \multicolumn{1}{l}{ Variable } & Coefficient & Std. Error & t-Statistic & Prob. \\
\hline \multicolumn{1}{c}{ L_N2(-1) } & -0.021625 & 0.028403 & -0.761356 & 0.4484 \\
& & & 0.831522 & 0.4079 \\
\hline R-squared & 0.118792 & 0.142861 & 0.010116 \\
Adjusted R-squared & 0.006399 & Mean dependent var & 0.056294 \\
S. E. of regression & -0.004641 & S. D. dependent var & -2.890342 \\
Sum squared resid & 0.056424 & Akaike info criterion & -2.835521 \\
Log likelihood & 0.286531 & Schwarz criterion & -2.868216 \\
F-statistic & 134.9557 & Hannan-Quinn criter. & 1.488378 \\
Prob (F-statistic) & 0.579663 & Durbin-Watson stat & \\
\hline & & & \\
\hline
\end{tabular}




\section{3) Currency: 5000 notes}

\begin{tabular}{llll}
\hline & & Adj. t-Stat & Prob. $^{*}$ \\
\hline Phillips-Perron test statistic & & -2.205882 & 0.2057 \\
\hline Test critical values: & $1 \%$ level & -3.503049 & \\
& 5\% level & -2.893230 & \\
& & & \\
& & -2.583740 & \\
\hline
\end{tabular}

${ }^{\star}$ MacKinnon (1996) one-sided p-values.

Residual variance (no correction)

0.003188

HAC corrected variance (Bartlett kernel)

0.003188

Phillips-Perron Test Equation

Dependent Variable: D(L_N5)

Method: Least Squares

Date: 12/23/19 Time: 14:31

Sample (adjusted): 2012M02 2019M09

Included observations: 92 after adjustments

\begin{tabular}{lcccc}
\hline \multicolumn{1}{l}{ Variable } & Coefficient & Std. Error & t-Statistic & Prob. \\
\hline \multicolumn{1}{c}{ L_N5(-1) } & -0.061550 & 0.027903 & -2.205882 & 0.0299 \\
& 0.399456 & 0.178080 & 2.243124 & 0.0273 \\
\hline R-squared & 0.051293 & Mean dependent var & 0.006852 \\
Adjusted R-squared & 0.040751 & S. D. dependent var & 0.058288 \\
S. E. of regression & 0.057088 & Akaike info criterion & -2.866953 \\
Sum squared resid & 0.293312 & Schwarz criterion & -2.812132 \\
Log likelihood & 133.8799 & Hannan-Quinn criter. & -2.844827 \\
F-statistic & 4.865915 & Durbin-Watson stat & 1.287183 \\
Prob (F-statistic) & 0.029939 & & \\
\hline
\end{tabular}




\section{4) Currency: 10,000 notes}

\begin{tabular}{llll}
\hline & & Adj. t-Stat & Prob. $^{*}$ \\
\hline Phillips-Perron test statistic & & -1.339203 & 0.6084 \\
\hline Test critical values: & $1 \%$ level & -3.503049 & \\
& 5\% level & -2.893230 & \\
& $10 \%$ level & -2.583740 & \\
\hline
\end{tabular}

${ }^{*}$ MacKinnon (1996) one-sided p-values.

Residual variance (no correction)

0.000706

HAC corrected variance (Bartlett kernel)

0.000677

Phillips-Perron Test Equation

Dependent Variable: D(L_N10)

Method: Least Squares

Date: 12/23/19 Time: 14:36

Sample (adjusted): 2012M02 2019M09

Included observations: 92 after adjustments

\begin{tabular}{lcccc}
\multicolumn{1}{c}{ Variable } & Coefficient & Std. Error & t-Statistic & Prob. \\
\hline \multicolumn{1}{c}{ L_N10(-1) } & -0.018820 & 0.014069 & -1.337715 & 0.1844 \\
& & & & \\
\multicolumn{1}{c}{ C } & 0.157364 & 0.111661 & 1.409294 & 0.1622 \\
\hline R-squared & 0.019495 & Mean dependent var & 0.008040 \\
Adjusted R-squared & 0.008601 & S. D. dependent var & 0.026977 \\
S. E. of regression & 0.026861 & Akaike info criterion & -4.374804 \\
Sum squared resid & 0.064935 & Schwarz criterion & -4.319983 \\
Log likelihood & 203.2410 & Hannan-Quinn criter. & -4.352678 \\
F-statistic & 1.789482 & Durbin-Watson stat & 2.078590 \\
Prob (F-statistic) & 0.184360 & & \\
\hline
\end{tabular}




\section{5) All cash}

\begin{tabular}{llll}
\hline & & Adj.t-Stat & Prob.* $^{*}$ \\
\hline Phillips-Perron test statistic & & -1.674705 & 0.4406 \\
\hline Test critical values: & $1 \%$ level & -3.503049 & \\
& $5 \%$ level & -2.893230 & \\
& $10 \%$ level & -2.583740 & \\
\hline
\end{tabular}

*MacKinnon (1996) one-sided p-values.

Residual variance (no correction)

0.000794

HAC corrected variance (Bartlett kernel)

0.000844

Phillips-Perron Test Equation

Dependent Variable: D(L_CC)

Method: Least Squares

Date: $12 / 23 / 19 \quad$ Time: 14:47

Sample (adjusted): 2012M02 2019M09

Included observations: 92 after adjustments

\begin{tabular}{lcccc}
\hline \multicolumn{1}{c}{ Variable } & Coefficient & Std. Error & t-Statistic & Prob. \\
\hline \multicolumn{1}{c}{ L_CC(-1) } & -0.025671 & 0.015254 & -1.682897 & 0.0959 \\
& 0.218952 & 0.125654 & 1.742490 & 0.0848 \\
\hline R-squared & 0.030508 & Mean dependent var & 0.007547 \\
Adjusted R-squared & 0.019736 & S. D. dependent var & 0.028781 \\
S. E. of regression & 0.028496 & Akaike info criterion & -4.256616 \\
Sum squared resid & & & -4.201794 \\
Log likelihood & 0.073081 & Schwarz criterion & -4.234489 \\
F-statistic & 197.8043 & Hannan-Quinn criter. & 1.868165 \\
Prob (F-statistic) & 2.832141 & Durbin-Watson stat & \\
\hline
\end{tabular}




\section{6) GDP (Official)}

\begin{tabular}{llll}
\hline & & Adj. t-Stat & Prob. $^{*}$ \\
\hline Phillips-Perron test statistic & & -1.072235 & 0.7239 \\
\hline Test critical values: & $1 \%$ level & -3.503049 & \\
& 5\% level & -2.893230 & \\
& $10 \%$ level & -2.583740 & \\
\hline
\end{tabular}

${ }^{*}$ MacKinnon (1996) one-sided p-values.

Residual variance (no correction)

0.001314

HAC corrected variance (Bartlett kernel)

0.000681

Phillips-Perron Test Equation

Dependent Variable: D(L_RGDP15)

Method: Least Squares

Date: 12/23/19 Time: 15:01

Sample (adjusted): 2012M02 2019M09

Included observations: 92 after adjustments

\begin{tabular}{lcccc}
\multicolumn{1}{c}{ Variable } & Coefficient & Std. Error & t-Statistic & Prob. \\
\hline \multicolumn{1}{c}{ L_RGDP15(-1) } & -0.033599 & 0.025322 & -1.326834 & 0.1879 \\
& & & & \\
\multicolumn{1}{c}{ C } & 0.305901 & 0.227737 & 1.343222 & 0.1826 \\
\hline R-squared & 0.019186 & Mean dependent var & 0.003775 \\
Adjusted R-squared & 0.008288 & S. D. dependent var & 0.036804 \\
S. E. of regression & 0.036651 & Akaike info criterion & -3.753265 \\
Sum squared resid & 0.120895 & Schwarz criterion & -3.698443 \\
Log likelihood & 174.6502 & Hannan-Quinn criter. & -3.731138 \\
F-statistic & 1.760487 & Durbin-Watson stat & 0.841955 \\
Prob (F-statistic) & 0.187920 & & \\
\hline
\end{tabular}




\section{7) GDP (Grey)}

Null Hypothesis: L_BLACKREV has a unit root

Exogenous: Constant

Bandwidth: 6 (Newey-West automatic) using Bartlett kernel

\begin{tabular}{llll}
\hline & & Adj. t-Stat & Prob. $^{*}$ \\
\hline Phillips-Perron test statistic & & 0.379457 & 0.9811 \\
\hline Test critical values: & $1 \%$ level & -3.503049 & \\
& $5 \%$ level & -2.893230 & \\
& $10 \%$ level & -2.583740 & \\
\hline
\end{tabular}

${ }^{*}$ MacKinnon (1996) one-sided p-values.

\begin{tabular}{ll}
\hline Residual variance (no correction) & 0.002351 \\
HAC corrected variance (Bartlett kernel) & 0.001209 \\
\hline
\end{tabular}

Phillips-Perron Test Equation

Dependent Variable: D(L_BLACKREV)

Method: Least Squares

Date: 12/23/19 Time: 15:03

Sample (adjusted): 2012M02 2019M09

Included observations: 92 after adjustments

\begin{tabular}{lcccc}
\hline \multicolumn{1}{c}{ Variable } & Coefficient & Std. Error & t-Statistic & Prob. \\
\hline \multicolumn{1}{c}{ L_BLACKREV(-1) } & -0.002207 & 0.017887 & -0.123412 & 0.9021 \\
& 0.026424 & 0.119541 & 0.221046 & 0.8256 \\
\hline R-squared & 0.000169 & Mean dependent var & 0.011685 \\
Adjusted R-squared & -0.010940 & S. D. dependent var & 0.048759 \\
S. E. of regression & 0.049025 & Akaike info criterion & -3.171494 \\
Sum squared resid & 0.216306 & Schwarz criterion & -3.116672 \\
Log likelihood & 147.8887 & Hannan-Quinn criter. & -3.149367 \\
F-statistic & 0.015230 & Durbin-Watson stat & 1.835561 \\
Prob (F-statistic) & 0.902056 & & \\
\hline
\end{tabular}




\section{8) T-Bills Rate}

\begin{tabular}{llll}
\hline & & Adj. t-Stat & Prob. $^{*}$ \\
\hline Phillips-Perron test statistic & & -1.010947 & 0.7467 \\
\hline Test critical values: & $1 \%$ level & -3.503049 & \\
& $5 \%$ level & -2.893230 & \\
& $10 \%$ level & -2.583740 & \\
\hline
\end{tabular}

*MacKinnon (1996) one-sided p-values.

Residual variance (no correction)

$5.87 \mathrm{E}-05$

HAC corrected variance (Bartlett kernel)

$4.48 \mathrm{E}-05$

Phillips-Perron Test Equation

Dependent Variable: D(R_3REV)

Method: Least Squares

Date: 12/23/19 Time: 15:05

Sample (adjusted): 2012M02 2019M09

Included observations: 92 after adjustments

\begin{tabular}{lcccc}
\multicolumn{1}{c}{ Variable } & Coefficient & Std. Error & t-Statistic & Prob. \\
\hline \multicolumn{1}{c}{ R_3REV(-1) } & -0.023942 & 0.021479 & -1.114696 & 0.2679 \\
& 0.001087 & 0.001988 & 0.546996 & 0.5857 \\
\hline R-squared & 0.013618 & Mean dependent var & -0.000938 \\
Adjusted R-squared & 0.002658 & S. D. dependent var & 0.007754 \\
S. E. of regression & 0.007744 & Akaike info criterion & -6.862368 \\
Sum squared resid & & & -6.807546 \\
Log likelihood & 0.005397 & Schwarz criterion & -6.840242 \\
F-statistic & 317.6689 & Hannan-Quinn criter. & 1.545287 \\
Prob (F-statistic) & 1.242547 & Durbin-Watson stat & \\
\hline
\end{tabular}




\section{9) $1.2 .9 \mathrm{CPI}$}

Null Hypothesis: L_CPI has a unit root

Exogenous: Constant

Bandwidth: 3 (Newey-West automatic) using Bartlett kernel

\begin{tabular}{|c|c|c|c|}
\hline & & Adj. t-Stat & Prob. ${ }^{*}$ \\
\hline Phillips-Perron test statistic & & -2.211630 & 0.2037 \\
\hline \multirow[t]{3}{*}{ Test critical values: } & $1 \%$ level & -3.503049 & \\
\hline & $5 \%$ level & -2.893230 & \\
\hline & $10 \%$ level & -2.583740 & \\
\hline
\end{tabular}

${ }^{\star}$ MacKinnon (1996) one-sided p-values.

Residual variance (no correction)

$3.28 \mathrm{E}-05$

HAC corrected variance (Bartlett kernel)

$6.45 \mathrm{E}-05$

Phillips-Perron Test Equation

Dependent Variable: D(L_CPI)

Method: Least Squares

Date: $12 / 23 / 19$ Time: 15:07

Sample (adjusted): 2012M02 2019M09

Included observations: 92 after adjustments

\begin{tabular}{lcccc}
\multicolumn{1}{c}{ Variable } & Coefficient & Std. Error & t-Statistic & Prob. \\
\multicolumn{1}{c}{ L_CPI(-1) } & -0.014918 & 0.005189 & -2.874756 & 0.0050 \\
\multicolumn{1}{c}{ C } & 0.072877 & 0.023825 & 3.058822 & 0.0029 \\
R-squared & 0.084102 & Mean dependent var & 0.004407 \\
Adjusted R-squared & 0.073925 & S. D. dependent var & 0.006013 \\
S. E. of regression & 0.005787 & Akaike info criterion & -7.444947 \\
Sum squared resid & 0.003014 & Schwarz criterion & -7.390125 \\
Log likelihood & 344.4675 & Hannan-Quinn criter. & -7.422820 \\
F-statistic & 8.264222 & Durbin-Watson stat & 0.947078 \\
Prob (F-statistic) & 0.005046 & &
\end{tabular}




\section{0) Value of Mobile Transactions}

\begin{tabular}{lccc}
\hline & & Adj. t-Stat & Prob. $^{*}$ \\
\hline Phillips-Perron test statistic & & 2.272400 & 0.9992 \\
\hline Test critical values: & $1 \%$ level & -2.590340 & \\
& $5 \%$ level & -1.944364 \\
& $10 \%$ level & -1.614441 \\
\hline
\end{tabular}

${ }^{*}$ MacKinnon (1996) one-sided p-values.

Residual variance (no correction)

0.008384

HAC corrected variance (Bartlett kernel)

0.004797

Phillips-Perron Test Equation

Dependent Variable: D(L_MOBVREV)

Method: Least Squares

Date: 12/23/19 Time: 15:16

Sample (adjusted): 2012M02 2019M09

Included observations: 92 after adjustments

\begin{tabular}{lcccc}
\hline \multicolumn{1}{c}{ Variable } & Coefficient & Std. Error & t-Statistic & Prob. \\
\hline \multicolumn{1}{c}{ L_MOBVREV(-1) } & 0.003006 & 0.001353 & 2.221984 & 0.0288 \\
\hline R-squared & -0.010604 & Mean dependent var & 0.023299 \\
Adjusted R-squared & -0.010604 & S. D. dependent var & 0.091582 \\
S. E. of regression & 0.092066 & Akaike info criterion & -1.921815 \\
Sum squared resid & & & -1.894404 \\
Log likelihood & 0.771327 & Schwarz criterion & -1.910752 \\
Durbin-Watson stat & 89.40348 & Hannan-Quinn criter. & \\
\hline
\end{tabular}


11) Exchange Rate

\begin{tabular}{lccc}
\hline & & Adj. t-Stat & Prob. $^{*}$ \\
\hline Phillips-Perron test statistic & & -0.411639 & 0.5325 \\
\hline Test critical values: & 1\% level & -2.590340 & \\
& $5 \%$ level & -1.944364 \\
& & \\
& & \\
& & -1.614441 \\
\hline
\end{tabular}

*MacKinnon (1996) one-sided p-values.

Residual variance (no correction)

0.000647

HAC corrected variance (Bartlett kernel)

0.000751

Phillips-Perron Test Equation

Dependent Variable: D(L_NEERREV)

Method: Least Squares

Date: 12/23/19 Time: 15:20

Sample (adjusted): 2012M02 2019M09

Included observations: 92 after adjustments

\begin{tabular}{lcccc}
\hline \multicolumn{1}{c}{ Variable } & Coefficient & Std. Error & t-Statistic & Prob. \\
\hline \multicolumn{1}{c}{ L_NEERREV(-1) } & -0.000247 & 0.000563 & -0.439236 & 0.6615 \\
\hline R-squared & 0.000318 & Mean dependent var & -0.001080 \\
Adjusted R-squared & 0.000318 & S. D. dependent var & 0.025587 \\
S. E. of regression & & & -4.482952 \\
Sum squared resid & 0.025583 & Akaike info criterion & -4.455541 \\
Log likelihood & 0.059559 & Schwarz criterion & -4.471889 \\
Durbin-Watson stat & 207.2158 & Hannan-Quinn criter. & \\
\hline
\end{tabular}


Appendix 1.2.2. Test in 1st Difference

1) Cash: 1000 notes

Null Hypothesis: D(L_N1) has a unit root

Exogenous: Constant

Bandwidth: 3 (Newey-West automatic) using Bartlett kernel

\begin{tabular}{llll}
\hline & & Adj. t-Stat & Prob. $^{*}$ \\
\hline Phillips-Perron test statistic & & -9.605673 & 0.0000 \\
\hline Test critical values: & $1 \%$ level & -3.503879 & \\
& 5\% level & -2.893589 & \\
& & & \\
& & & \\
& & -2.583931 & \\
\hline
\end{tabular}

${ }^{*}$ MacKinnon (1996) one-sided p-values.

Residual variance (no correction)

0.001140

HAC corrected variance (Bartlett kernel)

0.001171

Phillips-Perron Test Equation

Dependent Variable: D(L_N1,2)

Method: Least Squares

Date: $12 / 29 / 19$ Time: 10:23

Sample (adjusted): 2012M03 2019M09

Included observations: 91 after adjustments

\begin{tabular}{lcccc}
\hline \multicolumn{1}{c}{ Variable } & Coefficient & Std. Error & t-Statistic & Prob. \\
\hline \multicolumn{1}{c}{ D(L_N1(-1)) } & -1.013809 & 0.105536 & -9.606271 & 0.0000 \\
\hline \multicolumn{1}{c}{0.006825} & 0.003646 & 1.872051 & 0.0645 \\
R-squared & 0.509048 & Mean dependent var & 0.000171 \\
Adjusted R-squared & 0.503532 & S. D. dependent var & 0.048460 \\
S. E. of regression & & & -3.894640 \\
Sum squared resid & 0.034145 & Akaike info criterion & -3.839456 \\
Log likelihood & 0.103766 & Schwarz criterion & -3.872377 \\
F-statistic & 179.2061 & Hannan-Quinn criter. & 2.004784 \\
Prob (F-statistic) & 92.28045 & Durbin-Watson stat & \\
\hline
\end{tabular}




\section{2) Cash: 2000 notes}

Null Hypothesis: D(L_N2) has a unit root

Exogenous: Constant

Bandwidth: 1 (Newey-West automatic) using Bartlett kernel

\begin{tabular}{lccc}
\hline & & Adj. t-Stat & Prob. $^{*}$ \\
\hline Phillips-Perron test statistic & & -7.437614 & 0.0000 \\
\hline Test critical values: & $1 \%$ level & -3.503879 \\
& $5 \%$ level & -2.893589 \\
& $10 \%$ level & -2.583931 \\
\hline
\end{tabular}

${ }^{\star}$ MacKinnon (1996) one-sided p-values.

Residual variance (no correction)

0.002955

HAC corrected variance (Bartlett kernel)

0.002971

Phillips-Perron Test Equation

Dependent Variable: D(L_N2,2)

Method: Least Squares

Date: $12 / 29 / 19$ Time: 10:25

Sample (adjusted): 2012M03 2019M09

Included observations: 91 after adjustments

\begin{tabular}{lcccc}
\hline \multicolumn{1}{c}{ Variable } & Coefficient & Std. Error & t-Statistic & Prob. \\
\multicolumn{1}{c}{ D(L_N2(-1)) } & -0.760752 & 0.102352 & -7.432709 & 0.0000 \\
\hline R-squared & 0.008291 & 0.005854 & 1.416158 & 0.1602 \\
Adjusted R-squared & 0.382995 & Mean dependent var & 0.000581 \\
S. E. of regression & 0.376062 & S. D. dependent var & 0.069583 \\
Sum squared resid & 0.054963 & Akaike info criterion & -2.942565 \\
Log likelihood & 0.268867 & Schwarz criterion & -2.887381 \\
F-statistic & 135.8867 & Hannan-Quinn criter. & -2.920302 \\
Prob (F-statistic) & 55.24516 & Durbin-Watson stat & 1.988213 \\
& & &
\end{tabular}




\section{3) Cash: 5000 notes}

Null Hypothesis: D(L_N5) has a unit root

Exogenous: Constant

Bandwidth: 4 (Newey-West automatic) using Bartlett kernel

\begin{tabular}{|c|c|c|c|}
\hline & & Adj. t-Stat & Prob.* \\
\hline Phillips-Perron test statistic & & -6.409838 & 0.0000 \\
\hline \multirow[t]{3}{*}{ Test critical values: } & $1 \%$ level & -3.503879 & \\
\hline & $5 \%$ level & -2.893589 & \\
\hline & $10 \%$ level & -2.583931 & \\
\hline
\end{tabular}

${ }^{*}$ MacKinnon (1996) one-sided p-values.

Residual variance (no correction)

0.002975

HAC corrected variance (Bartlett kernel)

0.002639

Phillips-Perron Test Equation

Dependent Variable: D(L_N5,2)

Method: Least Squares

Date: $12 / 29 / 19$ Time: 10:27

Sample (adjusted): 2012M03 2019M09

Included observations: 91 after adjustments

\begin{tabular}{lcccc}
\hline \multicolumn{1}{c}{ Variable } & Coefficient & Std. Error & t-Statistic & Prob. \\
\hline \multicolumn{1}{c}{ D(L_N5(-1)) } & -0.652065 & 0.099649 & -6.543588 & 0.0000 \\
& 0.004669 & 0.005829 & 0.800966 & 0.4253 \\
\hline R-squared & 0.324829 & Mean dependent var & -0.000179 \\
Adjusted R-squared & 0.317243 & S. D. dependent var & 0.066747 \\
S. E. of regression & 0.055153 & Akaike info criterion & -2.935694 \\
Sum squared resid & 0.270721 & Schwarz criterion & -2.880510 \\
Log likelihood & 135.5741 & Hannan-Quinn criter. & -2.913431 \\
F-statistic & & & \\
Prob (F-statistic) & 42.81855 & Durbin-Watson stat & 1.893317 \\
\hline
\end{tabular}




\section{4) Cash: 10,000 notes}

Null Hypothesis: D(L_N10) has a unit root

Exogenous: Constant

Bandwidth: 0 (Newey-West automatic) using Bartlett kernel

\begin{tabular}{|c|c|c|c|}
\hline & & Adj. t-Stat & Prob. ${ }^{*}$ \\
\hline Phillips-Perron test statistic & & -9.805208 & 0.0000 \\
\hline \multirow[t]{3}{*}{ Test critical values: } & $1 \%$ level & -3.503879 & \\
\hline & $5 \%$ level & -2.893589 & \\
\hline & $10 \%$ level & -2.583931 & \\
\hline
\end{tabular}

${ }^{\star}$ MacKinnon (1996) one-sided p-values.

Residual variance (no correction)

0.000727

HAC corrected variance (Bartlett kernel)

0.000727

Phillips-Perron Test Equation

Dependent Variable: D(L_N10,2)

Method: Least Squares

Date: $12 / 29 / 19$ Time: $10: 28$

Sample (adjusted): 2012M03 2019M09

Included observations: 91 after adjustments

\begin{tabular}{lcccc}
\hline \multicolumn{1}{c}{ Variable } & Coefficient & Std. Error & t-Statistic & Prob. \\
\multicolumn{1}{c}{ D(L_N10(-1)) } & -1.038502 & 0.105913 & -9.805208 & 0.0000 \\
\hline R-squared & 0.008389 & 0.002981 & 2.814338 & 0.0060 \\
Adjusted R-squared & 0.519288 & Mean dependent var & $6.17 \mathrm{E}-05$ \\
S. E. of regression & 0.513887 & S. D. dependent var & 0.039092 \\
Sum squared resid & 0.027255 & Akaike info criterion & -4.345399 \\
Log likelihood & 0.066114 & Schwarz criterion & -4.290215 \\
F-statistic & 199.7156 & Hannan-Quinn criter. & -4.323136 \\
Prob (F-statistic) & 96.14210 & Durbin-Watson stat & 2.003520 \\
& &
\end{tabular}




\section{5) All cash}

Null Hypothesis: D(L_CC) has a unit root

Exogenous: Constant

Bandwidth: 1 (Newey-West automatic) using Bartlett kernel

\begin{tabular}{llll}
\hline & & Adj. t-Stat & Prob. $^{\star}$ \\
\hline Phillips-Perron test statistic & & -8.802901 & 0.0000 \\
\hline Test critical values: & $1 \%$ level & -3.503879 & \\
& $5 \%$ level & -2.893589 & \\
& $10 \%$ level & -2.583931 & \\
\hline
\end{tabular}

${ }^{*}$ MacKinnon (1996) one-sided p-values.

Residual variance (no correction)

0.000823

HAC corrected variance (Bartlett kernel)

0.000828

Phillips-Perron Test Equation

Dependent Variable: D(L_CC,2)

Method: Least Squares

Date: $12 / 29 / 19$ Time: 10:31

Sample (adjusted): 2012M03 2019M09

Included observations: 91 after adjustments

\begin{tabular}{lcccc}
\hline \multicolumn{1}{c}{ Variable } & Coefficient & Std. Error & t-Statistic & Prob. \\
\hline \multicolumn{1}{c}{ D(L_CC(-1)) } & -0.930108 & 0.105685 & -8.800787 & 0.0000 \\
& 0.007135 & 0.003146 & 2.268057 & 0.0257 \\
\hline R-squared & 0.465317 & Mean dependent var & $5.02 \mathrm{E}-05$ \\
Adjusted R-squared & 0.459310 & S. D. dependent var & 0.039450 \\
S. E. of regression & 0.029009 & Akaike info criterion & -4.220717 \\
Sum squared resid & 0.074893 & Schwarz criterion & -4.165533 \\
Log likelihood & 194.0426 & Hannan-Quinn criter. & -4.198454 \\
F-statistic & 77.45385 & Durbin-Watson stat & 1.987763 \\
Prob (F-statistic) & 0.000000 & & \\
\hline
\end{tabular}




\section{6) GDP (Official)}

Null Hypothesis: D(L_RGDP15) has a unit root

Exogenous: Constant

Bandwidth: 33 (Newey-West automatic) using Bartlett kernel

\begin{tabular}{lccc}
\hline & & Adj. t-Stat & Prob. $^{*}$ \\
\hline Phillips-Perron test statistic & & -4.211588 & 0.0011 \\
\hline Test critical values: & $1 \%$ level & -3.503879 & \\
& $5 \%$ level & -2.893589 & \\
& $10 \%$ level & -2.583931 & \\
\hline
\end{tabular}

${ }^{*}$ MacKinnon (1996) one-sided p-values.

Residual variance (no correction)

0.000909

HAC corrected variance (Bartlett kernel)

0.000114

Phillips-Perron Test Equation

Dependent Variable: D(L_RGDP15,2)

Method: Least Squares

Date: $12 / 29 / 19$ Time: 10:33

Sample (adjusted): 2012M03 2019M09

Included observations: 91 after adjustments

\begin{tabular}{lcccc}
\multicolumn{1}{c}{ Variable } & Coefficient & Std. Error & t-Statistic & Prob. \\
\hline \multicolumn{1}{c}{ D(L_RGDP15(-1)) } & -0.427994 & 0.087043 & -4.917043 & 0.0000 \\
\multicolumn{1}{c}{0.001686} & 0.003215 & 0.524362 & 0.6013 \\
\hline R-squared & 0.213623 & Mean dependent var & $-4.46 \mathrm{E}-05$ \\
Adjusted R-squared & 0.204788 & S. D. dependent var & 0.034185 \\
S. E. of regression & 0.030485 & Akaike info criterion & -4.121459 \\
Sum squared resid & 0.082708 & Schwarz criterion & -4.066276 \\
Log likelihood & 189.5264 & Hannan-Quinn criter. & -4.099196 \\
F-statistic & 24.17731 & Durbin-Watson stat & 1.156230 \\
Prob (F-statistic) & 0.000004 & & \\
\hline
\end{tabular}




\section{7) GDP (Grey)}

Null Hypothesis: D(L_BLACKREV) has a unit root

Exogenous: Constant

Bandwidth: 5 (Newey-West automatic) using Bartlett kernel

\begin{tabular}{llll}
\hline & & Adj. t-Stat & Prob. $^{\star}$ \\
\hline Phillips-Perron test statistic & & -8.959985 & 0.0000 \\
\hline Test critical values: & $1 \%$ level & -3.503879 & \\
& $5 \%$ level & -2.893589 & \\
& $10 \%$ level & -2.583931 & \\
\hline
\end{tabular}

${ }^{*}$ MacKinnon (1996) one-sided p-values.

Residual variance (no correction)

0.002364

HAC corrected variance (Bartlett kernel)

0.001102

Phillips-Perron Test Equation

Dependent Variable: D(L_BLACKREV,2)

Method: Least Squares

Date: $12 / 29 / 19$ Time: 10:40

Sample (adjusted): 2012M03 2019M09

Included observations: 91 after adjustments

\begin{tabular}{lcccc}
\hline \multicolumn{1}{c}{ Variable } & Coefficient & Std. Error & t-Statistic & Prob. \\
\hline \multicolumn{1}{c}{ D(L_BLACKREV(-1)) } & -0.932319 & 0.107242 & -8.693573 & 0.0000 \\
& 0.011127 & 0.005283 & 2.106221 & 0.0380 \\
\hline R-squared & 0.459224 & Mean dependent var & 0.001034 \\
Adjusted R-squared & 0.453148 & S. D. dependent var & 0.066484 \\
S. E. of regression & 0.049164 & Akaike info criterion & -3.165568 \\
Sum squared resid & 0.215124 & Schwarz criterion & -3.110384 \\
Log likelihood & 146.0334 & Hannan-Quinn criter. & -3.143305 \\
F-statistic & 75.57820 & Durbin-Watson stat & 1.940696 \\
Prob (F-statistic) & 0.000000 & & \\
\hline
\end{tabular}




\section{8) T-Bills Rate}

Null Hypothesis: D(R_3REV) has a unit root

Exogenous: Constant

Bandwidth: 12 (Newey-West automatic) using Bartlett kernel

\begin{tabular}{|c|c|c|c|}
\hline & & Adj. t-Stat & Prob.* \\
\hline Phillips-Perron test statistic & & -7.633468 & 0.0000 \\
\hline \multirow[t]{3}{*}{ Test critical values: } & $1 \%$ level & -3.503879 & \\
\hline & $5 \%$ level & -2.893589 & \\
\hline & $10 \%$ level & -2.583931 & \\
\hline
\end{tabular}

${ }^{\star}$ MacKinnon (1996) one-sided p-values.

Residual variance (no correction)

$5.66 \mathrm{E}-05$

HAC corrected variance (Bartlett kernel)

$2.44 \mathrm{E}-05$

Phillips-Perron Test Equation

Dependent Variable: D(R_3REV,2)

Method: Least Squares

Date: $12 / 29 / 19$ Time: 10:46

Sample (adjusted): 2012M03 2019M09

Included observations: 91 after adjustments

\begin{tabular}{lcccc}
\hline \multicolumn{1}{c}{ Variable } & Coefficient & Std. Error & t-Statistic & Prob. \\
\multicolumn{1}{c}{ D(R_3REV(-1)) } & -0.787383 & 0.102952 & -7.648041 & 0.0000 \\
\hline R-squared & -0.000640 & 0.000804 & -0.796507 & 0.4279 \\
Adjusted R-squared & 0.396580 & Mean dependent var & 0.000121 \\
S. E. of regression & 0.389800 & S. D. dependent var & 0.009742 \\
Sum squared resid & 0.007610 & Akaike info criterion & -6.896960 \\
Log likelihood & 0.005154 & Schwarz criterion & -6.841777 \\
F-statistic & 315.8117 & Hannan-Quinn criter. & -6.874697 \\
Prob (F-statistic) & 58.49253 & Durbin-Watson stat & 1.863979 \\
& &
\end{tabular}




\section{9) $\mathrm{CPI}$}

Null Hypothesis: D(L_CPI) has a unit root

Exogenous: Constant

Bandwidth: 0 (Newey-West automatic) using Bartlett kernel

\begin{tabular}{|c|c|c|c|}
\hline & & Adj. t-Stat & Prob.* \\
\hline Phillips-Perron test statistic & & -5.534652 & 0.0000 \\
\hline \multirow[t]{3}{*}{ Test critical values: } & $1 \%$ level & -3.503879 & \\
\hline & $5 \%$ level & -2.893589 & \\
\hline & $10 \%$ level & -2.583931 & \\
\hline
\end{tabular}

${ }^{*}$ MacKinnon (1996) one-sided p-values.

Residual variance (no correction)

$2.37 \mathrm{E}-05$

HAC corrected variance (Bartlett kernel)

$2.37 \mathrm{E}-05$

Phillips-Perron Test Equation

Dependent Variable: D(L_CPI,2)

Method: Least Squares

Date: $12 / 29 / 19 \quad$ Time: 10:48

Sample (adjusted): 2012M03 2019M09

Included observations: 91 after adjustments

\begin{tabular}{lcccc}
\hline \multicolumn{1}{c}{ Variable } & Coefficient & Std. Error & t-Statistic & Prob. \\
\hline \multicolumn{1}{c}{ D(L_CPI(-1)) } & -0.476819 & 0.086152 & -5.534652 & 0.0000 \\
\multicolumn{1}{c}{0.001902} & 0.000644 & 2.955474 & 0.0040 \\
R-squared & 0.256054 & Mean dependent var & -0.000227 \\
Adjusted R-squared & 0.247695 & S. D. dependent var & 0.005674 \\
S. E. of regression & 0.004922 & Akaike info criterion & -7.768622 \\
Sum squared resid & 0.002156 & Schwarz criterion & -7.713438 \\
Log likelihood & 355.4723 & Hannan-Quinn criter. & -7.746358 \\
F-statistic & 30.63237 & Durbin-Watson stat & 1.995626 \\
Prob (F-statistic) & 0.000000 & &
\end{tabular}




\section{0) Value of Mobile Phone Transactions}

Null Hypothesis: D(L_MOBVREV) has a unit root

Exogenous: Constant

Bandwidth: 2 (Newey-West automatic) using Bartlett kernel

\begin{tabular}{lccc}
\hline & & Adj. t-Stat & Prob. $^{*}$ \\
\hline Phillips-Perron test statistic & & -13.87363 & 0.0001 \\
\hline Test critical values: & $1 \%$ level & -3.503879 & \\
& $5 \%$ level & -2.893589 & \\
& $10 \%$ level & -2.583931 & \\
\hline
\end{tabular}

${ }^{*}$ MacKinnon (1996) one-sided p-values.

Residual variance (no correction)

0.007333

HAC corrected variance (Bartlett kernel)

0.006691

Phillips-Perron Test Equation

Dependent Variable: D(L_MOBVREV,2)

Method: Least Squares

Date: $12 / 29 / 19$ Time: 10:50

Sample (adjusted): 2012M03 2019M09

Included observations: 91 after adjustments

\begin{tabular}{lcccc}
\hline \multicolumn{1}{c}{ Variable } & Coefficient & Std. Error & t-Statistic & Prob. \\
\hline \multicolumn{1}{c}{ D(L_MOBVREV(-1)) } & -1.353954 & 0.099238 & -13.64352 & 0.0000 \\
& 0.031110 & 0.009355 & 3.325447 & 0.0013 \\
\hline R-squared & 0.676535 & Mean dependent var & 0.000215 \\
Adjusted R-squared & 0.672901 & S. D. dependent var & 0.151396 \\
S. E. of regression & 0.086587 & Akaike info criterion & -2.033595 \\
Sum squared resid & 0.667265 & Schwarz criterion & -1.978411 \\
Log likelihood & 94.52856 & Hannan-Quinn criter. & -2.011331 \\
F-statistic & 186.1457 & Durbin-Watson stat & 2.031075 \\
Prob (F-statistic) & 0.000000 & & \\
\hline
\end{tabular}




\section{1) Exchange Rate}

Null Hypothesis: D(L_NEERREV) has a unit root

Exogenous: Constant

Bandwidth: 4 (Newey-West automatic) using Bartlett kernel

\begin{tabular}{llll}
\hline & & Adj. t-Stat & Prob. ${ }^{*}$ \\
\hline Phillips-Perron test statistic & & -9.259917 & 0.0000 \\
\hline Test critical values: & $1 \%$ level & -3.503879 & \\
& 5\% level & -2.893589 & \\
& & & \\
& & -2.583931 \\
\hline
\end{tabular}

${ }^{\star}$ MacKinnon (1996) one-sided p-values.

Residual variance (no correction)

0.000655

HAC corrected variance (Bartlett kernel)

0.000748

Phillips-Perron Test Equation

Dependent Variable: D(L_NEERREV,2)

Method: Least Squares

Date: 12/29/19 Time: 11:00

Sample (adjusted): 2012M03 2019M09

Included observations: 91 after adjustments

\begin{tabular}{lcccc}
\hline \multicolumn{1}{c}{ Variable } & Coefficient & Std. Error & t-Statistic & Prob. \\
\hline D(L_NEERREV(-1)) & -0.989291 & 0.107425 & -9.209112 & 0.0000 \\
\multicolumn{1}{c}{-0.001076} & 0.002717 & -0.395904 & 0.6931 \\
\hline R-squared & 0.487940 & Mean dependent var & 0.000422 \\
Adjusted R-squared & 0.482186 & S. D. dependent var & 0.035953 \\
S. E. of regression & 0.025871 & Akaike info criterion & -4.449619 \\
Sum squared resid & 0.059571 & Schwarz criterion & -4.394436 \\
Log likelihood & 204.4577 & Hannan-Quinn criter. & -4.427356 \\
F-statistic & 84.80774 & Durbin-Watson stat & 1.974041 \\
Prob (F-statistic) & 0.000000 & & \\
\hline
\end{tabular}




\section{Appendix 1.3. Co-Integrating Relations}

\section{Appendix 1.3.1. Model with 1000 Notes as Dependent Variable}

Series: 1000 notes GDP (0fficial) GDP (Grey) Tbills rate CPI E/Rate Mobile

Lags interval: 1 to 2

Selected $\left(0.05\right.$ level $\left.^{\star}\right)$ Number of Cointegrating Relations by Model

\begin{tabular}{cccccc}
\hline Data Trend: & None & None & Linear & Linear & Quadratic \\
\hline Test Type & No Intercept & Intercept & Intercept & Intercept & Intercept \\
& No Trend & No Trend & No Trend & Trend & Trend \\
Trace & 3 & 3 & 2 & 3 & 2 \\
Max-Eig & 3 & 2 & 2 & 1 & 1 \\
& \multirow{2}{*}{ Critical values based on MacKinnon-Haug-Michelis (1999) }
\end{tabular}

\section{Appendix 1.3.2. Model with 2000 Notes as Dependent Variable}

Series: 2000 notes DGP (Official) GDP (Grey) Tbills rate CPI E/Rate Mobile

Lags interval: 1 to 2

Selected $\left(0.05\right.$ level$\left.^{\star}\right)$ Number of Cointegrating Relations by Model

\begin{tabular}{cccccc}
\hline Data Trend: & None & None & Linear & Linear & Quadratic \\
\hline Test Type & No Intercept & Intercept & Intercept & Intercept & Intercept \\
& No Trend & No Trend & No Trend & Trend & Trend \\
Trace & 4 & 4 & 2 & 2 & 2 \\
Max-Eig & 3 & 2 & 2 & 1 & 1 \\
${ }^{*}$ Critical values based on MacKinnon-Haug-Michelis (1999) & & \\
\hline
\end{tabular}

\section{Appendix 1.3.3. Model with 5000 Notes as Dependent Variable}

Series: 5,000 notes GDP (Official) GDP (Grey) Tbill rate CPI E/Rate Mobile

Lags interval: 1 to 4

Selected $\left(0.05\right.$ level $\left.^{\star}\right)$ Number of Cointegrating Relations by Model

\begin{tabular}{cccccc}
\hline Data Trend: & None & None & Linear & Linear & Quadratic \\
\hline Test Type & No Intercept & Intercept & Intercept & Intercept & Intercept \\
& No Trend & No Trend & No Trend & Trend & Trend \\
Trace & 5 & 4 & 3 & 3 & 4 \\
Max-Eig & 2 & 1 & 1 & 2 & 2
\end{tabular}

${ }^{*}$ Critical values based on MacKinnon-Haug-Michelis (1999) 
Appendix 1.3.4. Model with 10,000 Notes as Dependent Variable

Series: 10,000 notes GDP (Official) GDP (Grey) Tbills rate CPT E/Rate Mobile

Lags interval: 1 to 3

Selected $\left(0.05\right.$ level $\left.^{\star}\right)$ Number of Cointegrating Relations by Model

\begin{tabular}{cccccc}
\hline Data Trend: & None & None & Linear & Linear & Quadratic \\
\hline Test Type & No Intercept & Intercept & Intercept & Intercept & Intercept \\
& No Trend & No Trend & No Trend & Trend & Trend \\
Trace & 7 & 3 & 1 & 3 & 1 \\
Max-Eig & 2 & 2 & 1 & 1 & 1 \\
\hline \multirow{2}{*}{ Critical values based on MacKinnon-Haug-Michelis (1999) } \\
\hline
\end{tabular}

\section{Appendix 1.3.5. Model with Total Cash as Dependent Variable}

Series: all cash GDP (Official) GDP (Grey) Tbills rate CPI E/Rate Mobile

Lags interval: 1 to 2

Selected $\left(0.05\right.$ level $\left.^{*}\right)$ Number of Cointegrating Relations by Model

\begin{tabular}{cccccc}
\hline Data Trend: & None & None & Linear & Linear & Quadratic \\
\hline Test Type & No Intercept & Intercept & Intercept & Intercept & Intercept \\
& No Trend & No Trend & No Trend & Trend & Trend \\
Trace & 7 & 3 & 2 & 3 & 2 \\
Max-Eig & 2 & 2 & 1 & 1 & 1 \\
$*$ Critical values based on MacKinnon-Haug-Michelis (1999) & & \\
\hline
\end{tabular}




\section{Appendix 2. Vector Error Correction Estimates}

\section{Appendix 2.1. Demand for Cash: 1000 Notes Denomination}

Vector Error Correction Estimates

Date: $12 / 24 / 19$ Time: 09:00

Sample (adjusted): 2012M05 2019M09

Included observations: 89 after adjustments

Standard errors in ( ) \& t-statistics in [ ]

\begin{tabular}{|c|c|c|c|c|c|c|c|}
\hline Cointegrating Eq: & CointEq1 & & & & & & \\
\hline L_N1(-1) & 1.000000 & & & & & & \\
\hline L_RGDP15(-1) & $\begin{array}{c}-4.075214 \\
(1.62532) \\
{[-2.50732]}\end{array}$ & & & & & & \\
\hline R_3REV $(-1)$ & $\begin{array}{l}2.524685 \\
(2.62603) \\
{[0.96141]}\end{array}$ & & & & & & \\
\hline L_BLACKREV(-1) & $\begin{array}{c}-1.896839 \\
(0.89224) \\
{[-2.12593]}\end{array}$ & & & & & & \\
\hline L_MOBVREV(-1) & $\begin{array}{l}1.565916 \\
(0.26851) \\
{[5.83197]}\end{array}$ & & & & & & \\
\hline L_NEERREV(-1) & $\begin{array}{l}0.608786 \\
(0.61012) \\
{[0.99781]}\end{array}$ & & & & & & \\
\hline L_CPI(-1) & $\begin{array}{c}-7.460982 \\
(2.07218) \\
{[-3.60054]}\end{array}$ & & & & & & \\
\hline @TREND(12M01) & $\begin{array}{l}0.043732 \\
(0.01381) \\
{[3.16594]}\end{array}$ & & & & & & \\
\hline $\mathrm{C}$ & 62.55448 & & & & & & \\
\hline Error Correction: & $\mathrm{D}\left(\mathrm{L} \_\mathrm{N} 1\right)$ & D(L_RGDP15) & $\mathrm{D}\left(\mathrm{R} \_3 \mathrm{REV}\right)$ & $\mathrm{D}\left(\mathrm{L} \_\mathrm{BLACKRE}\right)$ & ) D(L_MOBVREV) & D(L_NEERREV) & $\mathrm{D}\left(\mathrm{L} \_\mathrm{CPI}\right)$ \\
\hline CointEq1 & $\begin{array}{c}-0.109879 \\
(0.05179) \\
{[-2.12162]}\end{array}$ & $\begin{array}{c}-0.047380 \\
(0.01126) \\
{[-4.20767]}\end{array}$ & $\begin{array}{c}-0.008218 \\
(0.00597) \\
{[-1.37657]}\end{array}$ & $\begin{array}{c}-0.037826 \\
(0.02534) \\
{[-1.49262]}\end{array}$ & $\begin{array}{c}-0.304640 \\
(0.06236) \\
{[-4.88531]}\end{array}$ & $\begin{array}{c}-0.008169 \\
(0.02000) \\
{[-0.40847]}\end{array}$ & $\begin{array}{c}-0.001792 \\
(0.00377) \\
{[-0.47534]}\end{array}$ \\
\hline $\mathrm{D}\left(\mathrm{L} \_\mathrm{N} 1(-1)\right)$ & $\begin{array}{l}0.021119 \\
(0.11537) \\
{[0.18305]}\end{array}$ & $\begin{array}{c}-0.121552 \\
(0.04657) \\
{[-2.61012]}\end{array}$ & $\begin{array}{l}0.006977 \\
(0.02469) \\
{[0.28258]}\end{array}$ & $\begin{array}{c}-0.081234 \\
(0.10481) \\
{[-0.77508]}\end{array}$ & $\begin{array}{l}0.478608 \\
(0.25789) \\
{[1.85583]}\end{array}$ & $\begin{array}{l}0.029658 \\
(0.08271) \\
{[0.35858]}\end{array}$ & $\begin{array}{c}-0.034482 \\
(0.01559) \\
{[-2.21142]}\end{array}$ \\
\hline
\end{tabular}




\begin{tabular}{|c|c|c|c|c|c|c|c|}
\hline \multirow{3}{*}{$\mathrm{D}\left(\mathrm{L} \_\mathrm{N} 1(-2)\right)$} & 0.012296 & -0.015066 & 0.031945 & -0.081947 & 0.471985 & 0.035980 & -0.018516 \\
\hline & $(0.12741)$ & $(0.05143)$ & $(0.02727)$ & $(0.11575)$ & $(0.28482)$ & $(0.09134)$ & $(0.01722)$ \\
\hline & {$[0.09651]$} & {$[-0.29294]$} & {$[1.17161]$} & {$[-0.70798]$} & {$[1.65714]$} & {$[0.39390]$} & {$[-1.07522]$} \\
\hline \multirow{3}{*}{$\mathrm{D}\left(\mathrm{L} \_\mathrm{N} 1(-3)\right)$} & 0.178266 & 0.048135 & -0.017292 & -0.039974 & 0.525482 & -0.088712 & 0.007074 \\
\hline & $(0.12889)$ & $(0.05203)$ & $(0.02758)$ & $(0.11709)$ & $(0.28811)$ & $(0.09240)$ & $(0.01742)$ \\
\hline & {$[1.38311]$} & {$[0.92521]$} & {$[-0.62695]$} & {$[-0.34140]$} & {$[1.82386]$} & {$[-0.96007]$} & {$[0.40608]$} \\
\hline \multirow{3}{*}{ D(L_RGDP15(-1)) } & -0.073775 & 0.441970 & 0.000507 & 0.765598 & 1.319188 & -0.049171 & 0.049467 \\
\hline & $(0.23822)$ & $(0.09616)$ & $(0.05098)$ & $(0.21641)$ & $(0.53252)$ & $(0.17078)$ & $(0.03220)$ \\
\hline & {$[-0.30969]$} & [4.59619] & {$[0.00995]$} & [3.53768] & {$[2.47725]$} & {$[-0.28791]$} & [1.53637] \\
\hline \multirow{3}{*}{ D(L_RGDP15(-2)) } & 0.392300 & -0.117397 & -0.019907 & 0.119834 & 0.109355 & -0.173235 & -0.051791 \\
\hline & $(0.26452)$ & $(0.10678)$ & $(0.05661)$ & $(0.24030)$ & $(0.59130)$ & $(0.18964)$ & $(0.03575)$ \\
\hline & [1.48307] & {$[-1.09948]$} & {$[-0.35167]$} & [0.49868] & [0.18494] & {$[-0.91351]$} & {$[-1.44863]$} \\
\hline \multirow{3}{*}{ D(L_RGDP15(-3)) } & -0.251421 & -0.570276 & -0.040878 & -1.111346 & 0.265490 & 0.067958 & 0.063858 \\
\hline & $(0.26162)$ & $(0.10561)$ & $(0.05599)$ & $(0.23767)$ & $(0.58483)$ & $(0.18756)$ & $(0.03536)$ \\
\hline & {$[-0.96101]$} & {$[-5.40008]$} & {$[-0.73015]$} & {$[-4.67603]$} & {$[0.45397]$} & {$[0.36233]$} & {$[1.80595]$} \\
\hline \multirow{3}{*}{$\mathrm{D}\left(\mathrm{R} \_3 \mathrm{REV}(-1)\right)$} & 0.149088 & -0.003868 & 0.163754 & 0.136007 & 0.755893 & -0.152705 & -0.024592 \\
\hline & $(0.55859)$ & $(0.22548)$ & $(0.11954)$ & $(0.50745)$ & $(1.24867)$ & $(0.40046)$ & $(0.07550)$ \\
\hline & {$[0.26690]$} & {$[-0.01715]$} & [1.36992] & {$[0.26802]$} & {$[0.60536]$} & {$[-0.38132]$} & {$[-0.32573]$} \\
\hline \multirow{3}{*}{$\mathrm{D}\left(\mathrm{R} \_3 \mathrm{REV}(-2)\right)$} & 0.762063 & 0.009664 & -0.179705 & -0.192784 & 0.621238 & -0.991840 & -0.041805 \\
\hline & $(0.52349)$ & $(0.21131)$ & $(0.11202)$ & $(0.47556)$ & $(1.17020)$ & $(0.37530)$ & $(0.07075)$ \\
\hline & {$[1.45574]$} & {$[0.04573]$} & {$[-1.60416]$} & {$[-0.40538]$} & {$[0.53088]$} & {$[-2.64282]$} & {$[-0.59085]$} \\
\hline \multirow{3}{*}{$\mathrm{D}\left(\mathrm{R} \_3 \mathrm{REV}(-3)\right)$} & 0.084435 & 0.187011 & -0.275632 & 0.220253 & 1.039262 & -0.443581 & 0.023261 \\
\hline & $(0.54864)$ & $(0.22146)$ & $(0.11741)$ & $(0.49841)$ & $(1.22642)$ & $(0.39333)$ & $(0.07415)$ \\
\hline & {$[0.15390]$} & {$[0.84444]$} & {$[-2.34769]$} & {$[0.44191]$} & {$[0.84739]$} & {$[-1.12777]$} & [0.31369] \\
\hline \multirow{3}{*}{$\mathrm{D}\left(\mathrm{L} \_\right.$BLACKREV $\left.(-1)\right)$} & -0.167431 & 0.123872 & 0.042590 & -0.191781 & -1.277951 & 0.072498 & 0.001550 \\
\hline & $(0.16316)$ & $(0.06586)$ & $(0.03492)$ & $(0.14823)$ & $(0.36474)$ & $(0.11697)$ & $(0.02205)$ \\
\hline & {$[-1.02615]$} & [1.88076] & {$[1.21976]$} & {$[-1.29384]$} & {$[-3.50377]$} & {$[0.61977]$} & {$[0.07027]$} \\
\hline \multirow{3}{*}{$\mathrm{D}\left(\mathrm{L} \_\right.$BLACKREV $\left.(-2)\right)$} & -0.186308 & 0.084470 & 0.060185 & -0.083658 & -1.205228 & 0.203744 & 0.015344 \\
\hline & $(0.16669)$ & $(0.06729)$ & $(0.03567)$ & $(0.15143)$ & $(0.37262)$ & $(0.11950)$ & $(0.02253)$ \\
\hline & {$[-1.11769]$} & [1.25540] & [1.68723] & {$[-0.55245]$} & {$[-3.23449]$} & [1.70493] & {$[0.68108]$} \\
\hline \multirow{3}{*}{ D(L_BLACKREV $(-3))$} & -0.194768 & 0.025883 & 0.064868 & 0.728505 & -1.073319 & 0.053563 & 0.014890 \\
\hline & $(0.17418)$ & $(0.07031)$ & $(0.03727)$ & $(0.15823)$ & $(0.38936)$ & $(0.12487)$ & $(0.02354)$ \\
\hline & {$[-1.11819]$} & {$[0.36813]$} & {$[1.74031]$} & [4.60397] & {$[-2.75661]$} & {$[0.42895]$} & {$[0.63251]$} \\
\hline \multirow{3}{*}{ D(L_MOBVREV $(-1))$} & -0.069136 & -0.029174 & -0.001142 & -0.039866 & -0.325636 & -0.024877 & 0.007279 \\
\hline & $(0.04890)$ & $(0.01974)$ & $(0.01047)$ & $(0.04443)$ & $(0.10932)$ & $(0.03506)$ & $(0.00661)$ \\
\hline & {$[-1.41372]$} & {$[-1.47789]$} & {$[-0.10914]$} & {$[-0.89736]$} & {$[-2.97878]$} & {$[-0.70955]$} & [1.10128] \\
\hline \multirow{3}{*}{ D(L_MOBVREV $(-2))$} & 0.020624 & -0.004422 & -0.008152 & -0.016188 & -0.129013 & -0.084491 & 0.000395 \\
\hline & $(0.05024)$ & $(0.02028)$ & $(0.01075)$ & $(0.04564)$ & $(0.11230)$ & $(0.03602)$ & $(0.00679)$ \\
\hline & {$[0.41052]$} & {$[-0.21808]$} & {$[-0.75825]$} & {$[-0.35470]$} & {$[-1.14879]$} & {$[-2.34588]$} & {$[0.05824]$} \\
\hline \multirow{3}{*}{$\mathrm{D}\left(\mathrm{L} \_\mathrm{MOBVREV}(-3)\right)$} & 0.010293 & 0.025833 & 0.004681 & 0.036954 & 0.086337 & -0.051001 & 0.009041 \\
\hline & $(0.04790)$ & $(0.01933)$ & $(0.01025)$ & $(0.04351)$ & $(0.10707)$ & $(0.03434)$ & $(0.00647)$ \\
\hline & {$[0.21489]$} & {$[1.33606]$} & {$[0.45666]$} & {$[0.84924]$} & {$[0.80633]$} & {$[-1.48519]$} & [1.39656] \\
\hline
\end{tabular}




\section{Continued}

\begin{tabular}{|c|c|c|c|c|c|c|c|}
\hline \multirow{3}{*}{ D(L_NEERREV(-1)) } & 0.099340 & -0.066330 & -0.038520 & -0.037082 & 0.824023 & -0.139548 & -0.033521 \\
\hline & $(0.16351)$ & $(0.06600)$ & $(0.03499)$ & $(0.14854)$ & $(0.36551)$ & $(0.11722)$ & $(0.02210)$ \\
\hline & {$[0.60755]$} & {$[-1.00498]$} & {$[-1.10087]$} & {$[-0.24964]$} & {$[2.25446]$} & {$[-1.19046]$} & {$[-1.51681]$} \\
\hline \multirow{3}{*}{ D(L_NEERREV(-2)) } & 0.113097 & -0.070758 & -0.075589 & -0.185058 & 0.356328 & -0.065580 & 0.003800 \\
\hline & $(0.15936)$ & $(0.06433)$ & $(0.03410)$ & $(0.14477)$ & $(0.35623)$ & $(0.11425)$ & $(0.02154)$ \\
\hline & [0.70969] & [-1.09997] & {$[-2.21655]$} & {$[-1.27829]$} & [1.00027] & {$[-0.57402]$} & {$[0.17641]$} \\
\hline \multirow{3}{*}{ D(L_NEERREV $(-3))$} & 0.093127 & -0.136081 & 0.018155 & -0.187231 & 0.204328 & 0.185802 & 0.011469 \\
\hline & $(0.15809)$ & $(0.06381)$ & $(0.03383)$ & $(0.14362)$ & $(0.35339)$ & $(0.11334)$ & $(0.02137)$ \\
\hline & {$[0.58908]$} & {$[-2.13246]$} & {$[0.53664]$} & {$[-1.30368]$} & [0.57819] & [1.63938] & {$[0.53675]$} \\
\hline \multirow{3}{*}{$\mathrm{D}\left(\mathrm{L} \_\mathrm{CPI}(-1)\right)$} & -0.045631 & 1.740447 & -0.330772 & 1.639912 & -2.128323 & -0.216329 & 0.494346 \\
\hline & $(0.79756)$ & $(0.32194)$ & $(0.17067)$ & $(0.72454)$ & $(1.78285)$ & $(0.57178)$ & $(0.10779)$ \\
\hline & {$[-0.05721]$} & {$[5.40615]$} & {$[-1.93805]$} & {$[2.26340]$} & {$[-1.19378]$} & {$[-0.37835]$} & {$[4.58600]$} \\
\hline \multirow{3}{*}{$\mathrm{D}\left(\mathrm{L} \_\mathrm{CPI}(-2)\right)$} & -1.561178 & 0.074646 & 0.246966 & 0.121429 & -4.638020 & 0.695396 & 0.143542 \\
\hline & $(1.00877)$ & $(0.40720)$ & $(0.21587)$ & $(0.91642)$ & $(2.25500)$ & $(0.72320)$ & $(0.13634)$ \\
\hline & {$[-1.54760]$} & {$[0.18332]$} & [1.14404] & {$[0.13250]$} & {$[-2.05677]$} & {$[0.96155]$} & {$[1.05281]$} \\
\hline \multirow{3}{*}{$\mathrm{D}\left(\mathrm{L} \_\mathrm{CPI}(-3)\right)$} & 1.110069 & -0.674819 & 0.109248 & -1.445569 & -4.176435 & -0.075003 & -0.159598 \\
\hline & (1.06317) & $(0.42916)$ & $(0.22751)$ & $(0.96584)$ & $(2.37661)$ & $(0.76220)$ & $(0.14369)$ \\
\hline & [1.04411] & {$[-1.57243]$} & {$[0.48018]$} & {$[-1.49670]$} & {$[-1.75731]$} & {$[-0.09840]$} & {$[-1.11067]$} \\
\hline \multirow{3}{*}{$\mathrm{C}$} & 0.015525 & -0.001229 & -0.003430 & 0.008919 & 0.105760 & -0.003329 & 0.001373 \\
\hline & $(0.00982)$ & $(0.00396)$ & $(0.00210)$ & $(0.00892)$ & $(0.02194)$ & $(0.00704)$ & $(0.00133)$ \\
\hline & {$[1.58163]$} & {$[-0.31007]$} & {$[-1.63274]$} & {$[1.00024]$} & [4.81996] & {$[-0.47310]$} & {$[1.03481]$} \\
\hline R-squared & 0.678107 & 0.900547 & 0.345735 & 0.714023 & 0.490074 & 0.325025 & 0.544233 \\
\hline Adj. R-squared & 0.537476 & 0.867396 & 0.127647 & 0.618697 & 0.320098 & 0.100034 & 0.392311 \\
\hline Sum sq. resids & 0.074787 & 0.012186 & 0.003425 & 0.061720 & 0.373707 & 0.038438 & 0.001366 \\
\hline S.E. equation & 0.033662 & 0.013588 & 0.007204 & 0.030580 & 0.075248 & 0.024133 & 0.004550 \\
\hline F-statistic & 1.155740 & 27.16503 & 1.585301 & 7.490353 & 2.883204 & 1.444612 & 3.582311 \\
\hline Log likelihood & 188.8523 & 269.5923 & 326.0729 & 197.3980 & 117.2594 & 218.4718 & 366.9701 \\
\hline Akaike AIC & -3.727018 & -5.541399 & -6.810626 & -3.919057 & -2.118189 & -4.392625 & -7.729666 \\
\hline Schwarz SC & -3.083887 & -4.898268 & -6.167495 & -3.275926 & -1.475058 & -3.749494 & -7.086535 \\
\hline Mean dependent & 0.006814 & 0.004269 & -0.001041 & 0.012095 & 0.021105 & -0.000531 & 0.004127 \\
\hline S. D. dependent & 0.034311 & 0.037314 & 0.007713 & 0.049523 & 0.091258 & 0.025439 & 0.005836 \\
\hline \multicolumn{2}{|c|}{ Determinant resid covariance (dof adj.) } & $3.62 \mathrm{E}-25$ & & & & & \\
\hline \multicolumn{2}{|c|}{ Determinant resid covariance } & $4.46 \mathrm{E}-26$ & & & & & \\
\hline \multicolumn{2}{|c|}{ Log likelihood } & 1713.527 & & & & & \\
\hline \multicolumn{2}{|c|}{ Akaike information criterion } & -34.70848 & & & & & \\
\hline \multicolumn{2}{|c|}{ Schwarz criterion } & -29.98286 & & & & & \\
\hline \multicolumn{2}{|c|}{ Number of coefficients } & 169 & & & & & \\
\hline
\end{tabular}




\section{Appendix 2.2. Demand for Cash: 2000 Notes Denomination}

Vector Error Correction Estimates

Date: 12/24/19 Time: 15:59

Sample (adjusted): 2012M06 2019M09

Included observations: 88 after adjustments

Standard errors in ( ) \& t-statistics in [ ]

\begin{tabular}{|c|c|c|c|c|c|c|c|}
\hline Cointegrating Eq: & CointEq1 & & & & & & \\
\hline \multirow[t]{2}{*}{ L_N2(-1) } & 1.000000 & & & & & & \\
\hline & -1.679107 & & & & & & \\
\hline \multirow[t]{3}{*}{ L_RGDP15(-1) } & $(0.81512)$ & & & & & & \\
\hline & {$[-2.05996]$} & & & & & & \\
\hline & -2.710499 & & & & & & \\
\hline \multirow[t]{3}{*}{ R_3REV $(-1)$} & $(2.05181)$ & & & & & & \\
\hline & {$[-1.32103]$} & & & & & & \\
\hline & -2.750164 & & & & & & \\
\hline \multirow[t]{3}{*}{ L_BLACKREV $(-1)$} & $(0.62099)$ & & & & & & \\
\hline & {$[-4.42865]$} & & & & & & \\
\hline & 0.427459 & & & & & & \\
\hline \multirow[t]{3}{*}{ L_MOBVREV $(-1)$} & $(0.22477)$ & & & & & & \\
\hline & [1.90600] & & & & & & \\
\hline & 0.740581 & & & & & & \\
\hline \multirow[t]{3}{*}{ L_NEERREV $(-1)$} & $(0.70464)$ & & & & & & \\
\hline & {$[1.05100]$} & & & & & & \\
\hline & -5.537725 & & & & & & \\
\hline \multirow[t]{2}{*}{ L_CPI $(-1)$} & $(1.70496)$ & & & & & & \\
\hline & {$[-3.24801]$} & & & & & & \\
\hline \multirow[t]{2}{*}{ Error Correction: } & $\mathrm{D}\left(\mathrm{L} \_\mathrm{N} 2\right)$ & D(L_RGDP15) & $\mathrm{D}\left(\mathrm{R} \_3 \mathrm{REV}\right)$ & D(L_BLACKREV & D(L_MOBVREV) & D(L_NEERREV) & $\mathrm{D}\left(\mathrm{L} \_\mathrm{CPI}\right)$ \\
\hline & -0.063725 & -0.043956 & -0.000158 & -0.015076 & -0.173924 & -0.017907 & -0.020196 \\
\hline \multirow[t]{3}{*}{ CointEq1 } & $(0.03442)$ & $(0.00767)$ & $(0.00573)$ & $(0.00387)$ & $(0.07012)$ & $(0.01997)$ & $(0.00366)$ \\
\hline & {$[-1.85129]$} & {$[-5.72893]$} & {$[-0.02764]$} & {$[-3.89560]$} & {$[-2.48029]$} & {$[-0.89689]$} & {$[-5.51803]$} \\
\hline & 0.153215 & -0.000443 & -0.007882 & 0.043256 & 0.088734 & -0.007603 & 0.008077 \\
\hline \multirow[t]{2}{*}{$\mathrm{D}\left(\mathrm{L} \_\mathrm{N} 2(-1)\right)$} & $(0.12599)$ & $(0.02808)$ & $(0.02099)$ & $(0.08738)$ & $(0.25665)$ & $(0.07307)$ & $(0.01339)$ \\
\hline & {$[1.21612]$} & {$[-0.01576]$} & {$[-0.37559]$} & {$[0.49504]$} & {$[0.34573]$} & {$[-0.10404]$} & {$[0.60324]$} \\
\hline
\end{tabular}




\section{Continued}

\begin{tabular}{|c|c|c|c|c|c|c|c|}
\hline \multirow{3}{*}{$\mathrm{D}\left(\mathrm{L} \_\mathrm{N} 2(-2)\right)$} & 0.209578 & -0.001601 & -0.040688 & 0.144927 & -0.124182 & -0.036413 & -0.007437 \\
\hline & $(0.11251)$ & $(0.02508)$ & $(0.01874)$ & $(0.07804)$ & $(0.22921)$ & $(0.06526)$ & $(0.01196)$ \\
\hline & {$[1.86267]$} & {$[-0.06384]$} & {$[-2.17090]$} & {$[1.85721]$} & {$[-0.54179]$} & {$[-0.55796]$} & {$[-0.62200]$} \\
\hline \multirow{3}{*}{$\mathrm{D}\left(\mathrm{L} \_\mathrm{N} 2(-3)\right)$} & 0.034855 & 0.024179 & -0.002553 & 0.186546 & 0.105884 & 0.004588 & -0.001767 \\
\hline & $(0.11703)$ & $(0.02609)$ & $(0.01950)$ & $(0.08117)$ & $(0.23841)$ & $(0.06788)$ & $(0.01244)$ \\
\hline & {$[0.29782]$} & [0.92687] & {$[-0.13096]$} & [2.29826] & {$[0.44412]$} & [0.06759] & {$[-0.14208]$} \\
\hline \multirow{3}{*}{$\mathrm{D}\left(\mathrm{L} \_\mathrm{N} 2(-4)\right)$} & -0.193823 & -0.027459 & -0.006677 & 0.031935 & -0.135203 & 0.090880 & 0.012244 \\
\hline & $(0.10974)$ & $(0.02446)$ & $(0.01828)$ & $(0.07611)$ & $(0.22355)$ & $(0.06365)$ & $(0.01166)$ \\
\hline & {$[-1.76628]$} & {$[-1.12259]$} & {$[-0.36529]$} & {$[0.41960]$} & {$[-0.60481]$} & {$[1.42784]$} & [1.04991] \\
\hline \multirow{3}{*}{$\mathrm{D}\left(\mathrm{L} \_\right.$RGDP15(-1)) } & -0.423537 & 0.823406 & -0.016494 & 1.349390 & 0.182093 & -0.284216 & 0.130497 \\
\hline & $(0.44027)$ & $(0.09814)$ & $(0.07334)$ & $(0.30535)$ & $(0.89689)$ & $(0.25536)$ & $(0.04679)$ \\
\hline & {$[-0.96199]$} & [8.39038] & {$[-0.22490]$} & {$[4.41914]$} & {$[0.20303]$} & {$[-1.11298]$} & [2.78910] \\
\hline \multirow{3}{*}{ D(L_RGDP15(-2)) } & 0.554051 & -0.044746 & -0.019364 & 0.441522 & -0.256266 & -0.052205 & -0.034352 \\
\hline & $(0.35874)$ & $(0.07996)$ & $(0.05976)$ & $(0.24881)$ & $(0.73080)$ & $(0.20807)$ & $(0.03812)$ \\
\hline & {$[1.54444]$} & {$[-0.55958]$} & {$[-0.32403]$} & [1.77457] & {$[-0.35066]$} & {$[-0.25089]$} & {$[-0.90108]$} \\
\hline \multirow{3}{*}{ D(L_RGDP15(-3)) } & -0.823504 & -0.946966 & -0.090731 & -1.185510 & -0.297330 & 0.194552 & 0.008180 \\
\hline & $(0.38697)$ & $(0.08626)$ & $(0.06446)$ & $(0.26838)$ & $(0.78831)$ & $(0.22445)$ & $(0.04112)$ \\
\hline & {$[-2.12809]$} & {$[-10.9786]$} & {$[-1.40755]$} & {$[-4.41723]$} & {$[-0.37718]$} & {$[0.86680]$} & [0.19891] \\
\hline \multirow{3}{*}{$\mathrm{D}\left(\mathrm{L} \_\right.$RGDP15(-4)) } & -0.521449 & 0.742666 & -0.064929 & 1.308453 & -1.170118 & 0.158242 & 0.093723 \\
\hline & $(0.51652)$ & $(0.11513)$ & $(0.08604)$ & $(0.35823)$ & $(1.05222)$ & $(0.29959)$ & $(0.05489)$ \\
\hline & {$[-1.00955]$} & {$[6.45053]$} & {$[-0.75463]$} & {$[3.65251]$} & {$[-1.11205]$} & {$[0.52820]$} & {$[1.70745]$} \\
\hline \multirow{3}{*}{$\mathrm{D}\left(\mathrm{R} \_3 \operatorname{REV}(-1)\right)$} & 0.312269 & 0.400278 & 0.064791 & 0.906010 & -0.220634 & -0.014804 & 0.000375 \\
\hline & $(0.76497)$ & $(0.17051)$ & $(0.12743)$ & $(0.53055)$ & $(1.55836)$ & $(0.44370)$ & $(0.08129)$ \\
\hline & {$[0.40821]$} & [2.34749] & {$[0.50845]$} & {$[1.70768]$} & {$[-0.14158]$} & {$[-0.03336]$} & [0.00462] \\
\hline \multirow{3}{*}{$\mathrm{D}\left(\mathrm{R} \_3 \operatorname{REV}(-2)\right)$} & -0.850373 & -0.067192 & -0.202657 & -0.297900 & -0.268130 & -0.848499 & -0.054436 \\
\hline & $(0.75931)$ & $(0.16925)$ & $(0.12649)$ & $(0.52663)$ & $(1.54683)$ & $(0.44041)$ & $(0.08069)$ \\
\hline & [-1.11992] & {$[-0.39700]$} & {$[-1.60222]$} & {$[-0.56568]$} & {$[-0.17334]$} & {$[-1.92659]$} & {$[-0.67461]$} \\
\hline \multirow{3}{*}{$\mathrm{D}\left(\mathrm{R} \_3 \mathrm{REV}(-3)\right)$} & -1.021949 & 0.175575 & -0.236259 & 0.220081 & 1.486185 & -0.137272 & -0.028278 \\
\hline & $(0.72182)$ & $(0.16089)$ & $(0.12024)$ & $(0.50062)$ & $(1.47044)$ & $(0.41867)$ & $(0.07671)$ \\
\hline & {$[-1.41580]$} & [1.09125] & {$[-1.96491]$} & {$[0.43962]$} & {$[1.01071]$} & {$[-0.32788]$} & {$[-0.36864]$} \\
\hline \multirow{3}{*}{$\mathrm{D}\left(\mathrm{R} \_3 \operatorname{REV}(-4)\right)$} & -0.256456 & -0.043670 & -0.161048 & 0.076312 & -1.113319 & -0.166605 & 0.002174 \\
\hline & $(0.74565)$ & $(0.16621)$ & $(0.12421)$ & $(0.51715)$ & $(1.51900)$ & $(0.43249)$ & $(0.07924)$ \\
\hline & {$[-0.34394]$} & {$[-0.26275]$} & {$[-1.29658]$} & {$[0.14756]$} & {$[-0.73293]$} & {$[-0.38522]$} & {$[0.02743]$} \\
\hline
\end{tabular}




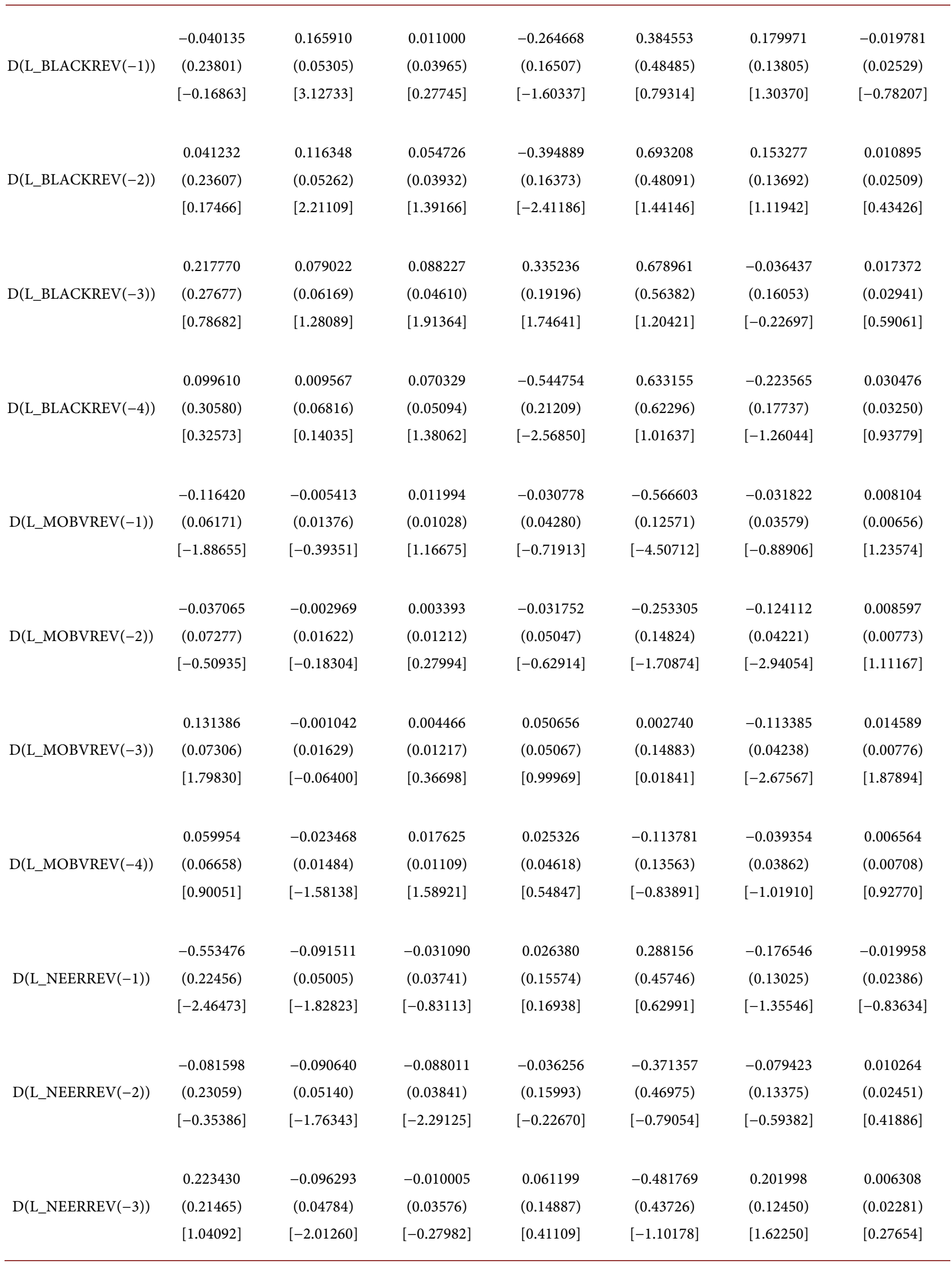




\section{Continued}

\begin{tabular}{|c|c|c|c|c|c|c|c|}
\hline \multirow{3}{*}{$\mathrm{D}\left(\mathrm{L} \_\right.$NEERREV $\left.(-4)\right)$} & -0.405305 & 0.031285 & 0.055210 & 0.102758 & -0.391068 & -0.055533 & -0.011803 \\
\hline & $(0.21304)$ & $(0.04749)$ & $(0.03549)$ & $(0.14776)$ & $(0.43399)$ & $(0.12357)$ & $(0.02264)$ \\
\hline & [-1.90247] & {$[0.65881]$} & [1.55575] & [0.69546] & {$[-0.90109]$} & {$[-0.44941]$} & {$[-0.52131]$} \\
\hline \multirow{3}{*}{$\mathrm{D}\left(\mathrm{L} \_\mathrm{CPI}(-1)\right)$} & -0.300197 & 0.225745 & -0.597127 & 1.386657 & 0.321719 & -0.111059 & 0.241346 \\
\hline & (1.16128) & $(0.25885)$ & $(0.19344)$ & $(0.80541)$ & $(2.36568)$ & $(0.67356)$ & $(0.12341)$ \\
\hline & {$[-0.25851]$} & {$[0.87211]$} & {$[-3.08683]$} & {$[1.72168]$} & [0.13599] & {$[-0.16488]$} & [1.95564] \\
\hline \multirow{3}{*}{$\mathrm{D}\left(\mathrm{L} \_\mathrm{CPI}(-2)\right)$} & -1.844837 & -0.453743 & 0.173724 & 0.041062 & -0.752838 & 1.005123 & 0.151863 \\
\hline & $(1.24616)$ & $(0.27777)$ & $(0.20758)$ & $(0.86428)$ & $(2.53860)$ & $(0.72279)$ & $(0.13243)$ \\
\hline & {$[-1.48042]$} & {$[-1.63351]$} & [0.83689] & {$[0.04751]$} & {$[-0.29656]$} & [1.39061] & [1.14673] \\
\hline \multirow{3}{*}{$\mathrm{D}\left(\mathrm{L} \_\mathrm{CPI}(-3)\right)$} & 2.991834 & -0.646629 & -0.167865 & -1.407414 & 0.929031 & -0.448368 & -0.067623 \\
\hline & $(1.20407)$ & $(0.26839)$ & $(0.20057)$ & $(0.83509)$ & $(2.45285)$ & $(0.69838)$ & $(0.12796)$ \\
\hline & [2.48477] & {$[-2.40931]$} & {$[-0.83693]$} & {$[-1.68535]$} & {$[0.37876]$} & {$[-0.64201]$} & {$[-0.52848]$} \\
\hline \multirow{3}{*}{$\mathrm{D}\left(\mathrm{L} \_\mathrm{CPI}(-4)\right)$} & 0.558861 & -0.252033 & -0.221770 & 1.835034 & 0.941932 & 0.155231 & 0.034254 \\
\hline & $(1.25027)$ & $(0.27869)$ & $(0.20827)$ & $(0.86713)$ & $(2.54697)$ & $(0.72518)$ & $(0.13287)$ \\
\hline & [0.44699] & {$[-0.90436]$} & {$[-1.06483]$} & [2.11621] & {$[0.36982]$} & {$[0.21406]$} & {$[0.25781]$} \\
\hline R-squared & 0.624694 & 0.958376 & 0.457062 & 0.771365 & 0.413120 & 0.395095 & 0.614179 \\
\hline Adj. R-squared & 0.446583 & 0.938623 & 0.199396 & 0.662860 & 0.134601 & 0.108021 & 0.431077 \\
\hline Sum sq. resids & 0.102394 & 0.005087 & 0.002841 & 0.049253 & 0.424926 & 0.034447 & 0.001156 \\
\hline S. E. equation & 0.041659 & 0.009286 & 0.006940 & 0.028893 & 0.084865 & 0.024163 & 0.004427 \\
\hline F-statistic & 3.507325 & 48.51673 & 1.773856 & 7.109036 & 1.483273 & 1.376282 & 3.354302 \\
\hline Log likelihood & 172.4092 & 304.4995 & 330.1307 & 204.6106 & 109.7932 & 220.3426 & 369.6841 \\
\hline Akaike AIC & -3.259299 & -6.261352 & -6.843880 & -3.991151 & -1.836209 & -4.348696 & -7.742821 \\
\hline Schwarz SC & -2.442904 & -5.444957 & -6.027485 & -3.174756 & -1.019814 & -3.532301 & -6.926426 \\
\hline Mean dependent & 0.010037 & 0.004466 & -0.001055 & 0.012320 & 0.020044 & -0.000537 & 0.004133 \\
\hline S. D. dependent & 0.056000 & 0.037482 & 0.007756 & 0.049761 & 0.091227 & 0.025584 & 0.005869 \\
\hline \multicolumn{2}{|c|}{ Determinant resid covariance (dof adj.) } & $2.70 \mathrm{E}-25$ & & & & & \\
\hline \multicolumn{2}{|c|}{ Determinant resid covariance } & $1.65 \mathrm{E}-26$ & & & & & \\
\hline \multicolumn{2}{|l|}{ Log likelihood } & 1738.171 & & & & & \\
\hline \multicolumn{2}{|c|}{ Akaike information criterion } & -34.73117 & & & & & \\
\hline \multicolumn{2}{|l|}{ Schwarz criterion } & -28.81934 & & & & & \\
\hline \multicolumn{2}{|l|}{ Number of coefficients } & 210 & & & & & \\
\hline
\end{tabular}




\section{Appendix 2.3. Demand for Cash: 5000 Notes Denomination}

Vector Error Correction Estimates

Date: $12 / 28 / 19$ Time: 08:49

Sample (adjusted): 2012M05 2019M09

Included observations: 89 after adjustments

Standard errors in ( ) \& t-statistics in [ ]

\begin{tabular}{|c|c|c|c|c|c|c|c|}
\hline Cointegrating Eq: & CointEq1 & & & & & & \\
\hline L_N5(-1) & 1.000000 & & & & & & \\
\hline L_RGDP15(-1) & $\begin{array}{c}-0.928992 \\
(0.41385) \\
{[-2.24475]}\end{array}$ & & & & & & \\
\hline R_3REV $(-1)$ & $\begin{array}{l}2.081407 \\
(0.94942) \\
{[2.19229]}\end{array}$ & & & & & & \\
\hline L_BLACKREV(-1) & $\begin{array}{c}-0.120738 \\
(0.06460) \\
{[-1.86900]}\end{array}$ & & & & & & \\
\hline L_MOBVREV(-1) & $\begin{array}{l}0.074653 \\
(0.02212) \\
{[3.37490]}\end{array}$ & & & & & & \\
\hline L_NEERREV(-1) & $\begin{array}{l}-0.613001 \\
(0.35186) \\
{[-1.74217]}\end{array}$ & & & & & & \\
\hline L_CPI $(-1)$ & $\begin{array}{l}-0.130652 \\
(0.03701) \\
{[-3.53018]}\end{array}$ & & & & & & \\
\hline @TREND(12M01) & $\begin{array}{l}0.026627 \\
(0.00714) \\
{[3.72730]}\end{array}$ & & & & & & \\
\hline $\mathrm{C}$ & 1.276332 & & & & & & \\
\hline Error Correction: & D(L_N5) & D(L_RGDP15) & $\mathrm{D}$ (R_3REV) & D(L_BLACKREV) & D(L_MOBVREV) & D(L_NEERREV) & $\mathrm{D}\left(\mathrm{L} \_\mathrm{CPI}\right)$ \\
\hline CointEq1 & $\begin{array}{c}-0.223119 \\
(0.06482) \\
{[-3.44233]}\end{array}$ & $\begin{array}{c}-0.092353 \\
(0.02055) \\
{[4.49331]}\end{array}$ & $\begin{array}{l}-0.024056 \\
(0.01197) \\
{[2.00958]}\end{array}$ & $\begin{array}{l}0.094927 \\
(0.05123) \\
{[1.85293]}\end{array}$ & $\begin{array}{c}-0.209170 \\
(0.14180) \\
{[1.47508]}\end{array}$ & $\begin{array}{c}-0.058430 \\
(0.04125) \\
{[-1.41639]}\end{array}$ & $\begin{array}{c}-0.024434 \\
(0.00739) \\
{[3.30667]}\end{array}$ \\
\hline $\mathrm{D}\left(\mathrm{L} \_\mathrm{N} 5(-1)\right)$ & $\begin{array}{l}0.330899 \\
(0.08843) \\
{[3.74204]}\end{array}$ & $\begin{array}{c}-0.177826 \\
(0.02804) \\
{[-6.34171]}\end{array}$ & $\begin{array}{l}0.003366 \\
(0.01633) \\
{[0.20611]}\end{array}$ & $\begin{array}{c}-0.153002 \\
(0.06989) \\
{[-2.18909]}\end{array}$ & $\begin{array}{l}0.522664 \\
(0.19346) \\
{[2.70169]}\end{array}$ & $\begin{array}{l}0.038704 \\
(0.05628) \\
{[0.68771]}\end{array}$ & $\begin{array}{c}-0.025553 \\
(0.01008) \\
{[-2.53477]}\end{array}$ \\
\hline
\end{tabular}




\section{Continued}

\begin{tabular}{|c|c|c|c|c|c|c|c|}
\hline \multirow{3}{*}{ D(L_N5(-2)) } & 0.009548 & -0.051348 & 0.029844 & -0.071426 & -0.283061 & -0.028367 & -0.025510 \\
\hline & $(0.12156)$ & $(0.03855)$ & $(0.02245)$ & $(0.09608)$ & $(0.26593)$ & $(0.07736)$ & $(0.01386)$ \\
\hline & {$[0.07855]$} & {$[-1.33213]$} & {$[1.32936]$} & {$[-0.74342]$} & {$[-1.06440]$} & {$[-0.36667]$} & [-1.84084] \\
\hline \multirow{3}{*}{ D(L_N5(-3)) } & 0.365538 & 0.006711 & -0.029972 & -0.042892 & -0.053606 & 0.046768 & -0.028054 \\
\hline & $(0.11882)$ & $(0.03768)$ & $(0.02194)$ & $(0.09392)$ & $(0.25995)$ & $(0.07562)$ & $(0.01355)$ \\
\hline & {$[3.07636]$} & {$[0.17811]$} & {$[-1.36578]$} & {$[-0.45670]$} & {$[-0.20621]$} & {$[0.61842]$} & {$[-2.07106]$} \\
\hline \multirow{3}{*}{ D(L_RGDP15(-1)) } & -0.717545 & 0.427410 & 0.059043 & 0.718733 & 0.373579 & -0.117202 & 0.027629 \\
\hline & $(0.31426)$ & $(0.09965)$ & $(0.05804)$ & $(0.24839)$ & $(0.68753)$ & $(0.20001)$ & $(0.03583)$ \\
\hline & {$[-2.28328]$} & [4.28897] & {$[1.01728]$} & {$[2.89354]$} & {$[0.54337]$} & {$[-0.58598]$} & {$[0.77120]$} \\
\hline \multirow{3}{*}{ D(L_RGDP15(-2)) } & 1.366425 & 0.078562 & -0.037530 & 0.282172 & 0.482516 & -0.145450 & -0.037560 \\
\hline & $(0.34693)$ & $(0.11001)$ & $(0.06407)$ & $(0.27421)$ & $(0.75899)$ & $(0.22080)$ & $(0.03955)$ \\
\hline & [3.93866] & {$[0.71413]$} & {$[-0.58573]$} & [1.02903] & {$[0.63573]$} & {$[-0.65874]$} & {$[-0.94967]$} \\
\hline \multirow{3}{*}{ D(L_RGDP15(-3)) } & -1.483815 & -0.478921 & -0.014426 & -1.049923 & -0.393454 & 0.004666 & 0.078994 \\
\hline & $(0.30101)$ & $(0.09545)$ & $(0.05559)$ & $(0.23792)$ & $(0.65853)$ & $(0.19158)$ & $(0.03432)$ \\
\hline & {$[-4.92949]$} & {$[-5.01749]$} & {$[-0.25950]$} & {$[-4.41299]$} & {$[-0.59747]$} & {$[0.02436]$} & [2.30199] \\
\hline \multirow{3}{*}{$\mathrm{D}\left(\mathrm{R} \_3 \operatorname{REV}(-1)\right)$} & -1.415368 & 0.266706 & 0.182034 & 0.356580 & -0.276570 & -0.142841 & 0.052805 \\
\hline & $(0.62817)$ & $(0.19920)$ & $(0.11602)$ & $(0.49651)$ & $(1.37429)$ & $(0.39980)$ & $(0.07161)$ \\
\hline & {$[-2.25315]$} & [1.33891] & [1.56904] & {$[0.71817]$} & {$[-0.20125]$} & {$[-0.35728]$} & {$[0.73736]$} \\
\hline \multirow{3}{*}{$\mathrm{D}\left(\mathrm{R} \_3 \operatorname{REV}(-2)\right)$} & -0.401894 & -0.110993 & -0.141498 & -0.169733 & 1.069817 & -1.065265 & -0.028311 \\
\hline & $(0.58023)$ & $(0.18399)$ & $(0.10716)$ & $(0.45861)$ & $(1.26939)$ & $(0.36928)$ & $(0.06615)$ \\
\hline & {$[-0.69265]$} & {$[-0.60325]$} & {$[-1.32042]$} & {$[-0.37010]$} & {$[0.84278]$} & {$[-2.88468]$} & {$[-0.42801]$} \\
\hline \multirow{3}{*}{$\mathrm{D}\left(\mathrm{R} \_3 \mathrm{REV}(-3)\right)$} & -0.285477 & 0.285902 & -0.177042 & 0.262588 & 0.287302 & -0.386005 & 0.006146 \\
\hline & $(0.59411)$ & $(0.18839)$ & $(0.10972)$ & $(0.46958)$ & $(1.29976)$ & $(0.37812)$ & $(0.06773)$ \\
\hline & {$[-0.48051]$} & {$[1.51758]$} & {$[-1.61351]$} & [0.55919] & {$[0.22104]$} & {$[-1.02085]$} & {$[0.09074]$} \\
\hline \multirow{3}{*}{ D(L_BLACKREV $(-1))$} & 0.052260 & -0.040536 & 0.010966 & -0.328045 & -0.312090 & 0.071374 & -0.009881 \\
\hline & $(0.15137)$ & $(0.04800)$ & $(0.02796)$ & $(0.11964)$ & $(0.33116)$ & $(0.09634)$ & $(0.01726)$ \\
\hline & {$[0.34525]$} & {$[-0.84452]$} & {$[0.39225]$} & {$[-2.74190]$} & {$[-0.94242]$} & {$[0.74086]$} & {$[-0.57263]$} \\
\hline \multirow{3}{*}{ D(L_BLACKREV(-2)) } & 0.076169 & -0.124167 & 0.031313 & -0.257124 & -0.127328 & 0.181062 & 0.003592 \\
\hline & $(0.15511)$ & $(0.04919)$ & $(0.02865)$ & $(0.12260)$ & $(0.33934)$ & $(0.09872)$ & $(0.01768)$ \\
\hline & [0.49107] & {$[-2.52449]$} & [1.09309] & {$[-2.09731]$} & {$[-0.37522]$} & [1.83412] & {$[0.20315]$} \\
\hline \multirow{3}{*}{ D(L_BLACKREV $(-3))$} & 0.218240 & -0.134015 & 0.041642 & 0.599701 & -0.328717 & 0.042652 & -0.000175 \\
\hline & $(0.17667)$ & $(0.05602)$ & $(0.03263)$ & $(0.13964)$ & $(0.38652)$ & $(0.11244)$ & $(0.02014)$ \\
\hline & {$[1.23528]$} & {$[-2.39212]$} & {$[1.27621]$} & {$[4.29453]$} & {$[-0.85046]$} & {$[0.37932]$} & {$[-0.00871]$} \\
\hline \multirow{3}{*}{ D(L_MOBVREV $(-1))$} & -0.012301 & -0.012981 & -0.008424 & -0.027298 & -0.513666 & 0.008880 & 0.004750 \\
\hline & $(0.05679)$ & $(0.01801)$ & $(0.01049)$ & $(0.04489)$ & $(0.12425)$ & $(0.03615)$ & $(0.00647)$ \\
\hline & {$[-0.21660]$} & {$[-0.72077]$} & {$[-0.80316]$} & {$[-0.60813]$} & {$[-4.13413]$} & {$[0.24566]$} & {$[0.73360]$} \\
\hline \multirow{3}{*}{ D(L_MOBVREV(-2)) } & 0.086455 & -0.016921 & -0.013322 & -0.027596 & -0.089275 & -0.073529 & 0.003157 \\
\hline & $(0.05811)$ & $(0.01843)$ & $(0.01073)$ & $(0.04593)$ & $(0.12712)$ & $(0.03698)$ & $(0.00662)$ \\
\hline & {$[1.48790]$} & {$[-0.91832]$} & {$[-1.24144]$} & {$[-0.60087]$} & {$[-0.70228]$} & {$[-1.98826]$} & {$[0.47651]$} \\
\hline \multirow{3}{*}{ D(L_MOBVREV(-3)) } & 0.057666 & 0.015809 & -0.002281 & 0.027458 & 0.062586 & -0.055097 & 0.009887 \\
\hline & $(0.05397)$ & $(0.01711)$ & $(0.00997)$ & $(0.04266)$ & $(0.11807)$ & $(0.03435)$ & $(0.00615)$ \\
\hline & [1.06853] & {$[0.92378]$} & {$[-0.22887]$} & {$[0.64370]$} & {$[0.53009]$} & {$[-1.60411]$} & {$[1.60700]$} \\
\hline
\end{tabular}


Continued

\begin{tabular}{|c|c|c|c|c|c|c|c|}
\hline \multirow{3}{*}{$\mathrm{D}\left(\mathrm{L} \_\right.$NEERREV $\left.(-1)\right)$} & -0.310742 & 0.191160 & -0.007976 & 0.175869 & 0.618178 & -0.212729 & 0.012863 \\
\hline & $(0.19772)$ & $(0.06270)$ & $(0.03652)$ & $(0.15628)$ & $(0.43256)$ & $(0.12584)$ & $(0.02254)$ \\
\hline & {$[-1.57162]$} & [3.04891] & {$[-0.21841]$} & [1.12535] & [1.42910] & {$[-1.69048]$} & {$[0.57064]$} \\
\hline \multirow{3}{*}{$\mathrm{D}\left(\mathrm{L} \_\right.$NEERREV $\left.(-2)\right)$} & 0.076955 & 0.106417 & -0.038101 & 0.005999 & 0.158729 & -0.139824 & 0.044692 \\
\hline & $(0.18997)$ & $(0.06024)$ & $(0.03509)$ & $(0.15015)$ & $(0.41561)$ & $(0.12091)$ & $(0.02166)$ \\
\hline & [0.40509] & {$[1.76655]$} & {$[-1.08595]$} & {$[0.03996]$} & [0.38192] & {$[-1.15647]$} & [2.06366] \\
\hline \multirow{3}{*}{ D(L_NEERREV $(-3))$} & -0.168331 & 0.045585 & 0.052134 & -0.003434 & -0.328174 & 0.165249 & 0.042039 \\
\hline & $(0.18165)$ & $(0.05760)$ & $(0.03355)$ & $(0.14358)$ & $(0.39741)$ & $(0.11561)$ & $(0.02071)$ \\
\hline & {$[-0.92667]$} & [0.79137] & [1.55397] & {$[-0.02391]$} & {$[-0.82578]$} & {$[1.42934]$} & {$[2.03002]$} \\
\hline \multirow{3}{*}{$\mathrm{D}\left(\mathrm{L} \_\mathrm{CPI}(-1)\right)$} & -2.017771 & 1.163614 & -0.298173 & 1.270143 & 0.089066 & -0.276496 & 0.414029 \\
\hline & $(0.90112)$ & $(0.28575)$ & $(0.16643)$ & $(0.71225)$ & $(1.97143)$ & $(0.57352)$ & $(0.10273)$ \\
\hline & {$[-2.23918]$} & {$[4.07218]$} & {$[-1.79162]$} & [1.78329] & {$[0.04518]$} & {$[-0.48211]$} & [4.03027] \\
\hline \multirow{3}{*}{$\mathrm{D}\left(\mathrm{L} \_\mathrm{CPI}(-2)\right)$} & -0.752605 & 0.015180 & 0.379923 & 0.135595 & 2.104944 & 0.300270 & 0.259912 \\
\hline & $(1.13955)$ & $(0.36135)$ & $(0.21046)$ & $(0.90070)$ & $(2.49305)$ & $(0.72526)$ & $(0.12991)$ \\
\hline & {$[-0.66044]$} & {$[0.04201]$} & {$[1.80520]$} & {$[0.15054]$} & {$[0.84433]$} & {$[0.41402]$} & [2.00070] \\
\hline \multirow{3}{*}{$\mathrm{D}\left(\mathrm{L} \_\mathrm{CPI}(-3)\right)$} & 1.537178 & -0.560325 & 0.133290 & -1.233281 & 2.562298 & -1.117209 & 0.022020 \\
\hline & $(1.11098)$ & $(0.35229)$ & $(0.20518)$ & $(0.87812)$ & $(2.43055)$ & $(0.70708)$ & $(0.12665)$ \\
\hline & [1.38363] & {$[-1.59050]$} & {$[0.64961]$} & {$[-1.40446]$} & [1.05421] & {$[-1.58003]$} & {$[0.17386]$} \\
\hline \multirow{3}{*}{$\mathrm{C}$} & 0.000332 & 0.008605 & -0.002719 & 0.015984 & 0.017591 & 0.002714 & 0.001301 \\
\hline & $(0.00796)$ & $(0.00253)$ & $(0.00147)$ & $(0.00629)$ & $(0.01742)$ & $(0.00507)$ & $(0.00091)$ \\
\hline & {$[0.04166]$} & [3.40751] & {$[-1.84846]$} & [2.53923] & [1.00965] & {$[0.53536]$} & [1.43330] \\
\hline R-squared & 0.695695 & 0.924109 & 0.397405 & 0.732313 & 0.396053 & 0.342215 & 0.599043 \\
\hline Adj. R-squared & 0.594260 & 0.898811 & 0.196540 & 0.643085 & 0.194737 & 0.122953 & 0.465391 \\
\hline Sum sq. resids & 0.092475 & 0.009299 & 0.003154 & 0.057772 & 0.442611 & 0.037459 & 0.001202 \\
\hline S. E. equation & 0.037432 & 0.011870 & 0.006913 & 0.029586 & 0.081892 & 0.023823 & 0.004267 \\
\hline F-statistic & 6.858525 & 36.53013 & 1.978466 & 8.207139 & 1.967323 & 1.560760 & 4.482107 \\
\hline Log likelihood & 179.4051 & 281.6242 & 329.7337 & 200.3393 & 109.7291 & 219.6198 & 372.6718 \\
\hline Akaike AIC & -3.514721 & -5.811779 & -6.892892 & -3.985152 & -1.948968 & -4.418421 & -7.857794 \\
\hline Schwarz SC & -2.871590 & -5.168648 & -6.249761 & -3.342021 & -1.305838 & -3.775291 & -7.214663 \\
\hline Mean dependent & 0.006904 & 0.004269 & -0.001041 & 0.012095 & 0.021105 & -0.000531 & 0.004127 \\
\hline S. D. dependent & 0.058765 & 0.037314 & 0.007713 & 0.049523 & 0.091258 & 0.025439 & 0.005836 \\
\hline \multicolumn{2}{|c|}{ Determinant resid covariance (dof adj.) } & $3.81 \mathrm{E}-25$ & & & & & \\
\hline \multicolumn{2}{|c|}{ Determinant resid covariance } & $4.71 \mathrm{E}-26$ & & & & & \\
\hline \multicolumn{2}{|l|}{ Log likelihood } & 1711.178 & & & & & \\
\hline \multicolumn{2}{|c|}{ Akaike information criterion } & -34.65568 & & & & & \\
\hline \multicolumn{2}{|l|}{ Schwarz criterion } & -29.93007 & & & & & \\
\hline \multicolumn{2}{|l|}{ Number of coefficients } & 169 & & & & & \\
\hline
\end{tabular}




\section{Appendix 2.4. Demand for Cash: 10,000 Notes Denomination}

Vector Error Correction Estimates

Date: 12/28/19 Time: 09:27

Sample (adjusted): 2012M05 2019M09

Included observations: 89 after adjustments

Standard errors in ( ) \& t-statistics in [ ]

\begin{tabular}{|c|c|c|c|c|c|c|c|}
\hline Cointegrating Eq: & CointEq1 & & & & & & \\
\hline L_N10(-1) & 1.000000 & & & & & & \\
\hline L_RGDP15(-1) & $\begin{array}{c}-6.355025 \\
(1.99651) \\
{[-3.18307]}\end{array}$ & & & & & & \\
\hline R_3REV(-1) & $\begin{array}{l}6.201132 \\
(2.61422) \\
{[2.37208]}\end{array}$ & & & & & & \\
\hline L_BLACKREV $(-1)$ & $\begin{array}{c}-1.771687 \\
(0.95581) \\
{[-1.85360]}\end{array}$ & & & & & & \\
\hline L_MOBVREV(-1) & $\begin{array}{l}1.597664 \\
(0.27034) \\
{[5.90977]}\end{array}$ & & & & & & \\
\hline L_NEERREV $(-1)$ & $\begin{array}{l}1.452689 \\
(0.60993) \\
{[2.38171]}\end{array}$ & & & & & & \\
\hline L_CPI(-1) & $\begin{array}{c}-4.568381 \\
(2.10781) \\
{[-2.16736]}\end{array}$ & & & & & & \\
\hline @TREND(12M01) & 0.045043 & & & & & & \\
\hline $\mathrm{C}$ & 3.174367 & & & & & & \\
\hline Error Correction: & $\mathrm{D}\left(\mathrm{L} \_\mathrm{N} 10\right)$ & D(L_RGDP15) & $\mathrm{D}$ (R_3REV) & D(L_BLACKREV) & D(L_MOBVREV) & $\mathrm{D}\left(\mathrm{L} \_\right.$NEERREV $)$ & $\mathrm{D}\left(\mathrm{L} \_\mathrm{CPI}\right)$ \\
\hline CointEq1 & $\begin{array}{c}-0.206758 \\
(0.10166) \\
{[-2.03373]}\end{array}$ & $\begin{array}{c}-0.044892 \\
(0.01072) \\
{[-4.18820]}\end{array}$ & $\begin{array}{c}-0.007557 \\
(0.00626) \\
{[-1.20756]}\end{array}$ & $\begin{array}{c}-0.034352 \\
(0.02584) \\
{[-1.32947]}\end{array}$ & $\begin{array}{c}-0.268141 \\
(0.06315) \\
{[-4.24592]}\end{array}$ & $\begin{array}{c}-0.011569 \\
(0.02073) \\
{[-0.55814]}\end{array}$ & $\begin{array}{c}-0.000367 \\
(0.00374) \\
{[-0.09823]}\end{array}$ \\
\hline $\mathrm{D}\left(\mathrm{L} \_\mathrm{N} 10(-1)\right)$ & $\begin{array}{c}-0.032618 \\
(0.09004) \\
{[-0.36227]}\end{array}$ & $\begin{array}{c}-0.279800 \\
(0.05798) \\
{[-4.82545]}\end{array}$ & $\begin{array}{l}0.032211 \\
(0.03385) \\
{[0.95148]}\end{array}$ & $\begin{array}{c}-0.093771 \\
(0.13978) \\
{[-0.67085]}\end{array}$ & $\begin{array}{l}0.838982 \\
(0.34163) \\
{[2.45581]}\end{array}$ & $\begin{array}{l}0.044278 \\
(0.11213) \\
{[0.39489]}\end{array}$ & $\begin{array}{c}-0.059760 \\
(0.02024) \\
{[-2.95319]}\end{array}$ \\
\hline $\mathrm{D}\left(\mathrm{L} \_\mathrm{N} 10(-2)\right)$ & $\begin{array}{c}-0.127083 \\
(0.11676) \\
{[-1.08838]}\end{array}$ & $\begin{array}{c}-0.031288 \\
(0.07520) \\
{[-0.41608]}\end{array}$ & $\begin{array}{l}0.017605 \\
(0.04390) \\
{[0.40100]}\end{array}$ & $\begin{array}{l}0.068926 \\
(0.18127) \\
{[0.38023]}\end{array}$ & $\begin{array}{l}0.292635 \\
(0.44304) \\
{[0.66051]}\end{array}$ & $\begin{array}{l}0.150872 \\
(0.14541) \\
{[1.03756]}\end{array}$ & $\begin{array}{c}-0.028480 \\
(0.02624) \\
{[-1.08527]}\end{array}$ \\
\hline
\end{tabular}


C. A. Kombe et al.

\section{Continued}

\begin{tabular}{|c|c|c|c|c|c|c|c|}
\hline \multirow{3}{*}{$\mathrm{D}\left(\mathrm{L} \_\mathrm{N} 10(-3)\right)$} & 0.312610 & 0.041427 & -0.011471 & -0.011383 & 0.846961 & 0.098118 & -0.041365 \\
\hline & $(0.11314)$ & $(0.07286)$ & $(0.04254)$ & $(0.17565)$ & $(0.42930)$ & $(0.14090)$ & $(0.02543)$ \\
\hline & {$[2.76302]$} & {$[0.56856]$} & {$[-0.26966]$} & {$[-0.06481]$} & [1.97290] & {$[0.69638]$} & {$[-1.62675]$} \\
\hline \multirow{3}{*}{ D(L_RGDP15(-1)) } & -0.674715 & 0.521332 & 0.012733 & 0.942831 & 0.520997 & -0.003362 & 0.052052 \\
\hline & $(0.15773)$ & $(0.10158)$ & $(0.05930)$ & $(0.24487)$ & $(0.59847)$ & $(0.19642)$ & $(0.03545)$ \\
\hline & {$[-4.27775]$} & [5.13238] & {$[0.21471]$} & [3.85038] & {$[0.87054]$} & {$[-0.01712]$} & [1.46835] \\
\hline \multirow{3}{*}{ D(L_RGDP15(-2)) } & 0.987805 & -0.033866 & -0.009799 & 0.140316 & 0.140526 & -0.136444 & -0.086775 \\
\hline & $(0.17593)$ & $(0.11330)$ & $(0.06615)$ & $(0.27313)$ & $(0.66755)$ & $(0.21909)$ & $(0.03954)$ \\
\hline & [5.61473] & {$[-0.29890]$} & {$[-0.14814]$} & {$[0.51373]$} & {$[0.21051]$} & {$[-0.62277]$} & {$[-2.19458]$} \\
\hline \multirow{3}{*}{ D(L_RGDP15(-3)) } & -1.048809 & -0.435884 & -0.035257 & -0.956086 & -0.771821 & 0.022114 & 0.085718 \\
\hline & $(0.15729)$ & $(0.10129)$ & $(0.05914)$ & $(0.24419)$ & $(0.59681)$ & $(0.19588)$ & $(0.03535)$ \\
\hline & {$[-6.66808]$} & {$[-4.30313]$} & {$[-0.59616]$} & {$[-3.91540]$} & {$[-1.29325]$} & {$[0.11290]$} & [2.42481] \\
\hline \multirow{3}{*}{ D(R_3REV(-1)) } & -0.282882 & -0.055980 & 0.137466 & 0.001174 & 1.284008 & -0.183037 & 0.033024 \\
\hline & $(0.33451)$ & $(0.21542)$ & $(0.12577)$ & $(0.51931)$ & $(1.26924)$ & $(0.41657)$ & $(0.07518)$ \\
\hline & {$[-0.84567]$} & {$[-0.25986]$} & {$[1.09297]$} & {$[0.00226]$} & {$[1.01164]$} & {$[-0.43939]$} & {$[0.43926]$} \\
\hline \multirow{3}{*}{$\mathrm{D}\left(\mathrm{R} \_3 \operatorname{REV}(-2)\right)$} & 0.240551 & -0.248274 & -0.194872 & -0.219528 & 0.873684 & -0.952963 & -0.061626 \\
\hline & $(0.30045)$ & $(0.19349)$ & $(0.11297)$ & $(0.46643)$ & $(1.14000)$ & $(0.37415)$ & $(0.06753)$ \\
\hline & {$[0.80065]$} & {$[-1.28314]$} & {$[-1.72505]$} & {$[-0.47065]$} & [0.76639] & {$[-2.54698]$} & {$[-0.91264]$} \\
\hline \multirow{3}{*}{$\mathrm{D}\left(\mathrm{R} \_3 \operatorname{REV}(-3)\right)$} & -0.041608 & 0.119872 & -0.251725 & 0.151232 & 1.477157 & -0.277696 & 0.014033 \\
\hline & $(0.32509)$ & $(0.20936)$ & $(0.12223)$ & $(0.50470)$ & $(1.23352)$ & $(0.40485)$ & $(0.07306)$ \\
\hline & {$[-0.12799]$} & {$[0.57256]$} & {$[-2.05937]$} & {$[0.29965]$} & [1.19751] & {$[-0.68592]$} & [0.19207] \\
\hline \multirow{3}{*}{ D(L_BLACKREV $(-1))$} & 0.041485 & 0.112904 & 0.039718 & -0.263020 & -0.967266 & 0.005981 & 0.003705 \\
\hline & $(0.09910)$ & $(0.06382)$ & $(0.03726)$ & $(0.15385)$ & $(0.37603)$ & $(0.12342)$ & $(0.02227)$ \\
\hline & {$[0.41861]$} & [1.76902] & {$[1.06591]$} & {$[-1.70954]$} & {$[-2.57230]$} & {$[0.04846]$} & {$[0.16632]$} \\
\hline \multirow{3}{*}{ D(L_BLACKREV(-2)) } & 0.025813 & 0.053407 & 0.057118 & -0.147086 & -0.934625 & 0.120455 & 0.022014 \\
\hline & $(0.10102)$ & $(0.06506)$ & $(0.03798)$ & $(0.15683)$ & $(0.38331)$ & $(0.12580)$ & $(0.02270)$ \\
\hline & {$[0.25552]$} & {$[0.82093]$} & {$[1.50376]$} & {$[-0.93786]$} & {$[-2.43832]$} & [0.95749] & {$[0.96960]$} \\
\hline \multirow{3}{*}{ D(L_BLACKREV(-3)) } & 0.116977 & 0.022144 & 0.061091 & 0.681164 & -0.834823 & 0.012512 & 0.018202 \\
\hline & $(0.10256)$ & $(0.06605)$ & $(0.03856)$ & $(0.15923)$ & $(0.38917)$ & $(0.12773)$ & $(0.02305)$ \\
\hline & {$[1.14052]$} & {$[0.33524]$} & {$[1.58416]$} & {$[4.27791]$} & {$[-2.14516]$} & {$[0.09796]$} & {$[0.78963]$} \\
\hline \multirow{3}{*}{$\mathrm{D}\left(\mathrm{L} \_\right.$MOBVREV $\left.(-1)\right)$} & -0.021640 & -0.044052 & -0.000197 & -0.040505 & -0.311514 & -0.012107 & 0.001269 \\
\hline & $(0.03018)$ & $(0.01944)$ & $(0.01135)$ & $(0.04686)$ & $(0.11452)$ & $(0.03759)$ & $(0.00678)$ \\
\hline & {$[-0.71698]$} & {$[-2.26630]$} & {$[-0.01734]$} & {$[-0.86442]$} & {$[-2.72007]$} & {$[-0.32209]$} & {$[0.18700]$} \\
\hline \multirow{3}{*}{$\mathrm{D}\left(\mathrm{L} \_\mathrm{MOBVREV}(-2)\right)$} & 0.048393 & -0.028771 & -0.005749 & -0.011268 & -0.136723 & -0.092095 & -0.004072 \\
\hline & $(0.03074)$ & $(0.01979)$ & $(0.01156)$ & $(0.04772)$ & $(0.11663)$ & $(0.03828)$ & $(0.00691)$ \\
\hline & {$[1.57444]$} & {$[-1.45346]$} & {$[-0.49741]$} & {$[-0.23613]$} & {$[-1.17232]$} & {$[-2.40600]$} & {$[-0.58949]$} \\
\hline \multirow{3}{*}{$\mathrm{D}\left(\mathrm{L} \_\right.$MOBVREV $\left.(-3)\right)$} & 0.018160 & 0.025679 & 0.000703 & 0.054536 & 0.049242 & -0.059485 & 0.009030 \\
\hline & $(0.02885)$ & $(0.01858)$ & $(0.01085)$ & $(0.04479)$ & $(0.10948)$ & $(0.03593)$ & $(0.00648)$ \\
\hline & {$[0.62940]$} & [1.38199] & {$[0.06484]$} & [1.21751] & [0.44979] & {$[-1.65553]$} & [1.39255] \\
\hline \multirow{3}{*}{ D(L_NEERREV $(-1))$} & 0.016152 & -0.069838 & -0.039768 & -0.071219 & 0.931389 & -0.139060 & -0.017797 \\
\hline & $(0.09727)$ & $(0.06264)$ & $(0.03657)$ & $(0.15101)$ & $(0.36909)$ & $(0.12114)$ & $(0.02186)$ \\
\hline & {$[0.16605]$} & {$[-1.11483]$} & {$[-1.08732]$} & {$[-0.47160]$} & [2.52348] & {$[-1.14795]$} & {$[-0.81408]$} \\
\hline
\end{tabular}




\section{Continued}

\begin{tabular}{|c|c|c|c|c|c|c|c|}
\hline \multirow{3}{*}{$\mathrm{D}\left(\mathrm{L} \_\right.$NEERREV $\left.(-2)\right)$} & 0.033786 & -0.069437 & -0.078328 & -0.183868 & 0.310424 & -0.034854 & 0.013934 \\
\hline & $(0.09263)$ & $(0.05965)$ & $(0.03483)$ & $(0.14380)$ & $(0.35146)$ & $(0.11535)$ & $(0.02082)$ \\
\hline & {$[0.36475]$} & {$[-1.16404]$} & {$[-2.24906]$} & {$[-1.27865]$} & [0.88325] & {$[-0.30216]$} & [0.66936] \\
\hline \multirow{3}{*}{$\mathrm{D}\left(\mathrm{L} \_\right.$NEERREV $\left.(-3)\right)$} & 0.154983 & -0.108663 & 0.023439 & -0.211143 & 0.206078 & 0.236873 & 0.018017 \\
\hline & $(0.09135)$ & $(0.05883)$ & $(0.03435)$ & $(0.14182)$ & $(0.34661)$ & $(0.11376)$ & $(0.02053)$ \\
\hline & {$[1.69660]$} & {$[-1.84708]$} & {$[0.68241]$} & {$[-1.48884]$} & {$[0.59455]$} & {$[2.08222]$} & {$[0.87754]$} \\
\hline \multirow{3}{*}{$\mathrm{D}\left(\mathrm{L} \_\mathrm{CPI}(-1)\right)$} & -0.525305 & 1.323267 & -0.265287 & 1.903590 & -2.239122 & -0.075313 & 0.293501 \\
\hline & $(0.51290)$ & $(0.33031)$ & $(0.19285)$ & $(0.79626)$ & $(1.94612)$ & $(0.63873)$ & $(0.11527)$ \\
\hline & {$[-1.02419]$} & {$[4.00615]$} & {$[-1.37563]$} & [2.39066] & {$[-1.15056]$} & {$[-0.11791]$} & [2.54613] \\
\hline \multirow{3}{*}{$\mathrm{D}\left(\mathrm{L} \_\mathrm{CPI}(-2)\right)$} & -0.244640 & 0.125903 & 0.333890 & 0.244333 & -4.501696 & 0.663544 & 0.035014 \\
\hline & $(0.57898)$ & $(0.37287)$ & $(0.21769)$ & $(0.89885)$ & $(2.19687)$ & $(0.72102)$ & $(0.13013)$ \\
\hline & {$[-0.42254]$} & {$[0.33766]$} & {$[1.53375]$} & {$[0.27183]$} & {$[-2.04915]$} & {$[0.92028]$} & {$[0.26908]$} \\
\hline \multirow{3}{*}{$\mathrm{D}\left(\mathrm{L} \_\mathrm{CPI}(-3)\right)$} & 0.687525 & -0.557542 & 0.017058 & -1.069798 & -4.194572 & -0.494545 & -0.233944 \\
\hline & $(0.60832)$ & $(0.39176)$ & $(0.22872)$ & $(0.94440)$ & $(2.30818)$ & $(0.75756)$ & $(0.13672)$ \\
\hline & [1.13021] & {$[-1.42318]$} & {$[0.07458]$} & {$[-1.13279]$} & {$[-1.81727]$} & {$[-0.65282]$} & {$[-1.71113]$} \\
\hline \multirow{3}{*}{$\mathrm{C}$} & 0.010601 & 0.002511 & -0.004309 & -0.007820 & 0.142303 & -0.002487 & 0.006736 \\
\hline & $(0.00991)$ & $(0.00638)$ & $(0.00373)$ & $(0.01539)$ & $(0.03760)$ & $(0.01234)$ & $(0.00223)$ \\
\hline & [1.06961] & {$[0.39336]$} & {$[-1.15638]$} & {$[-0.50825]$} & {$[3.78414]$} & {$[-0.20152]$} & [3.02407] \\
\hline \multirow{3}{*}{ @TREND(12M01) } & $-6.26 \mathrm{E}-05$ & $-3.12 \mathrm{E}-05$ & $1.03 \mathrm{E}-05$ & 0.000247 & -0.000856 & $1.46 \mathrm{E}-05$ & $-5.79 \mathrm{E}-05$ \\
\hline & $(0.00011)$ & $(7.0 \mathrm{E}-05)$ & $(4.1 \mathrm{E}-05)$ & $(0.00017)$ & $(0.00041)$ & $(0.00014)$ & $(2.4 \mathrm{E}-05)$ \\
\hline & {$[-0.57463]$} & {$[-0.44430]$} & {$[0.25130]$} & [1.45879] & {$[-2.06948]$} & {$[0.10738]$} & {$[-2.36434]$} \\
\hline R-squared & 0.625061 & 0.916140 & 0.330893 & 0.723330 & 0.513300 & 0.325304 & 0.582507 \\
\hline Adj. R-squared & 0.492390 & 0.886467 & 0.094132 & 0.625431 & 0.341084 & 0.086565 & 0.434778 \\
\hline Sum sq. resids & 0.024775 & 0.010275 & 0.003502 & 0.059711 & 0.356685 & 0.038422 & 0.001251 \\
\hline S. E. equation & 0.019523 & 0.012573 & 0.007341 & 0.030309 & 0.074077 & 0.024313 & 0.004388 \\
\hline F-statistic & 4.711362 & 30.87406 & 1.397582 & 7.388552 & 2.980547 & 1.362594 & 3.943094 \\
\hline Log likelihood & 238.0170 & 277.1812 & 325.0746 & 198.8703 & 119.3339 & 218.4902 & 370.8734 \\
\hline Akaike AIC & -4.809372 & -5.689465 & -6.765722 & -3.929670 & -2.142336 & -4.370565 & -7.794907 \\
\hline Schwarz SC & -4.138279 & -5.018372 & -6.094629 & -3.258577 & -1.471243 & -3.699472 & -7.123814 \\
\hline Mean dependent & 0.008122 & 0.004269 & -0.001041 & 0.012095 & 0.021105 & -0.000531 & 0.004127 \\
\hline S. D. dependent & 0.027402 & 0.037314 & 0.007713 & 0.049523 & 0.091258 & 0.025439 & 0.005836 \\
\hline \multicolumn{2}{|c|}{ Determinant resid covariance (dof adj.) } & $8.37 \mathrm{E}-26$ & & & & & \\
\hline \multicolumn{2}{|c|}{ Determinant resid covariance } & $9.28 \mathrm{E}-27$ & & & & & \\
\hline \multicolumn{2}{|l|}{ Log likelihood } & 1783.432 & & & & & \\
\hline \multicolumn{2}{|c|}{ Akaike information criterion } & -36.14455 & & & & & \\
\hline \multicolumn{2}{|l|}{ Schwarz criterion } & -31.25116 & & & & & \\
\hline \multicolumn{2}{|l|}{ Number of coefficients } & 175 & & & & & \\
\hline
\end{tabular}




\section{Appendix 2.5. Demand for Cash: All Cash}

Vector Error Correction Estimates

Date: 12/28/19 Time: 09:52

Sample (adjusted): 2012M05 2019M09

Included observations: 89 after adjustments

Standard errors in ( ) \& t-statistics in [ ]

\begin{tabular}{|c|c|c|c|c|c|c|c|}
\hline Cointegrating Eq: & CointEq1 & & & & & & \\
\hline L_CC $(-1)$ & 1.000000 & & & & & & \\
\hline L_RGDP15(-1) & $\begin{array}{c}-3.934100 \\
(1.47289) \\
{[-2.67101]}\end{array}$ & & & & & & \\
\hline R_3REV $(-1)$ & $\begin{array}{l}4.037858 \\
(1.97204) \\
{[2.04755]}\end{array}$ & & & & & & \\
\hline L_BLACKREV(-1) & $\begin{array}{c}-1.246119 \\
(0.69920) \\
{[-1.78221]}\end{array}$ & & & & & & \\
\hline L_MOBVREV(-1) & $\begin{array}{l}1.126389 \\
(0.20365) \\
{[5.53111]}\end{array}$ & & & & & & \\
\hline L_NEERREV (-1) & $\begin{array}{l}0.998208 \\
(0.46707) \\
{[2.13719]}\end{array}$ & & & & & & \\
\hline L_CPI(-1) & $\begin{array}{c}-4.376856 \\
(1.57833) \\
{[-2.77310]}\end{array}$ & & & & & & \\
\hline @TREND(12M01) & $\begin{array}{l}0.032403 \\
(0.01103) \\
{[2.93821]}\end{array}$ & & & & & & \\
\hline C & 4.981307 & & & & & & \\
\hline Error Correction: & $\mathrm{D}\left(\mathrm{L} \_\mathrm{CC}\right)$ & D(L_RGDP15) & $\mathrm{D}$ (R_3REV) & D(L_BLACKREV) & D(L_MOBVREV) & $\mathrm{D}\left(\mathrm{L} \_\right.$NEERREV $)$ & $\mathrm{D}\left(\mathrm{L} \_\mathrm{CPI}\right)$ \\
\hline CointEq1 & $\begin{array}{c}-0.249118 \\
(0.11336) \\
{[-2.19758]}\end{array}$ & $\begin{array}{c}-0.057475 \\
(0.01432) \\
{[-4.01299]}\end{array}$ & $\begin{array}{c}-0.013097 \\
(0.00839) \\
{[-1.56170]}\end{array}$ & $\begin{array}{c}-0.050996 \\
(0.03534) \\
{[-1.44312]}\end{array}$ & $\begin{array}{c}-0.373187 \\
(0.08852) \\
{[-4.21564]}\end{array}$ & $\begin{array}{c}-0.013818 \\
(0.02837) \\
{[-0.48714]}\end{array}$ & $\begin{array}{c}-0.000356 \\
(0.00532) \\
{[-0.06691]}\end{array}$ \\
\hline $\mathrm{D}\left(\mathrm{L} \_\mathrm{CC}(-1)\right)$ & $\begin{array}{l}0.011974 \\
(0.08402) \\
{[0.14251]}\end{array}$ & $\begin{array}{c}-0.257758 \\
(0.05151) \\
{[-5.00422]}\end{array}$ & $\begin{array}{l}0.033662 \\
(0.03016) \\
{[1.11614]}\end{array}$ & $\begin{array}{c}-0.169504 \\
(0.12709) \\
{[-1.33377]}\end{array}$ & $\begin{array}{l}0.793665 \\
(0.31837) \\
{[2.49294]}\end{array}$ & $\begin{array}{l}0.031692 \\
(0.10202) \\
{[0.31066]}\end{array}$ & $\begin{array}{c}-0.042840 \\
(0.01914) \\
{[-2.23806]}\end{array}$ \\
\hline
\end{tabular}




\section{Continued}

\begin{tabular}{|c|c|c|c|c|c|c|c|}
\hline \multirow{3}{*}{$\mathrm{D}\left(\mathrm{L} \_\mathrm{CC}(-2)\right)$} & -0.047786 & -0.030399 & 0.028902 & -0.025526 & 0.401529 & 0.073064 & -0.026395 \\
\hline & $(0.10763)$ & $(0.06598)$ & $(0.03863)$ & $(0.16279)$ & $(0.40782)$ & $(0.13068)$ & $(0.02452)$ \\
\hline & {$[-0.44398]$} & {$[-0.46073]$} & {$[0.74810]$} & {$[-0.15680]$} & {$[0.98458]$} & {$[0.55911]$} & {$[-1.07648]$} \\
\hline \multirow{3}{*}{$\mathrm{D}\left(\mathrm{L} \_\mathrm{CC}(-3)\right)$} & 0.357667 & 0.083858 & -0.029194 & -0.018012 & 0.867996 & 0.070620 & -0.018429 \\
\hline & $(0.10759)$ & $(0.06596)$ & $(0.03862)$ & $(0.16274)$ & $(0.40767)$ & $(0.13063)$ & $(0.02451)$ \\
\hline & [3.32429] & [1.27141] & {$[-0.75593]$} & {$[-0.11068]$} & [2.12916] & {$[0.54060]$} & {$[-0.75187]$} \\
\hline \multirow{3}{*}{ D(L_RGDP15(-1)) } & -0.525130 & 0.482620 & 0.025637 & 0.812549 & 0.917242 & -0.039536 & 0.049202 \\
\hline & $(0.15994)$ & $(0.09804)$ & $(0.05741)$ & $(0.24191)$ & $(0.60600)$ & $(0.19418)$ & $(0.03644)$ \\
\hline & {$[-3.28339]$} & [4.92245] & {$[0.44657]$} & [3.35895] & {$[1.51360]$} & {$[-0.20360]$} & [1.35037] \\
\hline \multirow{3}{*}{ D(L_RGDP15(-2)) } & 0.940374 & 0.019874 & -0.035651 & 0.173954 & 0.163530 & -0.129318 & -0.058835 \\
\hline & $(0.18108)$ & $(0.11101)$ & $(0.06500)$ & $(0.27388)$ & $(0.68611)$ & $(0.21985)$ & $(0.04125)$ \\
\hline & {$[5.19320]$} & {$[0.17904]$} & {$[-0.54850]$} & {$[0.63514]$} & {$[0.23834]$} & {$[-0.58820]$} & {$[-1.42622]$} \\
\hline \multirow{3}{*}{ D(L_RGDP15(-3)) } & -0.947980 & -0.490694 & -0.028684 & -1.040480 & -0.409888 & 0.021089 & 0.083019 \\
\hline & $(0.15976)$ & $(0.09794)$ & $(0.05735)$ & $(0.24165)$ & $(0.60535)$ & $(0.19398)$ & $(0.03640)$ \\
\hline & {$[-5.93360]$} & {$[-5.01016]$} & {$[-0.50018]$} & {$[-4.30578]$} & {$[-0.67711]$} & {$[0.10872]$} & [2.28094] \\
\hline \multirow{3}{*}{$\mathrm{D}\left(\mathrm{R} \_3 \operatorname{REV}(-1)\right)$} & -0.053022 & -0.084897 & 0.128567 & 0.004936 & 1.162202 & -0.165742 & 0.014919 \\
\hline & $(0.34180)$ & $(0.20953)$ & $(0.12269)$ & $(0.51697)$ & $(1.29508)$ & $(0.41499)$ & $(0.07787)$ \\
\hline & {$[-0.15513]$} & {$[-0.40518]$} & {$[1.04794]$} & {$[0.00955]$} & {$[0.89740]$} & {$[-0.39939]$} & {$[0.19160]$} \\
\hline \multirow{3}{*}{$\mathrm{D}\left(\mathrm{R} \_3 \mathrm{REV}(-2)\right)$} & 0.053641 & -0.201590 & -0.188243 & -0.245458 & 0.771971 & -0.964725 & -0.054846 \\
\hline & $(0.30778)$ & $(0.18867)$ & $(0.11047)$ & $(0.46552)$ & $(1.16617)$ & $(0.37368)$ & $(0.07012)$ \\
\hline & {$[0.17429]$} & {$[-1.06845]$} & {$[-1.70395]$} & {$[-0.52728]$} & [0.66197] & {$[-2.58168]$} & {$[-0.78222]$} \\
\hline \multirow{3}{*}{$\mathrm{D}\left(\mathrm{R} \_3 \mathrm{REV}(-3)\right)$} & 0.202889 & 0.082426 & -0.255546 & 0.085445 & 1.650583 & -0.295546 & 0.000243 \\
\hline & $(0.33086)$ & $(0.20283)$ & $(0.11876)$ & $(0.50043)$ & $(1.25364)$ & $(0.40171)$ & $(0.07537)$ \\
\hline & {$[0.61322]$} & {$[0.40639]$} & {$[-2.15177]$} & {$[0.17074]$} & {$[1.31663]$} & {$[-0.73572]$} & {$[0.00322]$} \\
\hline \multirow{3}{*}{ D(L_BLACKREV(-1)) } & -0.086983 & 0.075818 & 0.045013 & -0.218918 & -1.029522 & 0.027085 & -0.005477 \\
\hline & $(0.09522)$ & $(0.05837)$ & $(0.03418)$ & $(0.14403)$ & $(0.36081)$ & $(0.11562)$ & $(0.02169)$ \\
\hline & {$[-0.91346]$} & [1.29881] & {$[1.31692]$} & {$[-1.51996]$} & {$[-2.85338]$} & {$[0.23427]$} & {$[-0.25247]$} \\
\hline \multirow{3}{*}{ D(L_BLACKREV $(-2))$} & -0.081978 & 0.013478 & 0.067130 & -0.116780 & -0.965022 & 0.141435 & 0.008568 \\
\hline & $(0.09769)$ & $(0.05989)$ & $(0.03507)$ & $(0.14776)$ & $(0.37015)$ & $(0.11861)$ & $(0.02226)$ \\
\hline & {$[-0.83917]$} & {$[0.22506]$} & [1.91443] & {$[-0.79035]$} & {$[-2.60711]$} & {$[1.19244]$} & [0.38501] \\
\hline \multirow{3}{*}{ D(L_BLACKREV $(-3))$} & -0.007262 & -0.004182 & 0.066117 & 0.720327 & -0.877521 & 0.023723 & 0.007642 \\
\hline & $(0.10095)$ & $(0.06189)$ & $(0.03624)$ & $(0.15269)$ & $(0.38251)$ & $(0.12257)$ & $(0.02300)$ \\
\hline & {$[-0.07193]$} & {$[-0.06757]$} & {$[1.82461]$} & {$[4.71751]$} & {$[-2.29410]$} & {$[0.19354]$} & {$[0.33227]$} \\
\hline \multirow{3}{*}{$\mathrm{D}\left(\mathrm{L} \_\right.$MOBVREV $\left.(-1)\right)$} & -0.009977 & -0.026281 & -0.003991 & -0.044295 & -0.317477 & -0.012075 & 0.007681 \\
\hline & $(0.02995)$ & $(0.01836)$ & $(0.01075)$ & $(0.04531)$ & $(0.11350)$ & $(0.03637)$ & $(0.00682)$ \\
\hline & {$[-0.33308]$} & {$[-1.43127]$} & {$[-0.37121]$} & {$[-0.97770]$} & {$[-2.79728]$} & {$[-0.33201]$} & [1.12560] \\
\hline \multirow{3}{*}{ D(L_MOBVREV $(-2))$} & 0.037286 & -0.016320 & -0.006105 & -0.027980 & -0.122282 & -0.094500 & 0.002223 \\
\hline & $(0.03064)$ & $(0.01878)$ & $(0.01100)$ & $(0.04634)$ & $(0.11610)$ & $(0.03720)$ & $(0.00698)$ \\
\hline & {$[1.21690]$} & {$[-0.86885]$} & {$[-0.55510]$} & {$[-0.60374]$} & {$[-1.05328]$} & {$[-2.54023]$} & {$[0.31853]$} \\
\hline \multirow{3}{*}{ D(L_MOBVREV(-3)) } & 0.032435 & 0.025152 & 0.002516 & 0.036742 & 0.081902 & -0.065880 & 0.011638 \\
\hline & $(0.02834)$ & $(0.01737)$ & $(0.01017)$ & $(0.04286)$ & $(0.10738)$ & $(0.03441)$ & $(0.00646)$ \\
\hline & [1.14454] & [1.44784] & {$[0.24731]$} & {$[0.85720]$} & {$[0.76276]$} & {$[-1.91472]$} & {$[1.80274]$} \\
\hline
\end{tabular}


Continued

\begin{tabular}{|c|c|c|c|c|c|c|c|}
\hline \multirow{3}{*}{$\mathrm{D}\left(\mathrm{L} \_\right.$NEERREV $\left.(-1)\right)$} & 0.026175 & -0.059622 & -0.043177 & -0.054616 & 0.852531 & -0.138575 & -0.024359 \\
\hline & $(0.09763)$ & $(0.05985)$ & $(0.03504)$ & $(0.14767)$ & $(0.36993)$ & $(0.11854)$ & $(0.02224)$ \\
\hline & {$[0.26810]$} & {$[-0.99619]$} & {$[-1.23207]$} & {$[-0.36985]$} & {$[2.30458]$} & {$[-1.16903]$} & {$[-1.09516]$} \\
\hline \multirow{3}{*}{ D(L_NEERREV $(-2))$} & 0.147202 & -0.088689 & -0.075365 & -0.182021 & 0.247279 & -0.046536 & 0.003394 \\
\hline & $(0.09231)$ & $(0.05659)$ & $(0.03313)$ & $(0.13962)$ & $(0.34977)$ & $(0.11208)$ & $(0.02103)$ \\
\hline & [1.59465] & {$[-1.56725]$} & {$[-2.27454]$} & {$[-1.30368]$} & {$[0.70698]$} & {$[-0.41521]$} & {$[0.16137]$} \\
\hline \multirow{3}{*}{ D(L_NEERREV $(-3))$} & 0.183971 & -0.103579 & 0.019372 & -0.167545 & 0.064175 & 0.236578 & 0.011983 \\
\hline & $(0.09278)$ & $(0.05688)$ & $(0.03330)$ & $(0.14033)$ & $(0.35155)$ & $(0.11265)$ & $(0.02114)$ \\
\hline & [1.98284] & {$[-1.82109]$} & {$[0.58167]$} & {$[-1.19390]$} & {$[0.18255]$} & [2.10012] & {$[0.56690]$} \\
\hline \multirow{3}{*}{$\mathrm{D}\left(\mathrm{L} \_\mathrm{CPI}(-1)\right)$} & -0.864424 & 1.443441 & -0.264424 & 1.578868 & -1.526258 & -0.134282 & 0.385059 \\
\hline & $(0.50002)$ & $(0.30652)$ & $(0.17948)$ & $(0.75629)$ & $(1.89458)$ & $(0.60709)$ & $(0.11391)$ \\
\hline & {$[-1.72879]$} & [4.70907] & {$[-1.47329]$} & {$[2.08766]$} & {$[-0.80559]$} & {$[-0.22119]$} & [3.38033] \\
\hline \multirow{3}{*}{$\mathrm{D}\left(\mathrm{L} \_\mathrm{CPI}(-2)\right)$} & -0.602854 & 0.079116 & 0.357353 & 0.091734 & -4.063675 & 0.610740 & 0.077228 \\
\hline & $(0.59869)$ & $(0.36701)$ & $(0.21490)$ & $(0.90553)$ & $(2.26847)$ & $(0.72690)$ & $(0.13639)$ \\
\hline & {$[-1.00695]$} & {$[0.21557]$} & [1.66290] & {$[0.10130]$} & [-1.79137] & {$[0.84020]$} & {$[0.56622]$} \\
\hline \multirow{3}{*}{$\mathrm{D}\left(\mathrm{L} \_\mathrm{CPI}(-3)\right)$} & 0.765772 & -0.493218 & 0.082162 & -1.215918 & -3.756567 & -0.545176 & -0.162196 \\
\hline & $(0.62227)$ & $(0.38147)$ & $(0.22336)$ & $(0.94120)$ & $(2.35781)$ & $(0.75552)$ & $(0.14176)$ \\
\hline & [1.23061] & {$[-1.29294]$} & {$[0.36784]$} & {$[-1.29188]$} & {$[-1.59325]$} & {$[-0.72159]$} & {$[-1.14414]$} \\
\hline \multirow{3}{*}{$\mathrm{C}$} & 0.011998 & 0.000577 & -0.004359 & 0.008525 & 0.090475 & -0.000407 & 0.002584 \\
\hline & $(0.00639)$ & $(0.00392)$ & $(0.00229)$ & $(0.00966)$ & $(0.02420)$ & $(0.00775)$ & $(0.00145)$ \\
\hline & [1.87862] & {$[0.14736]$} & {$[-1.90167]$} & [0.88258] & [3.73882] & {$[-0.05246]$} & [1.77601] \\
\hline R-squared & 0.649710 & 0.919142 & 0.351099 & 0.720547 & 0.483544 & 0.317557 & 0.543531 \\
\hline Adj. R-squared & 0.532947 & 0.892189 & 0.134799 & 0.627396 & 0.311392 & 0.090076 & 0.391375 \\
\hline Sum sq. resids & 0.026363 & 0.009907 & 0.003397 & 0.060312 & 0.378492 & 0.038863 & 0.001368 \\
\hline S. E. equation & 0.019986 & 0.012252 & 0.007174 & 0.030229 & 0.075728 & 0.024266 & 0.004553 \\
\hline F-statistic & 5.564335 & 34.10189 & 1.623203 & 7.735267 & 2.808823 & 1.395970 & 3.572188 \\
\hline Log likelihood & 235.2511 & 278.8031 & 326.4392 & 198.4250 & 116.6932 & 217.9821 & 366.9016 \\
\hline Akaike AIC & -4.769688 & -5.748383 & -6.818858 & -3.942135 & -2.105465 & -4.381620 & -7.728127 \\
\hline Schwarz SC & -4.126557 & -5.105253 & -6.175727 & -3.299004 & -1.462334 & -3.738490 & -7.084996 \\
\hline Mean dependent & 0.007667 & 0.004269 & -0.001041 & 0.012095 & 0.021105 & -0.000531 & 0.004127 \\
\hline S. D. dependent & 0.029245 & 0.037314 & 0.007713 & 0.049523 & 0.091258 & 0.025439 & 0.005836 \\
\hline \multicolumn{2}{|c|}{ Determinant resid covariance (dof adj.) } & $9.44 \mathrm{E}-26$ & & & & & \\
\hline \multicolumn{2}{|c|}{ Determinant resid covariance } & $1.16 \mathrm{E}-26$ & & & & & \\
\hline \multicolumn{2}{|l|}{ Log likelihood } & 1773.308 & & & & & \\
\hline \multicolumn{2}{|c|}{ Akaike information criterion } & -36.05186 & & & & & \\
\hline \multicolumn{2}{|l|}{ Schwarz criterion } & -31.32625 & & & & & \\
\hline \multicolumn{2}{|l|}{ Number of coefficients } & 169 & & & & & \\
\hline
\end{tabular}

